On

\title{
Credit Risk Management of Jamuna Bank Limited
}

\section{Prepared For-}

Md. Mahmudul Huq

Senior Lecturer,

Faculty of Business,

ASA University Bangladesh.

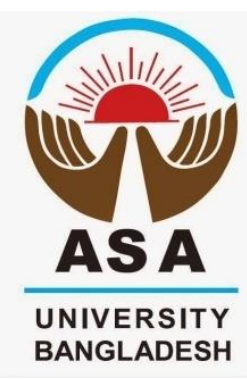

Prepared By-

Ruhul Amin

ID:111-12-0072

Batch: FIN 12 ${ }^{\text {th }}$ (A)

Dept. of Business Administration

ASA University Bangladesh.

Date of Submission: $5^{\text {th }}$ January, 2015 


\section{INTERNSHIP REPORT ON CREDIT RISK MANAGEMENT OF JAMUNA BANK LIMITED}




\section{$\underline{\text { Letter of Transmittal }}$}

$5^{\text {th }}$ January 2015 ,

To,

Md. Mahmudul Huq

Senior Lecturer

Faculty of Business

ASA University Bangladesh.

\section{Subject: Request for approval of Internship Report}

Dear Sir,

With the passage of time, I am student of ASA University Bangladesh standing on the other entity of my course completion, hence are finalized with my internship report naming as "Credit Risk Management of JBL". Vividly enough, my research comprises adequate endeavors. But no doubt, my contribution will be best evaluated on your sharp scale of acceptance \& analytical remarks. Consequently, I am submitting my report on your very concern. Hopefully, you will discover my well-researched, informative approach as a hallmark of hard work. Rather, in case of any further clarification or elaboration as to my report, I would welcome the opportunity to consult with you to explore how my findings could best meet your needs.

Thanking You.

With best regards,

Ruhul Amin

ID \# 111-12-0072

FIN 12 (A) (BBA) 


\title{
DECLARATION OF STUDENT
}

This is to notify that this report "Credit Risk Management of JBL." has been prepared as a part of my internship formalities. It is an obligatory part of our BBA program to submit an internship report. Moreover, I was inspired and instructed by my supervisor Mr. Md. Mahmudul Huq, Senior Lecturer to work on the mentioned topic.

\author{
Ruhul Amin \\ ID: 111-12-0072 \\ Batch No: FIN 12 (A) \\ Bachelor of Business Administration (BBA), \\ Major in Finance, \\ ASA University Bangladesh
}




\section{$\underline{\text { Supervisor's Certification }}$}

I hereby declare that the concerned internship report entitled "Credit Risk Management of

Jamuna Bank Limited” is an original work by Ruhul Amin, ID\# 111-12-0072, Major in Finance, Department of Business Administration, ASA University Bangladesh, completed this internship report under my supervision and submitted for the partial fulfillment of the requirement of the degree of Bachelor of Business Administration (BBA) at ASA University Bangladesh

Md. Mahmudul Huq

Senior Lecturer

Faculty of Business

ASA University Bangladesh. 


\section{ACKNOWLEDGEMENT}

I am Ruhul Amin and would like to express my heartiest gratitude to those who helped me all the way through to complete my internship report on "Credit Risk Management at Jamuna Bank Limited". At the very beginning, I want to thank almighty Allah, whose invible guidance helped me to complete this intern report.

I specially acknowledge my academic supervisor Mr. Md. Mahmudul Huq, Senior Lecturer of ASA University Bangladesh, for providing me all the necessary helps for the completion of this report. Without his regular monitoring, it was impossible to finish my report.

Secondly, I am very much grateful to Rehana Parvin, Faishal Ahmed, Abdulla-Al-Mamun, Salauddin Ahmed who helps me a lot. I would convey my special thanks to my parents whose inspirations have enabled me to complete this report. 


\section{EXECUTIVE SUMMARY}

Banks are exposed to five core risks through their operation, which are - credit risk, asset/liability risk, foreign exchange risk, internal control \& compliance risk, and money laundering risk. Among these risks management of credit risk gets most attention. Credit risk arises due to the possibility that the borrower may fail to repay the loan. Following the recent global financial crisis, which originated from poor management of credit risk, credit risk is the most discussed topic in banking industry. All commercial banks operating in Bangladesh are strictly regulated by Bangladesh Bank. Bangladesh Bank has provided a guideline for credit risk management. All banks try to comply with that guideline. Jamuna bank is no exception of this practice.

JBL has segregated the credit related activities. Marketing, preparation of credit proposal, other documentation, credit disbursement, credit monitoring etc are done at branch level. Credit administration and credit risk management related works are done at head office.

At branch level, branch managers act as Relationship Manager (RM) to explore/find new business opportunities. If a new business is located he informs Head of Corporate Division using a call report. Corporate Division shall examine the call reports and communicate their initial views to the Branch about the proposed business. If the views are positive, $\mathrm{HO}$ will direct the concerned RM to send a complete business proposal to Corporate Division. Then the Branch submits complete proposal to H.O. CRM examines the proposal from different angles of risk and compliance and communicate their views.

Then the proposal is sent to credit review committee by corporate division. CRM simply presents their observations. Credit Review Committee provides their views about the proposal which has to be approved by the M.D. corporate division may amend/change their proposal according to the recommendation of credit review committee. The Managing Director shall approve the facility if it is within power. If Board/EC approval is required, the Memo is to be signed by the Managing Director. After approval the CRM shall issue sanction advice enclosing documentation check list with a copy to credit Administration Division.

When a party approaches JBL for a loan, a loan proposal is prepared at branch level, which includes credit risk assessment report, credit risk grading report besides recommended amount of loan that can be disbursed. This proposal is sent to the Head Office for approval. If Credit Administration Department of Head Office sanctions the proposal then the amount is disbursed to that party. Monitoring the loan after disbursement is the branch's responsibility.

All loan applicants are required to submit financial statements of past three years. Relevant financial performance indicators are put into a spreadsheet to assess the credit risk. JBL has a credit policy guideline which is in line with the guideline provided by Bangladesh Bank. Different weights are given to different factors like industry profitability, company size, debt burden ratio, previous loan performance etc. 


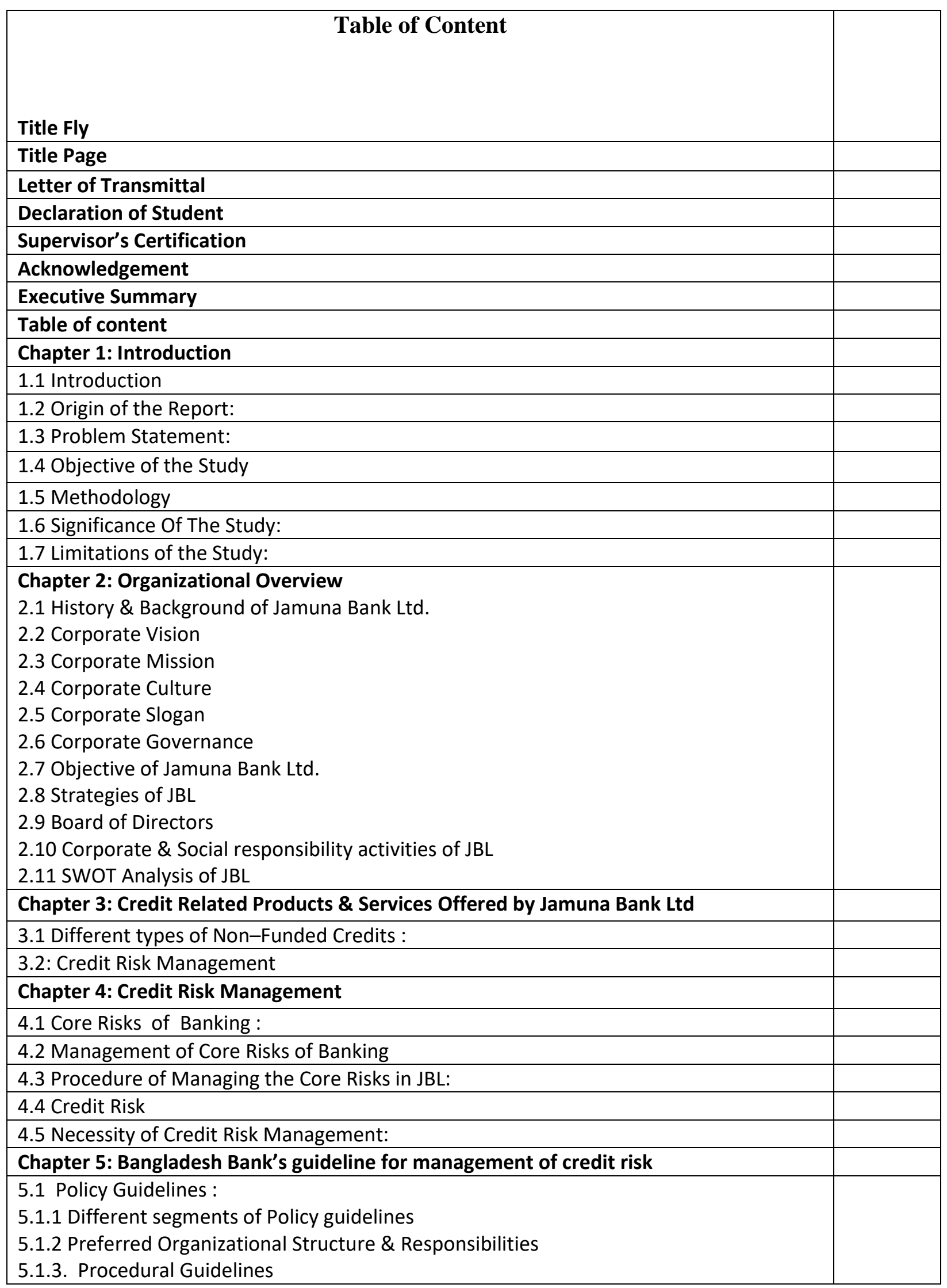


ABC Research Alert, Vol 4, No 1 (2016)

ISSN 2413-5224

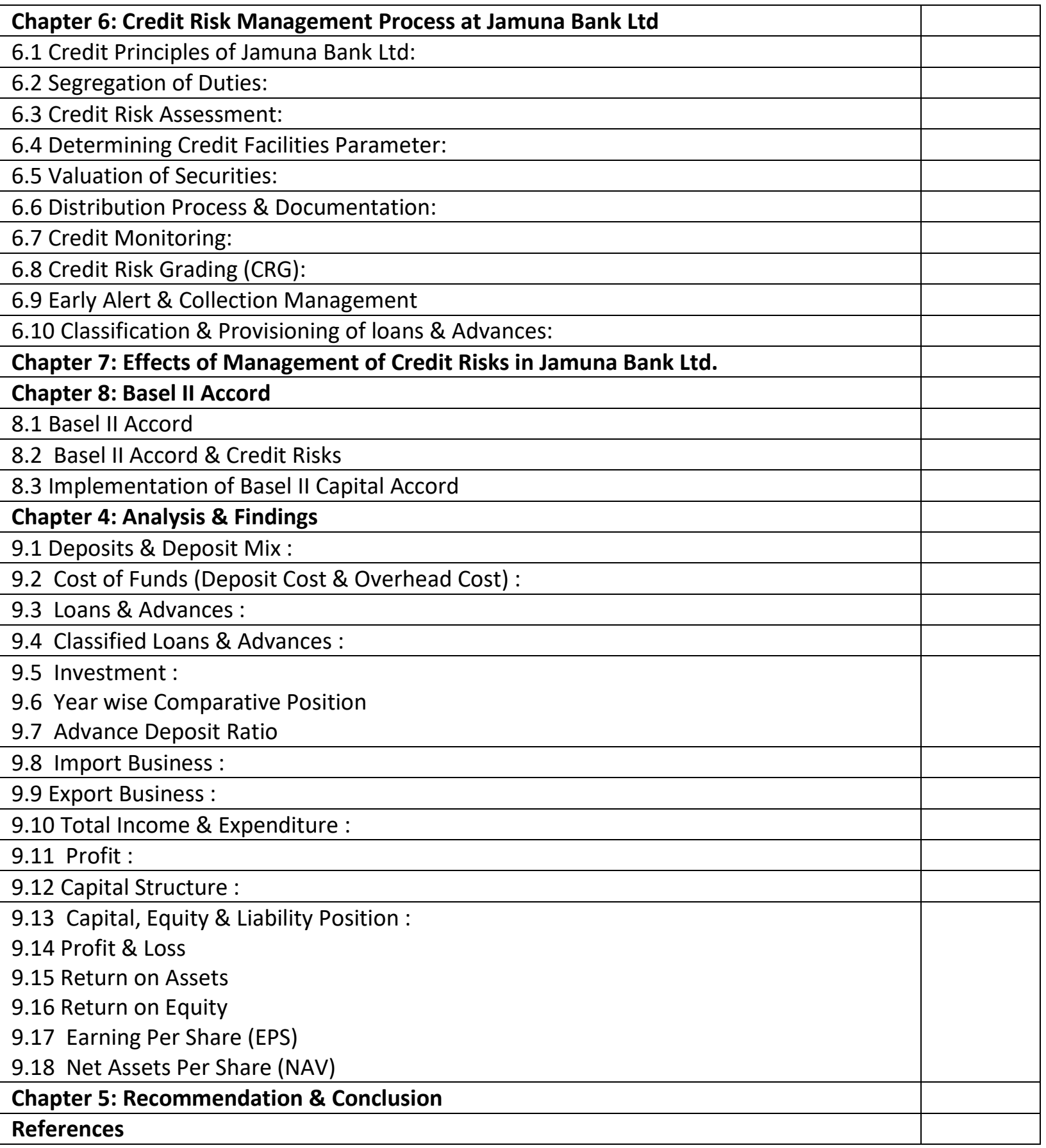


CHAPTER 1

INTRODUCTION 


\subsection{INTRODUCTION}

Jamuna Bank Ltd. is a third generation bank in Bangladesh. It provides commercial banking services in the Bangladesh. It is playing an important role to develop the business sector. The growth of this bank is very good. Its motto is to provide a prompt and quick service to the clients. Jamuna Bank Ltd. has implemented well structured online banking systems that make it easier to provide prompt services to the customer. The bank primarily engages in corporate banking, trade finance, project finance, retail banking, small enterprise finance, consumer finance, and syndication. Its range of service offerings include cash management services, payments and clearings, safe deposit locker services, employee benefits, collection services, treasury services, asset management, services and SWIFT for foreign trade.

\subsection{ORIGIN OF THE REPORT:}

As a prerequisite of obtaining Bachelor of Business Administration (BBA) degree from Business Administration, ASA University Bangladesh, every student has to go through an internship program. The author of the study is worked as intern at Jamuna Bank Limited, a well reputed private sector commercial bank. Under the supervision of Mr. MD. Mahmudul Huq, Senior Lecturer, ASAUB; the author has been assigned to prepare an internship report on "Credit Risk Management of Jamuna Bank Limited". This report is written to comply with that instruction.

\subsection{PROBLEM STATEMENT:}

The main function of the bank is borrowing money from the people by accepting deposits and lending them for development of trade, commerce, industry and agriculture. A Bank is thus a dealer of money and credit. Banks act as financial intermediaries between savers and investors. It is a profit seeking business concern as any other commercial or industrial organization.

The failure of the commercial banks mainly occurs due to bad loans that occur due to inefficient management of loans and advance portfolio. Credit portfolio is not only the Bank's asset but also a vital force of the Bank's success. Proper credit appraisal is the vital factor to reduce the default culture in the Banking industry. If the borrowers are assessed properly, possibility of default will be reduced.

Jamuna Bank Limited is one of the top ranked third generation banks in Bangladesh that provides short-term and long-term finance for business enterprises as well as to general people. This study covers credit risk management of Jamuna Bank Limited. 


\subsection{OBJECTIVES OF THE STUDY:}

General objective of this report is to examine overall credit risk management system of Jamuna Bank Limited.

Specific objectives of this report are -

- To analyze various credit policies of Jamuna Bank Limited.

- To examine the credit appraisal procedures followed by Jamuna Bank Limited.

- To study the control mechanisms followed by JBL for lending.

- To observe the overall asset quality of JBL.

- To recommend some suggestions for further development of JBL.

\subsection{METHODOLOGY:}

\subsubsection{Sources of Data:}

Both Primary and Secondary data have been used in preparing this report. The details of the sources of data are as follows:

- Primary Sources:

- Practical work exposure with Jamuna Bank Limited

- Face to face conversation / Interview with the Bank Officials

- Observations

- Secondary Sources:

- Annual Report of Jamuna Bank Limited

- Credit Operational Manual

- Training materials of the Bank

- Periodicals published by Bangladesh Bank

- Various books, journals, articles etc.

- Web Sites. 


\subsubsection{Scope of the Study:}

Risk is the chance that an investment's actual return will be different than expected. This includes the possibility of losing some or all of the original investment. It is usually measured by calculating the standard deviation of the historical returns or average returns of a specific investment. A fundamental idea in finance is the relationship between risk and return. The greater the amount of risk that an investor is willing to take on, the greater the potential return. The reason for this is that investors need to be compensated for taking on additional risk.

All credit extension must comply with the requirements of Bank's Memorandum and Article of Association, Banking Company's Act, Bangladesh Bank's instructions, other rules and regulation as amended from time to time. Loans and advances shall normally be financed from customer's deposit and not out of temporary funds or borrowing from other banks. The bank shall provide suitable credit services for the markets in which it operates. It should be provided to those customers who can make best use of them. The conduct and administration of the loan portfolio should contribute within defined risk limitation for achievement of profitable growth and superior return on bank capital. Interest rate of various lending categories will depend on the level of risk and types of security offered.

By analyzing the total risk, some indexes have taken to analyze only the credit risk of Jamuna Bank Limited except other risks e.g. market risk, operational risk etc. The credit risk has been taken into consideration for analyzing because of the fact that it is our related matter. For that purpose firstly the deposit of the branch is analyze. Then calculation of the cost of deposit is needed, which helps to set the lending rate. The author has analyzed determination of lending rate, the advance deposit ratio, yearly comparison of Export \& Import business, Income \& Expenditure and the profit of Jamuna Bank Limited. Thus samples of the full set of data have been taken to analyze the total scenario of risk management of Jamuna Bank Limited. Sample of data is taken such a way to ensure that the sample reflects over the full dataset and gives a detail overview about the risk of credit management. For analyzing the credit risk Balance sheet, Income Statement and Cash Flow Statement of Jamuna Bank Limited from year 2010 to 2013 have been taken

\subsection{SIGNIFICANCE OF THE STUDY:}


In modern banking concept one of the most important functions of a Bank or Financial Institute is "Management of Credit Risks". Risk is inherent in all aspects of commercial operations. However for Banks Credit risk is an essential factor that needs to be managed.

The present economic state of Bangladesh demands immediate development of the efficient and strong financial institutions. Banking sector has lot of areas to improve upon. One of the measures to improve this condition is to develop and design the effective system for Management of Credit Risks which requires continuous study and research thereupon.

\subsection{LIMITATIONS OF THE STUDY:}

Credit risk management is a vast area for studying. Different departments participate in credit risk management. The author had limited exposure to all those departments during his internship period. Therefore not all information or observation presented throughout the report is from first hand experience. 


\section{CHAPTER 2}

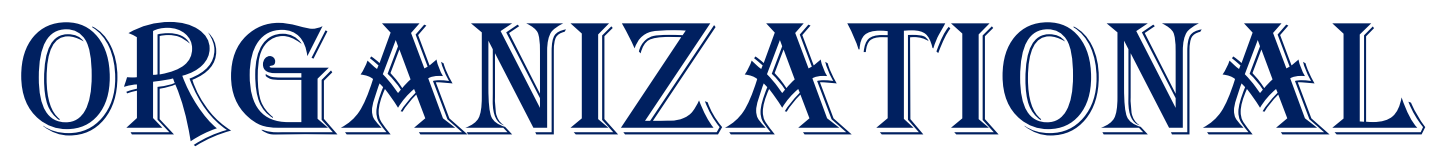

OVERVIEW 
Jamuna Bank Ltd. (JBL) is a Banking Company registered under the Bank Companies Act, 1991 and incorporated as Public Company limited by Shares under the Companies Act, 1994 in Bangladesh. The Bank started its operation from $3^{\text {rd }}$ June 2001 as a scheduled Bank. JBL is the $3^{\text {rd }}$ generation commercial bank in Bangladesh.

JBL came into being as a highly capitalized new generation Bank started its operations with an Authorized Capital and Paid-up Capital of Tk.2424.00 million and Tk.1313.00 million respectively.

$\mathrm{JBL}$, the only Bengali named private commercial bank was established by a group of winning local entrepreneurs conceiving an idea of creating a model banking institution with different outlook to offer the valued customers, a comprehensive range of financial services and innovative products for sustainable mutual growth and prosperity. The sponsors are reputed personalities in the filed of trade, commerce and industries.

The Bank is being managed and operated by a group of highly educated and professional team with diversified experiences in finance and banking. A team of highly qualified and experienced professionals headed by the Managing Director of the Bank who has vast banking experience operates bank and at the top there is an efficient Board of Directors for making policies. Earnest and prudent involvement of the best management team in all tires of the Bank has brought the best out of the Bank. The Management of the bank constantly focuses on understanding and anticipating customer's needs.

The scenario of banking business is changing day by day, so the bank's responsibility is to devise strategy and new products to cope with the changing environment. JBL has already achieved tremendous progress within only ten years. The bank has already ranked at top of the quality service providers $\&$ is known for its reputation.

$\mathrm{JBL}$ is now trying to widen its periphery by targeting all the potential sectors. With an extensive range of financial products and services the bank is committed to provide high quality financial services/products to its valued clients. JBL also aims to contribute to the growth of GDP of the country through stimulating trade \& commerce, accelerating the pace of industrialization, boosting up export, creating employment opportunity for the educated youth, alleviating poverty, raising standard of living of limited income group and expediting over all sustainable socio-economic development of the country.

To keep pace with time and in harmony with national and international economic activities and for rendering all modern services, JBL, as a financial institution automated all its branches with online computer network in accordance with the competitive commercial demand of time. Moreover, considering its forthcoming future the infrastructure of the Bank is being upgraded whenever felt necessary. 
Since its inception the Bank's footprint has grown to 96 branches across the country and the customer base has expanded to 580,069 depositors and 312,100 borrowers as on 30th November, 2014. The expectation of all class businessman, entrepreneurs and general public is much more to JBL. Keeping the target in mind the bank has taken preparation to open new branches in coming months of 2015-16.

JBL undertakes all types of banking transactions to support the development of trade and commerce of the country. The JBL's services are also available for the entrepreneurs to set up new ventures and BMRE of industrial units.

Now JBL is on line to establish trade and communication with the premier international banking companies of the world. As a result JBL is able to have a global footprint. The Bank has arrangement with widespread money transfer service agency "Money Gram". It has a full time arrangement for speedy transfer of money all over the world.

Banking is not only a profit-oriented commercial institution but it has a public base and social commitment. Admitting this true JBL is going on with its diversified banking activities. JBL offers different types of Corporate and Personal Banking Services involving all segments of the society within the purview of rules and regulations laid down by the Central Bank and other regulatory authorities. JBL introduced different types of Savings Schemes, Consumer's Credit Scheme, Housing Loan, different types of SME Loan facilities to combine the people of lower and middle-income group.

As regards mobilization of the Bank's deposit, utmost importance is attached for mobilization of stable, low and no-cost deposit so that proper liquidity could be maintained and maximum deployment of fund could be made avoiding mismatching of fund.

As regards extending Credits, all proposals are thoroughly perused, meticulously scrutinized and processed complying with Credit norms.

JBL has provided $\mathbf{Q}$-cash Debit and Credit Card that has gained good market reputation. Being inspired by market potential the Bank has already introduced VISA Card in the market in 2013.

Inspired by its social obligation and commitment and responsibility, JBL has formed a Foundation on its own guardianship named JBL Foundation inaugurated in 2013 so that some social welfare activities can be rendered to the society besides banking business. The Bank has started Scholarship Program to the meritorious but underprivileged students. 
Besides, with a view to develop the human resources professionally the Bank has established a Library wherein all sorts of books, journals including the professional books are available so that the officers and executives can sharpen and update their knowledge.

At present the Bank has real-time Online banking branches (of both Urban and Rural areas) network throughout the country having smart IT-backbone. Besides traditional delivery points, the bank has ATMs of its own, sharing with other partner banks and consortium throughout the country.

The operation hour of the Bank is 10:00 A.M. To 6:00 P.M. from Sunday to Thursday with transaction hour from 10:00 A.M. to 4:00 P.M. The Bank remains closed on Friday, Saturday and government holidays.

\subsection{CORPORATE VISION:}

To become a leading banking institution and to play a pivotal role in the development of the country through best application of modern information technology in business activities, offering high standard clientele services and proper coordination of high quality assets is the core of the vision.

\subsection{CORPORATE MISSION:}

The Bank is committed to satisfying diverse needs of its customers through an array of products at a competitive price by using appropriate technology and providing timely service so that a sustainable growth, reasonable return and contribution to the development of the country can be ensured with a motivated and professional workforce potential. With a view to achieving commercial objectives of the Bank, the sincere and all out efforts stay put unabated. Respected clients and shareholders are attracted to it for its transparency, accountability, social commitments and high quality of clientele services.

\subsection{CORPORATE CULTURE:}

Employees of JBL share certain common values that help to create a JBL Corporate culture.

- The client comes first.

- Search for professional excellence.

- Openness to new ideas and new methods to encourage creativity.

- Quick but proper decision making.

- Flexibility and prompt response.

- A sense of professional ethics. 


\subsection{CORPORATE SLOGAN:}

"Your Partner for Growth."

\subsection{CORPORATE GOVERNANCE:}

The organizational structure and corporate governance of JBL reflect the determination to establish, sustain and increase its strength for a strong base as a customer-oriented bank with a transparent management.

\subsection{OBJECTIVES OF JBL:}

The following objectives are set for JBL:

- To earn and maintain CAMEL Rating "Strong".

- To establish relationship banking and improve service quality through development of Strategic Marketing Plans.

- To remain one of the best banks in Bangladesh in terms of profitability and assets quality.

- To introduce fully automated systems through integration of information technology.

- To ensure an adequate rate of return on investment.

- To keep risk position at an acceptable range (including any off balance sheet risk).

- To maintain adequate liquidity to meet maturing obligations and commitments.

- To maintain a healthy growth of business with desired image.

- To maintain adequate control systems and transparency in procedures.

- To develop and retain a quality work-force through an effective human Resources Management System.

- To ensure optimum utilization of all available resources.

- To pursue an effective system of management by ensuring compliance to ethical norms, transparency and accountability at all levels.

\subsection{STRATEGIES OF JBL:}

The strategies of JBL are as follows:

- To manage and operate the Bank in the most efficient manner to enhance financial performance and to control cost of fund.

- To strive for customer satisfaction through quality control and delivery of timely services.

- To identify customers' credit and other banking needs and monitor their perception towards our performance in meeting those requirements.

- To review and update policies, procedures and practices to enhance the ability to extend better service to customers. 
- To train and develop all employees and provide them adequate resources so that customers' needs can be reasonably addressed.

- To promote organizational effectiveness by openly communicating company plans, policies, practices and procedures to employees in a timely fashion.

- To cultivate a working environment that fosters positive motivation for improved performance.

- To diversify portfolio both in the retail and wholesale market.

- To increase direct contact with customers in order to cultivate a closer relationship between the bank and its customers

\subsection{BOARD OF DIRECTORS:}

The Board of Directors is the supreme body of the Bank. The Board of Directors consists of 14(fourteen) members, out of which 13(thirteen) members are elected from the shareholders and the remaining member is the Managing Director who is appointed as the Chief Executive Officer of the Bank.

\section{The Present Board of Directors of the Bank are}

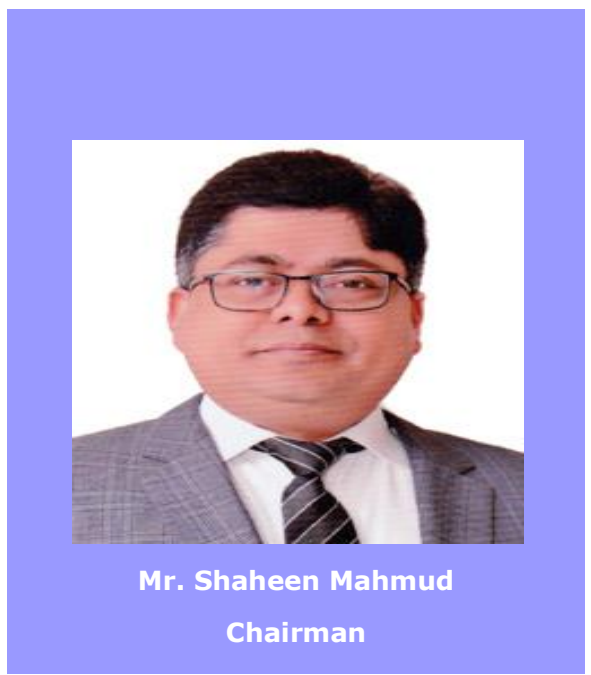

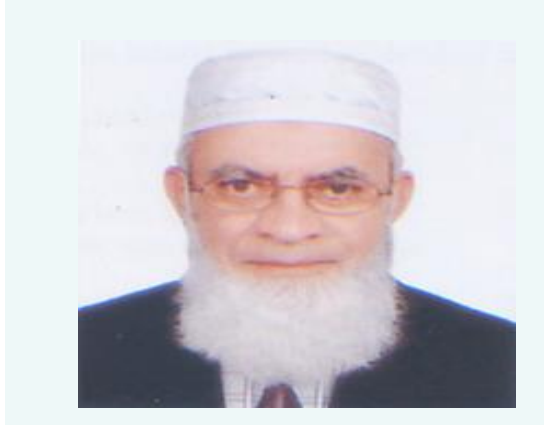

Engr. A. K. M. Mosharraf Hussain Director

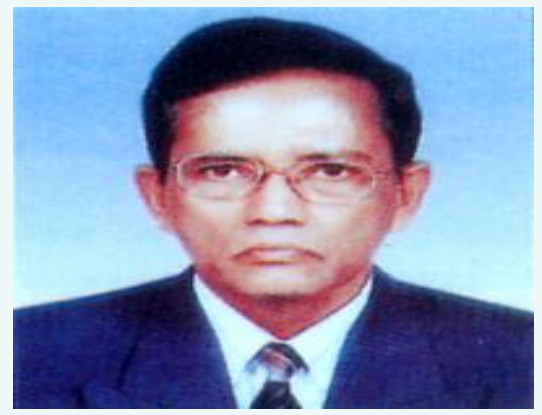

Engr. Md. Atiqur Rahman Director

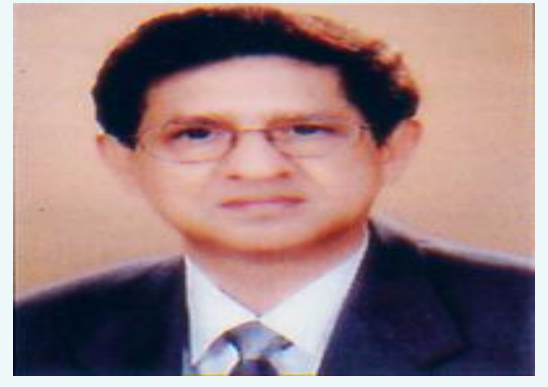

Mr. Golam Dastagir Gazi, Bir Protik Director 


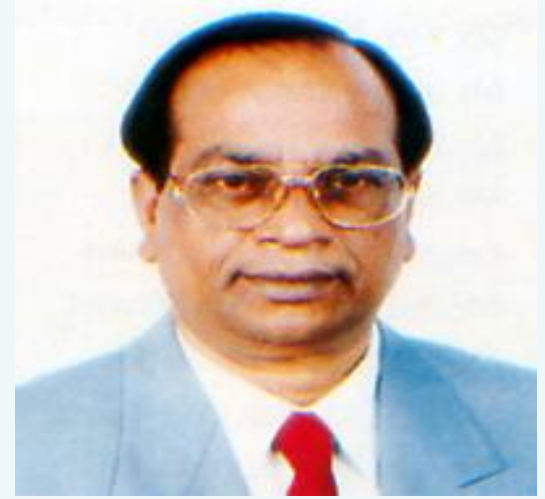

Mr. Fazlur Rahman

Director

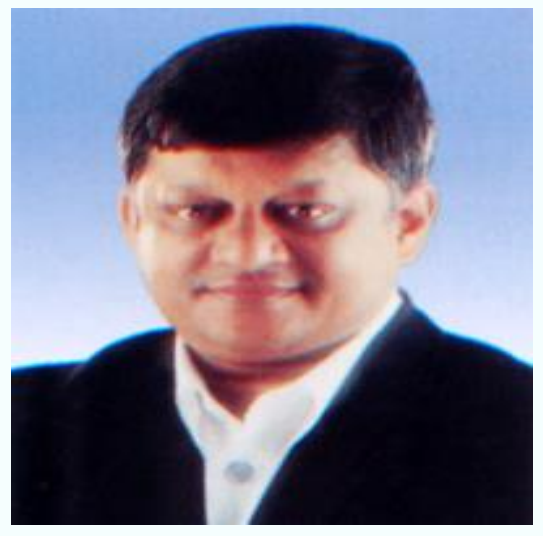

Mr. Sakhawat, Abu Khair

Mohammad

Director

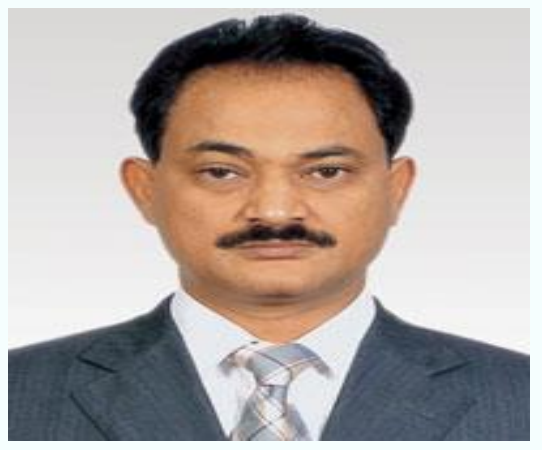

Mr. Md. Mahmudul Haque Director

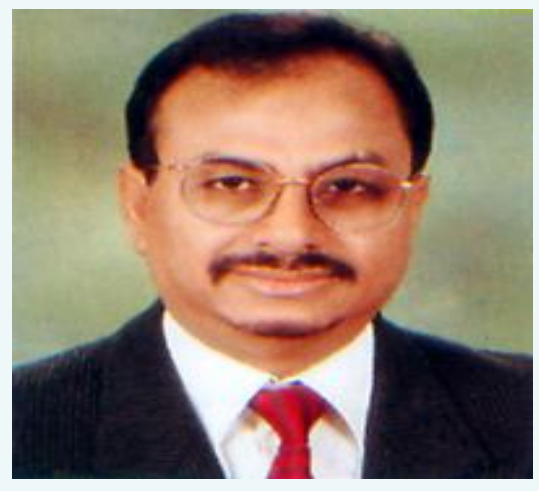

Al-Haj Nur Mohammed

Director

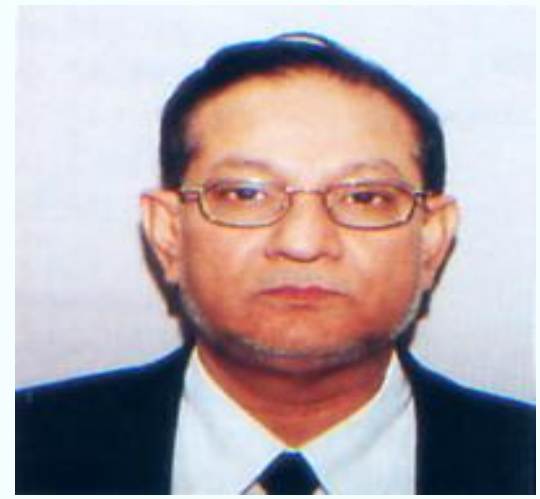

Al-haj Md. Rezaul Karim Ansari

Director

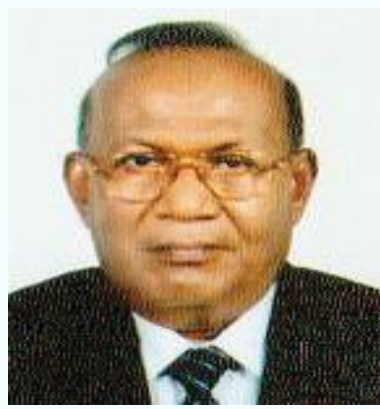

Mr. Kanutosh Majumder Director

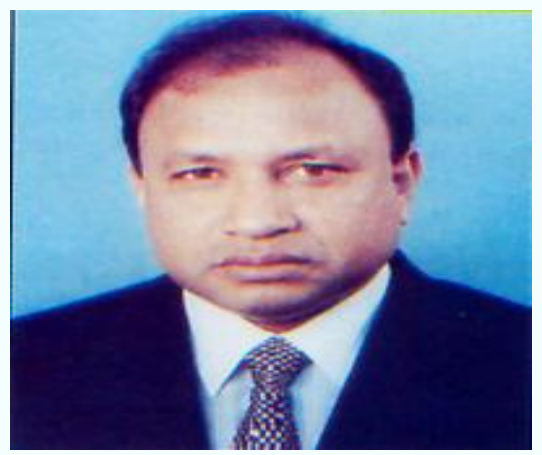

Mr. Md. Tajul Islam Director

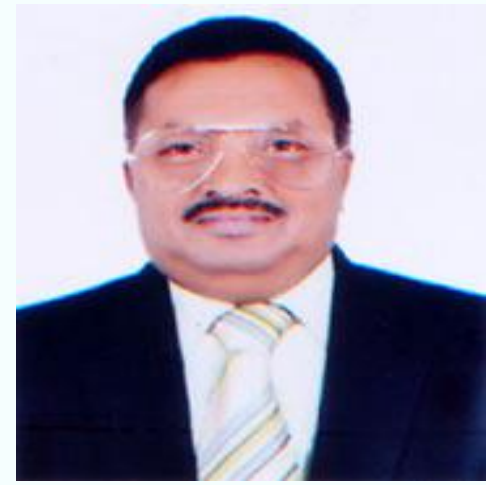

Mr. Md. Belal Hossain Director

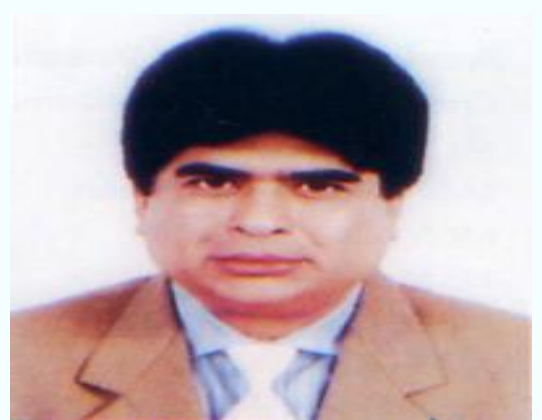

Mr. Md. Sirajul Islam Varosha Director 


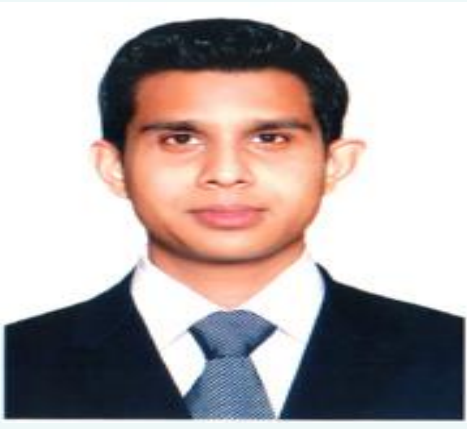

Mr. Gazi Golam Murtoza Director

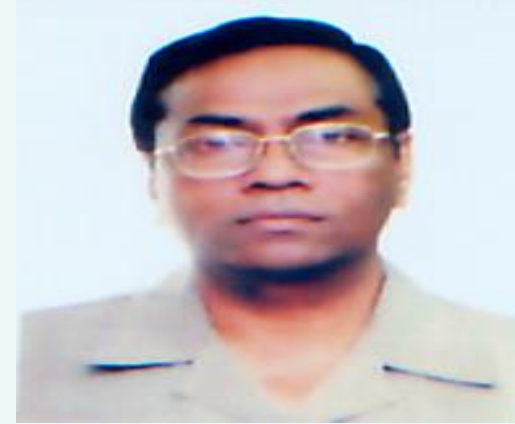

Mr. A. S. M. Abdul Halim Independent Director

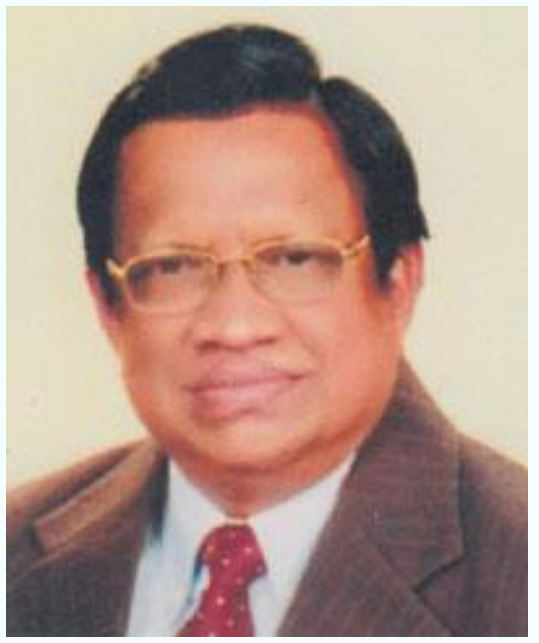

Mr. Md. Rafiqul Islam Independent Director

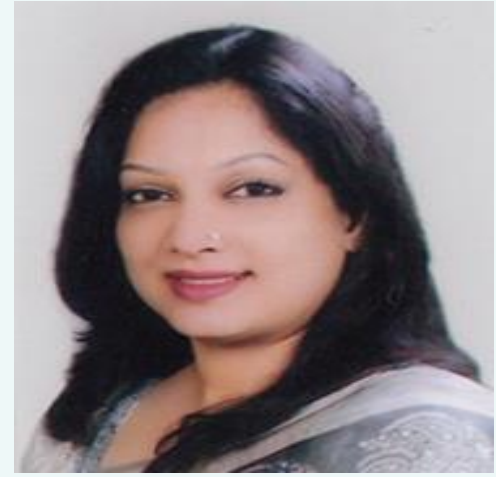

Mrs. Tasmin Mahmud

$$
\text { Director }
$$

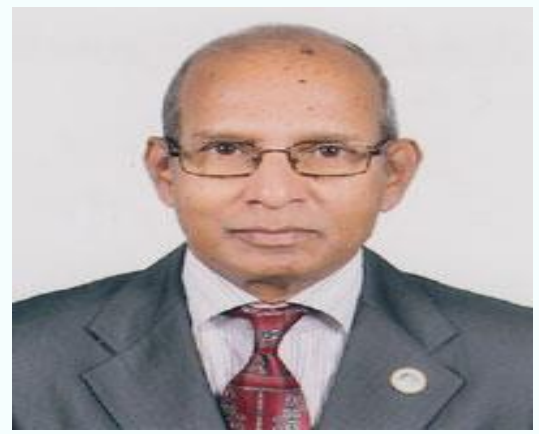

Mr. Narayan Chandra Saha Independent Director

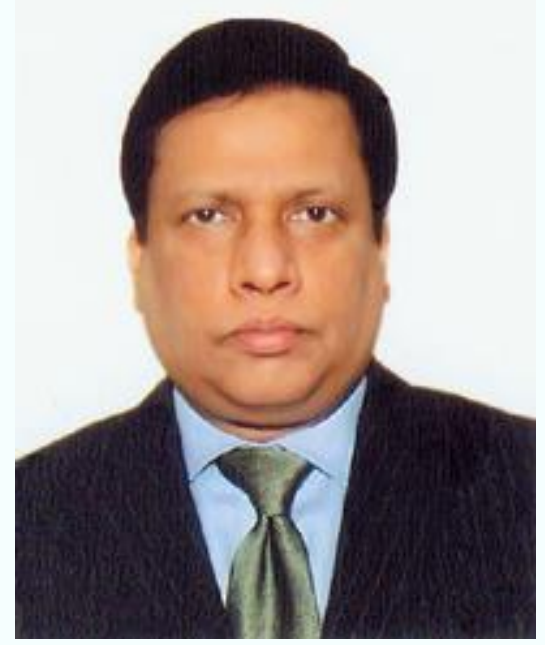

Mr. Shafiqul Alam

Managing Director

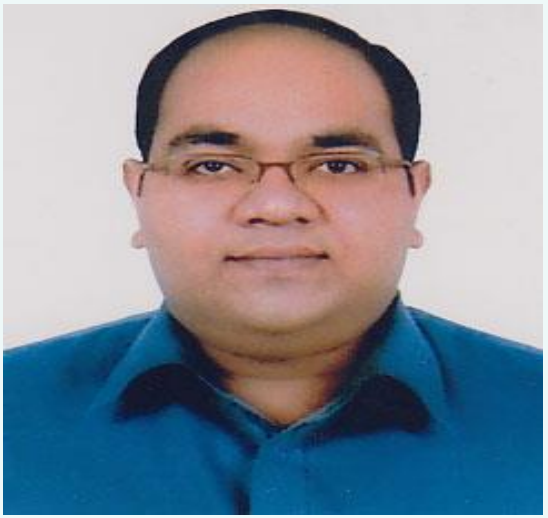

Mr. Md. Hasan

Director

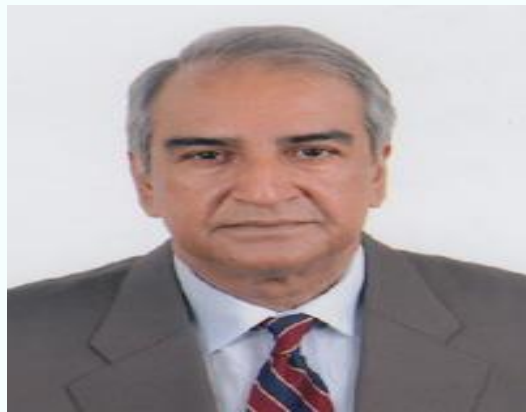

Mr. Chowdhury Mohammad Mohsin

Independent Director

\subsection{CORPORATE SOCIAL RESPONSIBILITY (CSR) ACTIVITIES OF JBL:}


JBL tries its best to fulfill its commitment to the society. JBL has a strong footprint in the arena of CSR activities which is overseen by the senior management. JBL has established Jamuna Bank Foundation (JBF) to manage its CSR activities.

Since its inception JBF is a strong advocate of anti-drug campaign. Throughout the year JBF has arranged numerous seminars, symposiums, anti-drug rallies all over the country. JBF has established a drug rehabilitation center.

$\mathrm{JBL}$ recognizes the fact that sports is the best way to uphold national pride and mobilize the youth towards enlightened path. JBL was the co-sponsor of 11th South Asian Games held from January 29, 2010 to February 9, 2010. For this purpose JBL paid Tk. 50 lacs to Bangladesh Olympic Association, arranger of the event. The event was observed by more than a billion viewers from the sub-continent. Several head of the states of this region attended the opening and closing ceremony.

JBF has always extended its helping hand to the victims of natural disasters. A severe category 5 cyclone named Aila struck the south-western shoreline of the country on may 25, 2009. According to government statistics at least 330 people were dead, 8208 were missing, and at least 1 million people were left homeless. Total damage was approximated to be around $\$ 40.7$ million. JBF was quick to response. JBF immediately mobilized a relief team and distributed foods, medicine, and blankets to Aila victims.

JBF has taken initiative to build an old home in Keranigonj. With the help of many generous locals the construction of the 10 storied building is going full swing. Helpless and alone people passing their golden age will be able to stay in a healthy, cheerful environment at a minimal cost. Poor senior citizens will have free of cost residence and medical care.

Educated and trained workforce is real human resource to the country. JBF always provide scholarships to needy meritorious students. JBF also provides financial aid to improve infrastructural facilities of schools in rural areas. JBF has established 9 vocational training institutes in different places of the country. After receiving training from these institutes many poor men and women have managed to become financially self-sufficient.

\subsection{SWOT ANALYSIS FOR JAMUNA BANK LIMITED:}

SWOT refers to an organization's strength, weakness, opportunities and threats. The underlying assumption of a SWOT analysis is that managers can better formulate a successful strategy after they have carefully reviewed the organization's strengths and weakness in the light of threats and opportunities presented by the environments. A right strategy can turn fledging organization into a successful one, whereas a wrong strategy could lead to a disaster. SWOT analysis emphasizes that organizational strategies must result a good fit between the organization's internal and external environments.

Some significant factors of Jamuna Bank Limited are presented below for SWOT Analysis: 


\section{Strengths}

- As a third generation bank, Jamuna Bank Limited has a very good credit portfolio in comparison of other third generation banks and also first and second generation banks.

- Robust IT infrastructure that helps to cope with modern techniques and facilities like real-time online banking, SMS banking, debit card \& credit card booth facilities.

- More efficient human resources \& competitive remuneration packages.

- All the branches of Jamuna Bank Limited situated in commercially important places through out Bangladesh.

- Jamuna Bank is the only bank in Bangladesh that has agreement with Bangladesh Postal Services regards to inflow remittance quickly to all over Bangladesh.

- Jamuna Bank Limited is Authorized Primary Dealer of Government Treasury Bonds \& Bills, approved by Bangladesh Bank.

\section{Weakness}

- $\quad \mathrm{JBL}$ is yet to establish itself as a brand

- Jamuna Bank Limited has loan portfolio on very few sectors.

- Customer perception about the bank or its service is not satisfactory

\section{Opportunities}

- $\quad$ Plenty of unexplored geographical territory where JBL can open branches.

- Jamuna Bank Limited has given emphasis on SME segment and going to open SME center all over the Bangladesh.

- Jamuna Bank Foundation can play a vital role in CSR activities that increase the image of the bank.

\section{Threats}

- $\mathrm{JBL}$ is operating in an extremely competitive sector. It looses customers to other banks.

- Global market recession.

- Political instability. 


\section{CHAPTER 3}

\section{CREDIT RELATED PRODUCTS \& SERVICES OFFERED BY JBL}




\section{- Cash Credit (Hypothecation) limit :}

Advances allowed to the business concerns for trading purpose or to the industries to meet up the working capital requirements against hypothecation of stocks as primary security fall under this type of lending. It is a sort of continuous credit wherein customers can transact in the account all through within the valid period. This type of credit is renewable after its expiry.

\section{- Cash Credit (Pledge) limit :}

It is financial accommodation to business concerns for trading purpose or to industries as working capital against pledge of stocks as primary security. It is also a continuous credit similar to the above.

\section{- Different types Over Draft facilities :}

JBL extended different types of Over Draft facilities to different individuals/ organizations like SOD (General), SOD (FDR), SOD (Financial Obligation), SOD (Work Order), SOD (Pay Order), etc. Out of those SOD (Gen.) is very much similar to C.C.(Hypo.) except Hypothecation of Stocks. SOD (FDR) is extended against lien on FDR that may be issued either by any branch of JBL or by other Bank(s). SOD (F.O.) is extended against lien on different types of Deposit under different schemes. On the other hand, SOD (W.O.) is extended against Assignment of Work order(s) for execution of concerned works. SOD (P.O.) is extended for participating in the Bids as invited by different work giving agencies.

Fig 3.1: Different types over draft facility by JBL

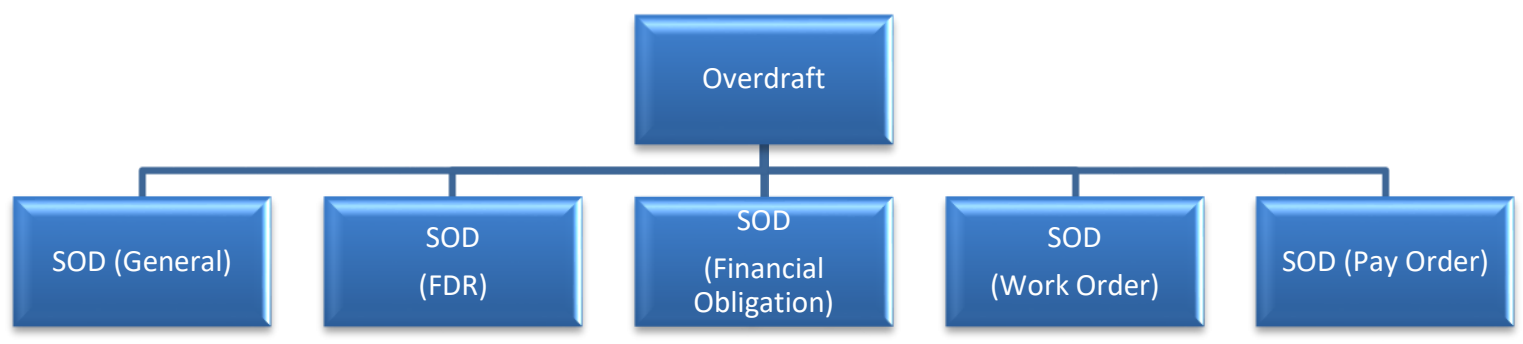

\section{- Term Loan :}

Term loans are allowed for a specific purpose but for a definite period. Term Loan is generally repayable by installments on monthly/ quarterly/ half-yearly basis. As per the length of the loan repayment period Term loans are divided in three categories i.e. Short term, Medium term and Long term. JBL provides Term Loans in different forms based on the purpose of the loan such as 
Loan (General), House Building Loan (Commercial), House Building Loan (General), House Building Loan (Staff), etc.

Fig 3.3: Different typed of term loan provided by JBL

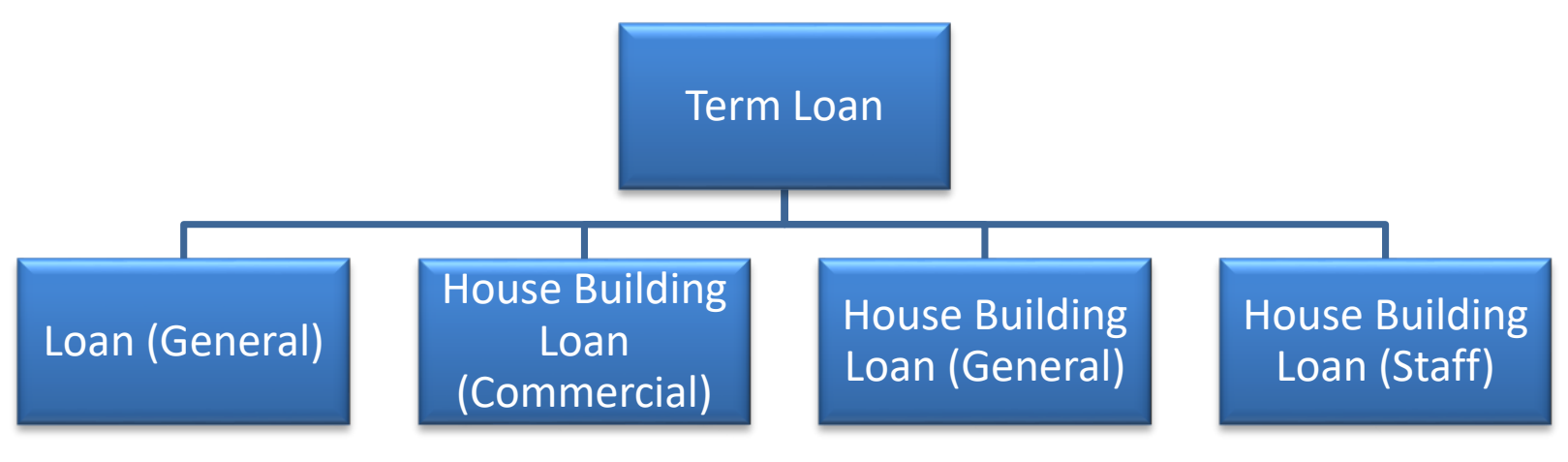

- Funded Credits Related to International Trade Finance :

International Trade forms the major business activity undertaken by JBL. The Bank with its worldwide correspondent network and close relationships with key financial institutions provides an extensive trade services network to handle the transactions efficiently.

The key branches of the Bank in Dhaka, Chittagong, Sylhet and Naogaon are staffed by personnel experienced in International Trade Finance. These offices are the focal point for processing import and Export transactions for both small and large corporate customers. JBL offers a complete range of Trade Finance services. The professionals are working to develop solutions tailored to meet the customer's requirements, through mobilizing full range of trade services locally, and drawing on the global resources. The Bank can offer professional advice on all aspects of International Trade requirements.

To provide International Trade related services JBL has established Correspondent Banking relationship with 336 locations of 106 world reputed Banks in more than 100 countries.

JBL provides all types of Funded Credits in connection with Foreign/International Trade. Foreign Trade related Funded Credits can be divided into two broad categories i.e. Post-Import Funded Credits and ii. Export \& Post-Export Funded Credits.

i. Post-Import Funded Credits are Loan against Trust Receipt (LTR), Loan against Imported Merchandise (LIM), etc. 
ii. Export \& Post-Export Funded Credits are Packing Credit (PC), Negotiation and Purchase of Export Bills (FDBP), Discounting Bill of Exchange (LDBP), etc.

Fig 3.3: Different Foreign Trade Related Funded Credits extended by JBL

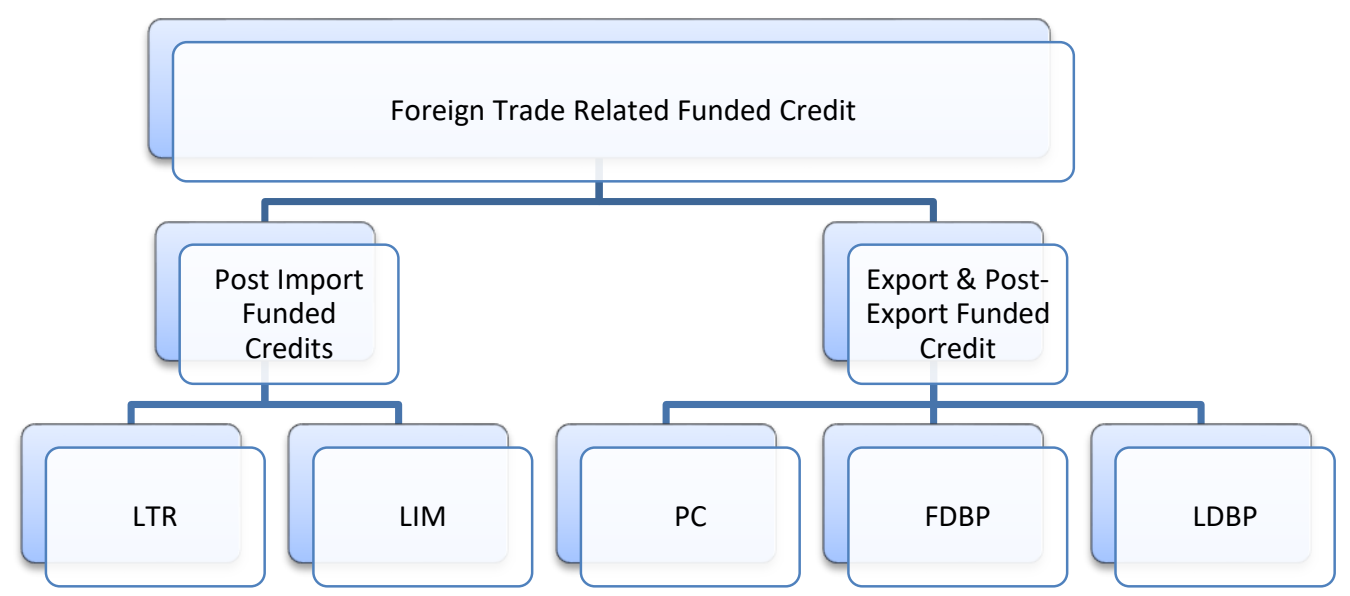

\section{Agricultural Credit:}

JBL provides credits for Agro Industries at a concession rate of interest.

\section{- Industrial Credit :}

JBL offers a complete range of advisory, financing and operational services to its corporate client groups combining trade, treasury, investment and transactional banking activities in one package. Corporate Banking business envelopes a broad range of business.

\section{- Lease Finance :}

Lease means a contractual relationship between the owner of the asset and its user for a specified period against mutually agreed upon rent. The owner i.e. the Bank is called the Lessor and the user i.e. the customer is called the Lessee. Lease finance is one of the most convenient sources of financing of assets viz. machinery, equipment vehicle, etc.

The user of the assets i.e. Lessee is benefited through tax advantages, conserving working capital and preserving debt capacity. Moreover, Lease is an off-balance sheet item i.e. lease amount is not shown in the balance sheet of the lessee and does not affect borrowing capacity. Leasing enables the lessee to avail the services of a plant or equipment without making the investment or incurring debt obligation. The Lessee can use the asset by paying a series of periodic amounts called "lease payment" or "lease rentals" to the owner of the asset at the predetermined rates and generally in advance. The payments may be made monthly or quarterly.

JBL the highly capitalized private Commercial Bank in Bangladesh has introduced lease finance to facilitate funding requirement of valued customers and growth of their business houses. 
JBL lease facility is extended to the items like Industrial Machinery, Luxury bus, Mini bus, Taxi cabs.

\section{Leased items:}

Vehicles like Luxury Bus, Mini bus, Taxi Cabs, Cars, Pick-up, CNG three wheeler, etc.

Industrial Machinery \& Equipment.

( Medical Equipment.

$\rightarrow$ Machinery for Agro-based Industry.

$\rightarrow$ Construction Equipment.

Office Equipment.

( Generators, Lifts \& Elevators for commercial place.

$\rightarrow$ Sea or River Transport.

$\rightarrow$ Computer for IT Education Center.

\section{Maximum Limit: $\quad$ up to $70 \%$ of acquisition cost.}

\section{- SME Credit Scheme :}

At present Small \& Medium Enterprise (SME) Credit is a very important product of banking. After a long while since the independence small and medium entrepreneurs of our country were overlooked in the banking sector as they do not have enough property to provide as collateral security to the commercial banks. But, this group is striving entrepreneurs, who cannot pursue their financial uplift due to financial constraint. On the other hand, the role of Small and Medium Enterprises is very crucial in the economic development of the country. SME plays the vital role in employment generation particularly self-employment by making significant contribution to the GDP. With this end in view, SME Credit concept has been introduced recently in the banking sector of our country in order to promote and to boost up the potentials of such small and medium entrepreneurs.

Being a socially committed bank JBL has introduced SME Credits with wide range of diversified products under its SME Scheme with a view to emancipate the grass-roots level to their economic height and to make profit by serving the interest of the missing small and middle groups.

The minimum and maximum exposures of the Bank on a single Small or Medium Enterprise are within the range of Tk.2.00 Lac to Tk.50.00 Lac respectively. In order to facilitate the growth of smaller loans, JBL extends security free loans below Tk.10.00 Lac. 
Fig 3.4: The products of JBL under SME Credit Scheme

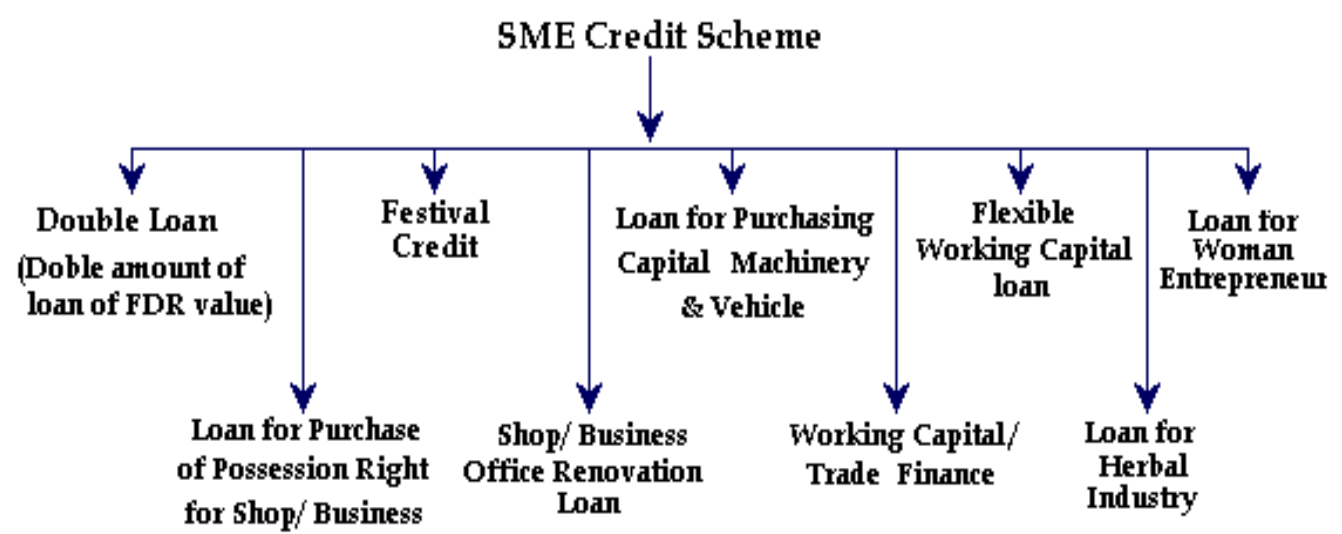

Retail

\section{Credit Products :}

JBL offers wide range of diversified Retail Credit products, which will facilitate to improve the standard of living of the country.

Fig 3.5: The Retail Credit Products of JBL

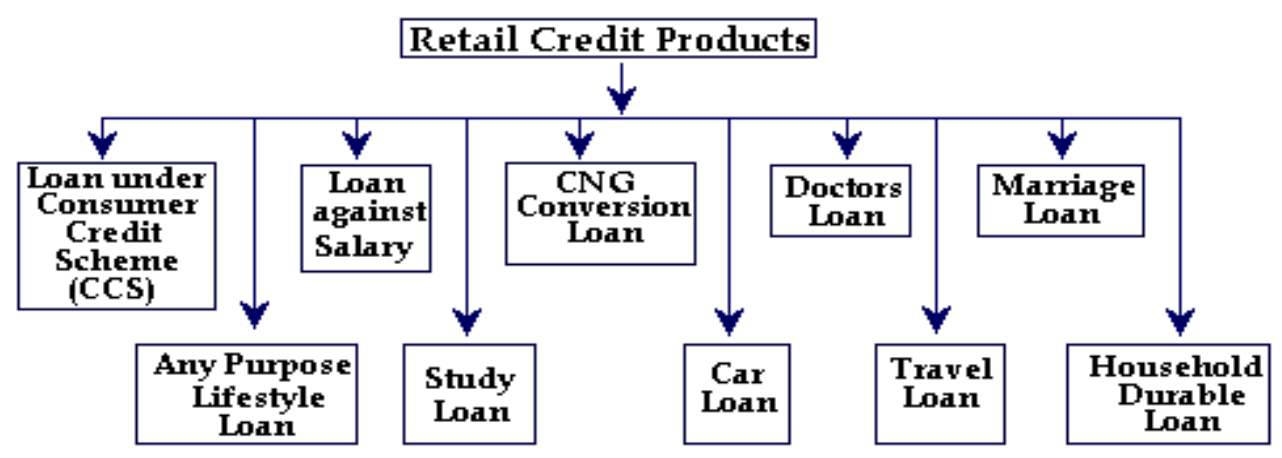

\subsection{DIFFERENT TYPES OF NON-FUNDED CREDITS:}

Non-Funded Credits related to International Trade:

JBL provides all types of Non-Funded Credits in connection with Foreign/ International Trade. Foreign Trade related Funded Credits such as Issuing, Advising and Confirming of Documentary Credits like L/C on Sight \& Deferred Payment basis; Back to Back L/C; Acceptance against Usance Bills through Acceptance for Bill Payment (ABP); Lodgment/ Collection of Documentary Bills; Assist customers to insure all risks; Foreign Currency Dealings, etc. 
Fig 3.6: Different Foreign Trade Related Non-Funded Credits extended by JBL

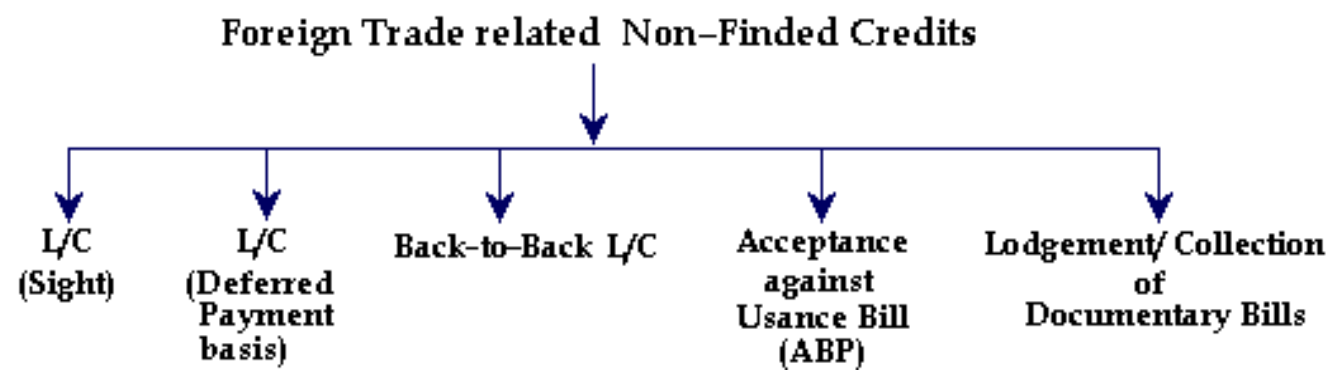

\section{Bank Guarantee:}

JBL issues Guarantees on behalf of its customer in the form of Bid-Bond; Performance Guarantee; Advance Payment Guarantee; etc.

Fig 3.7: Different types of Guarantee issued by JBL

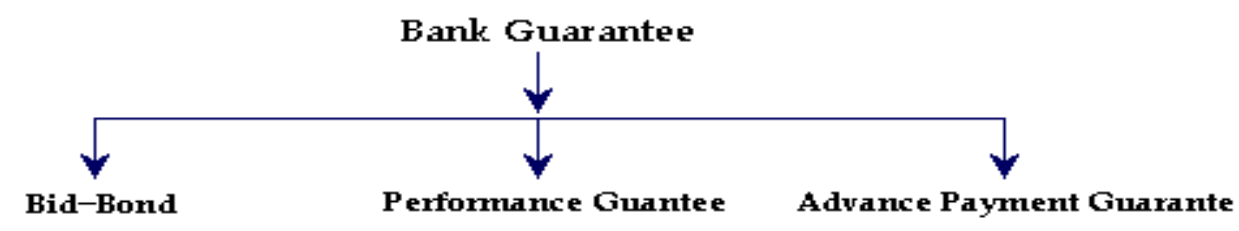




\section{CHAPTER 4}

\section{CREDIT RISK MANAGEMENT}

The word credit comes from the Latin "credo" means "I believe". It is a lender's trust in a person's/firm's/company's ability or potential ability to command goods or services of another in return for promise to pay such goods or services of another in return for promise to pay such goods or services at some specified time in the future. The making of loans and advances has always been prominent 
profitable function of the banks. Sanctioning credit to customers out of the funds at its disposal is one of the principal services of a modern Bank.

As a financial intermediary the primary objective of a bank is to collect deposits from the surplus units (who have surplus fund) and utilize the same by lending the deficit units (whose requires funds). Bank is the proper medium of those parties to utilize the capital properly. Bank guild the surplus parties where to invest. Bank collect deposits from surplus parties in return bank give them some percent of benefits that are gained out of the different loan or credit extended to the borrowers. Bank takes residual portion of benefit from the credits.

As Bank deals with the money collected from the depositors repayable on demand. So, it can not afford to lock up it fund for long or uncertain periods. Consequently, Bank must safeguards its deposits through effective management of all possible risks associated with its credits.

One of the most significant risks of a bank is exposed to is, what is generally termed as "Credit Risk", which is the primary risk in the banking system. Since the largest slice of income generated by a bank and a major percentage of assets is subject to this risk, it is obvious that prudent management of this risk is fundamental to the sustainability of a bank. Management of Credit Risks needs to be a robust process that enables the Banks to proactively manage the credit portfolio in order to minimize losses and earns an acceptable level of return for the Shareholders.

Risk is inherent in all aspects of commercial operation. However for Banks Credit risk is the fundamental to the sustainability of a bank. Thus Credit Risk is an essential factor that needs to be managed.

In simpler terms risk is the variability of return from its expected value. Risk is defined as the product of a hazard (such as damage costs) and the probability that this hazard occurs. In other words, (probability) $x$ (hazard) $=$ risk. The first two values must be known or at least estimated in order to define risk. Risk assessment is the process of analyzing potential losses from a given hazard using a combination of known information about the situation, knowledge about the underlying process, and judgment about the information that is not known or well understood.

The process of combining a risk assessment with decisions on how to address that risk is called risk management. Risk management is part of a larger decision process that considers the technical and social aspects of the risk situation. Risk assessments are performed primarily for the purpose of providing information and insight to those who make decisions about how that risk should be managed. Judgment and values enter into risk assessment in the context of what techniques one should use to objectively describe and evaluate risk. Judgment and values enter into risk management in the context of what is the most effective and socially acceptable solution.

The combined risk assessment and risk management process can be described as a six step process. The first three steps are associated with risk assessment and the last three with risk management 
Fig 4.1: Flow Chart of combined risk assessment and risk management process:

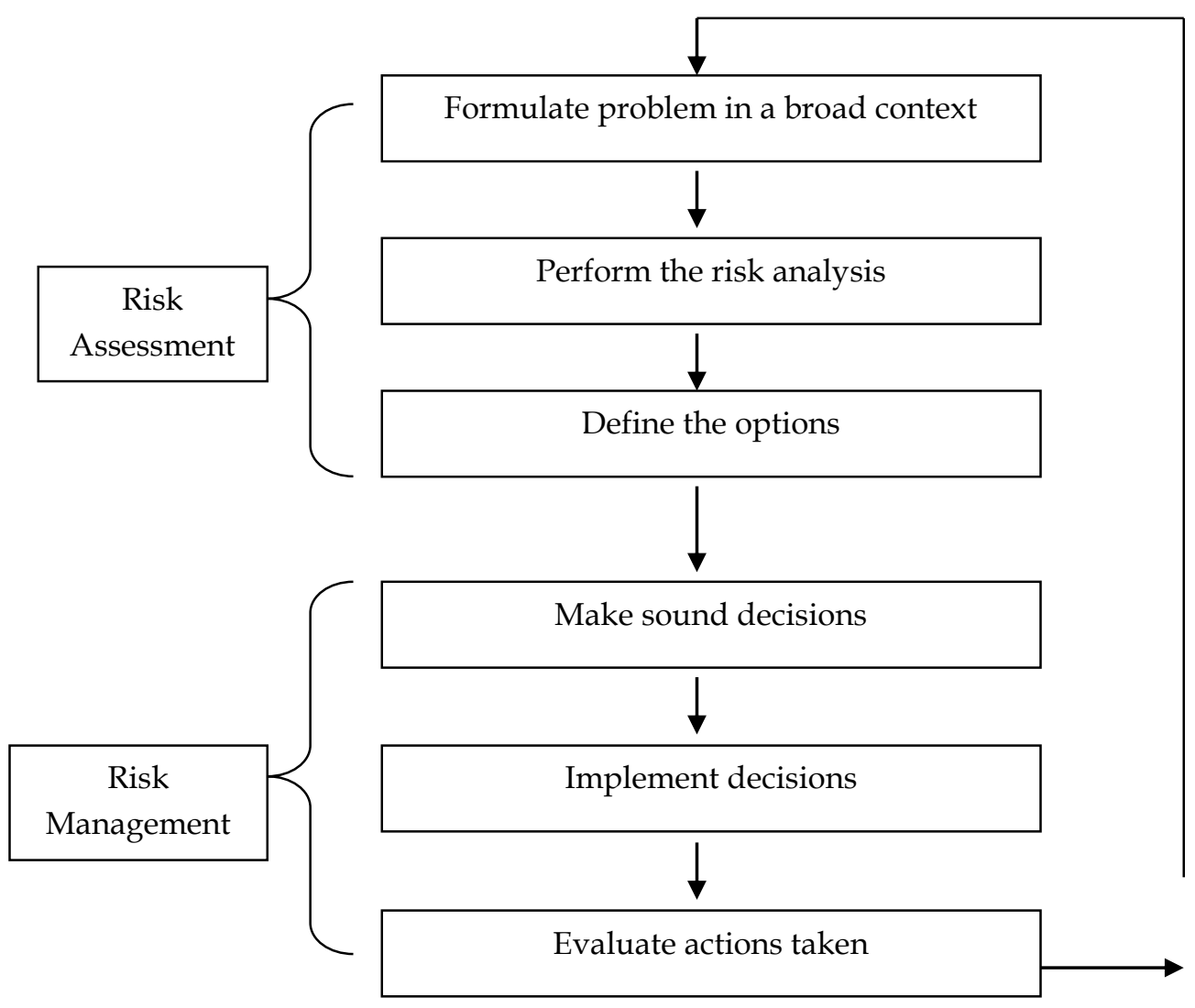

\subsection{CORE RISKS OF BANKING:}

The risks of banking are complex and multi-dimensional. Banks are exposed to a number of risks of different types. Resultantly, managing risk is an art of identifying, measuring and mitigating the risks.

In view of the above, Bangladesh Bank has identified 05(five) core risk area relating to banking business which are as follows:

Fig 4.2: Core Risks of Banking 


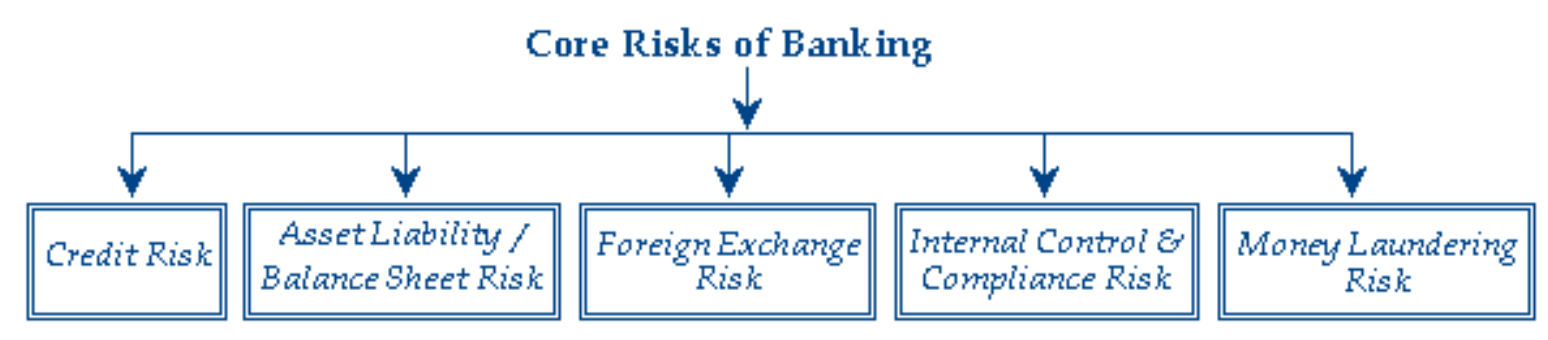

\subsection{THE MANAGEMENT OF CORE RISKS OF BANKING}

- $\quad$ Credit Risk Management - It has already been stated in this report that Management of Credit Risk is the most significant and key task of the bank. Credit Risk refers the probability of loss arising from the failure of a counterparty/ customer to perform as per agreement with the Bank. The failure may result from unwillingness of the borrower or decline in either his/ her financial condition or in the market scenario. Eventually, credit risk comes as the most sensitive part of risk management of the Bank.

Credit Risk has been discussed further in detail hereinafter.

- Asset Liability/Balance Sheet Risk Management - A Bank assets are mainly developed with and backed by its liabilities. Thus successful banking requires efficient and effective management of its assets and liabilities. Banks should have well-organized Asset Liability Management desk to monitor Balance Sheet Risk and Liquidity Risk.

The term Balance Sheet risk refers to potential change in earnings due to change in the rate of Profit, Quality of assets, etc.

On the other hand, Liquidity risk can be defined as the risk or chance of failure to meet up any withdrawal/ disbursement request by a counterparty/ customer.

- $\quad$ Foreign Exchange Risk Management - Since Foreign Exchange involves purchase and sale of foreign currencies against local currency, thus Foreign Exchange risk is the risk or chance of loss due to unexpected movement of market price of the currencies of different countries or the price of the assets denominated by foreign currencies.

In our country all the foreign exchange transactions are carried out on behalf of the customers against underlying exchange transaction rules and regulations laid down by Bangladesh Bank, UCPDC (Uniform Customs \& Practices for Documentary Credit) and other Government bodies. 
For effective and efficient management of Foreign Exchange Risk, Banks should have welldeveloped and well-structured Foreign Exchange Risk Manual and International Standard Dealing Room Manual.

- Internal Control \& Compliance - Internal Control \& Compliance is the key of good management and a strong core of an organization. It ensure safe and smooth operations within the organization. All the rules and regulation practiced in the banking industry are meant to safety and efficiency in banking operations of all kind.

Internal Control \& Compliance ensures that all the working units of a Bank abide by those rules and regulations without any fail. Sometimes operational loss arises out of errors and fraud due to lack of Internal Control \& Compliance.

- Prevention of Money Laundering Risk - Money laundering refers to the act of converting black/ illegal money into white/ legal money or property. The process of money laundering requires involvement of a bank, which is very alarming for the banking industry.

Money laundering risk can be defined as the loss of reputation and expenses incurred as penalty for being negligent in prevention of money laundering. For successful prevention and efficient management of the risk Banks should designate Compliance officers at Head Office and at the Branches, who independently review the transactions of the accounts to verify suspicious transactions.

\subsection{THE PROCEDURE OF MANAGING THE CORE RISKS IN JBL:}

Being a compliant bank JBL pursues the guidelines of Bangladesh Bank meticulously, in consequence of which the bank is being able to keep the risks at low ebb.

JBL has formulated a comprehensive Credit Risk Management Policy Document in line with the guidelines issued by Bangladesh Bank, which s discussed hereinafter.

The bank contemplates to have its assets assessed by an independent agency for the purpose of working out strategy to manage credit risks.

In order to manage the asset liability risk JBL has a well-organized Asset Liability Management Desk under direct supervision of a well-formed and well groomed Asset Liability Committee (ALCO) with a view to monitor and avert significant volatility in Net Profit Income (NPI), investment value of exchange earnings. The ALCO of the Bank monitors Balance Sheet risk and reviews liquidity contingency plan. In order to manage the contingent points of time and operation, the ALCO of the Bank calls for special meetings, analyzes the situation and decides what should be done to serve the Bank's interest most. 
The Head Office International Division of JBL plays the vital role to manage Foreign Exchange Risks in the process by checking the Foreign Exchange procedure performed by the Bank and by reporting it directly to the Managing Director of the Bank.

With a view to mitigate operational risk the bank has an effective Internal Control \& Compliance Division that endeavors to make the internal control system effectively by intensifying the internal audit, both comprehensive and special, of the Branches and Head Office. The Audit Committee of the Board of Directors reviews the audit reports and puts forth suggestions which are being followed with due care. The bank has the plan to have "Standard Operation Procedure" (SOP) formulated by a reputed consultant, which would strengthen the internal control system and mitigate the operation risks.

There is an anti money laundering policy in place approved by the Board of Director, which is in line with Guidance Notes on the subject issued by Bangladesh Bank. This contains all the control points to detect money laundering and to resist terrorist financing. The Board and the Management are fully committed to prevention of money laundering.

\subsection{CREDIT RISK}

Credit risk is the possibility that a borrower will fail to meet its obligation in accordance with agreed terms. Credit risk, therefore, arises from the Bank's dealings with or lending to corporate, individual and other Banks or financial institutions.

To prevent excessive flow of credit and proper use of it, banks require taking on the appropriate credit appraisal procedure to impose financial discipline on borrowers. The procedure that organize, control and motivate the borrowers will called credit management.

\subsection{NECESSITY OF CREDIT RISK MANAGEMENT:}

Banking in the new century is even more prosperous than the past owing to revolutionary advancement in technology, as well as, development of new ideas and systems. Consequently, every Bank has to be well-equipped to coup with the modern banking system and to adopt effective means and ways to negotiate its all possible risks especially the Credit Risk.

Credit constitutes the major part of the Bank's asset portfolio and managing credit risk is by far the most important concern of the Bank. The failure of a commercial Bank is usually associated with the problems in Credit portfolio and is less often the result of shrinkage in the value of other assets. As such, Credit portfolio not only features dominates in the assets structure of the Bank, it is critically important to the success of the Bank as well.

While Banks have faced difficulties over the years for a multitude of reasons, the major cause of serious banking problems continues to be directly related to lax credit standards for borrowers and counterparties, poor portfolio risk management, or a lack of attention to changes in economic or other circumstances that can lead to a deterioration in the credit 
standing of a bank's counterparties. This experience is common in both $\mathrm{G}-10$ and non $\mathrm{G}-10$ countries.

For most banks, loans and advances are the largest and most obvious source of credit risk; however, other sources of credit risk exist throughout the activities of a bank, including in the banking book and in the trading book, and both on and off the balance sheet. Banks are increasingly facing credit risk (or counterparty risk) in various financial instruments other than loans and advances, including acceptances, inter bank transactions, trade financing, foreign exchange transactions, financial futures, swaps, bonds, equities, options, and in the extension of commitments and guarantees, and the settlement of transactions.

Management of Credit Risks needs to be a robust process that enables Banks to proactively manage credit portfolio in order to minimize losses and earns an acceptable level of return. Given the fast changing dynamic global economy and the increasing pressure of globalization, liberalization, consolidation and disintermediation, it is essential that Banks have robust Credit risk management polices and procedures that are sensitive and responsive to these changes.

Since exposure to credit risk continues to be the leading source of problems in banks worldwide, banks should be able to draw useful lessons from past experiences. Banks should now have a keen awareness of the need to identify, measure, monitor, and control credit risk.

To provide a board guideline for the Management of Credit Risk towards achieving the objectives of the Bank, for efficient and profitable deployment of its mobilized resources and to administer the Credit portfolio in the most efficient way, a clearly defined, well planned, comprehensive and appropriate Credit policy and Control Guidelines of the Bank is a prerequisiteOn the other hand, JBL is a new generation Bank. It is committed to provide high quality financial services/products to contribute to the growth of G.D.P. of the country through stimulating trade \& commerce, accelerating the pace of industrialization, boosting up export, creating employment opportunity for the educated youth, poverty alleviation, raising standard of living of limited income group and over all sustainable socio-economic development of the country.

In achieving the aforesaid objectives of the Bank, Credit Operation of the Bank is of paramount importance. Hence, JBL has changed a lot as credit culture has been shifting towards a more professional and standardized Credit Risk Management approach.

In view of the above, the report is prepared on Management of Credit Risks through the case study of Jamuna Bank Ltd., which an effort to carry out a comprehensive study on how to manage the Credit risks and how to keep it in acceptable and appropriate level. 


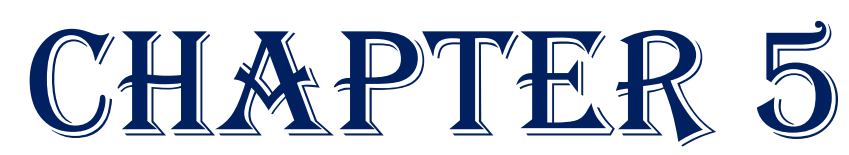

\section{BANGLADESH BANK'S GUIDELINES} FOR MANAGEMENT OF CREDIT

\section{RISKS}

Bangladesh Bank has provided directional guidelines to the banking sector with a view to improve the Credit Risk Management culture, establish minimum standards for segregation of duties and responsibilities and assist in the ongoing improvement of the banking sector in Bangladesh. These guidelines were prepared and endorsed by the senior credit executives from private sector, foreign and nationalized commercial banks operating in Bangladesh. Credit Risk Management is of utmost importance 
to Banks, and as such, policies and procedures should be endorsed and strictly enforced by the MD/CEO and the Board of the Bank.

The guidelines of Bangladesh Bank related with Management of Credit Risks have been organized into the following segments:

Fig 5.1: Guidelines of Bangladesh Bank on Management Credit Risks

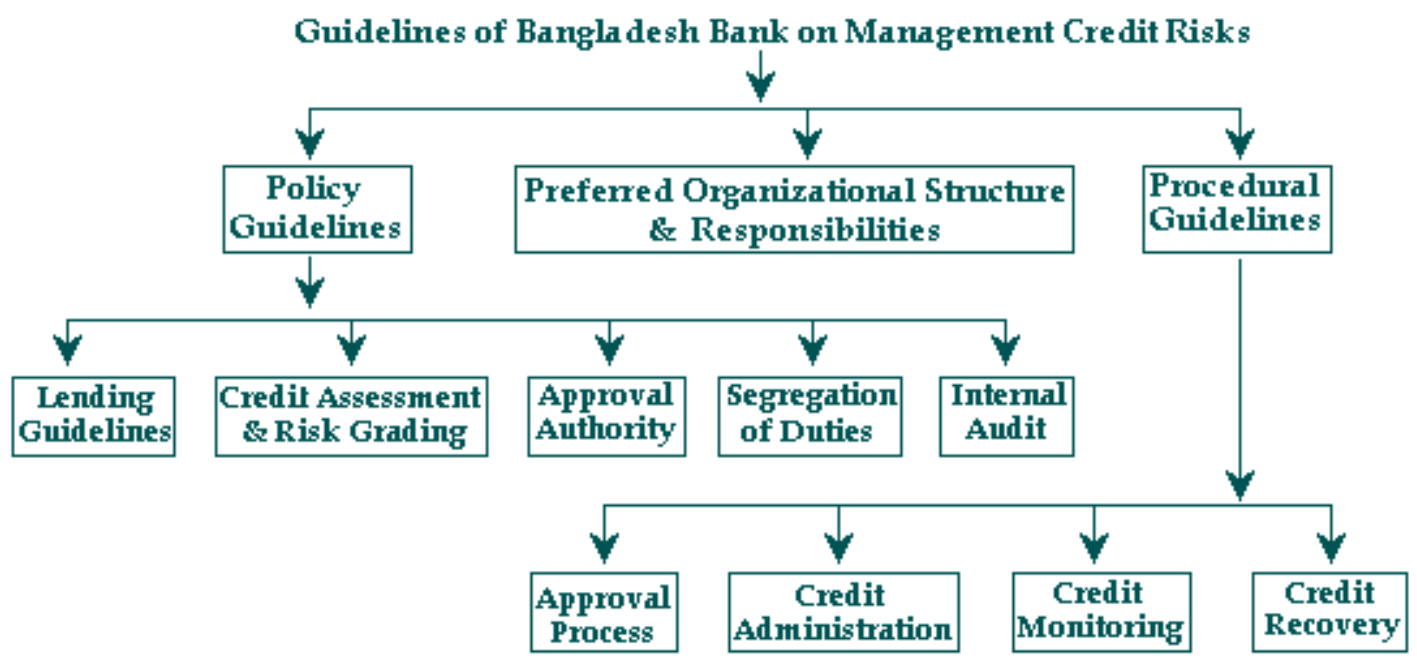

\subsection{POLICY GUIDELINES:}

Policy Guidelines focus on fundamental credit risk management policies that are recommended for adoption by all banks in Bangladesh. The guidelines outline general principles that are designed the implementation of more detailed lending procedures and risk grading systems within individual Banks.

\subsubsection{Different segments of Policy guidelines are discussed as follows :}

All banks should establish Credit Policies (Lending Guidelines) that clearly outline the management's view of business development priorities and the terms and conditions that should be adhered to in order for credits to be approved.

The lending guidelines should be updated at least annually to reflect changes in the economic outlook and the evaluation of the bank's credit portfolio. The lending guidelines should be approved by the MD/ CEO and the Board of Directors of the Bank based on the endorsement of the bank's Head of Credit Risk Management and the Head of Corporate. 
Any departure and deviation from the lending guidelines should be explicitly identified in credit applications and a justification for approval provided. Approval of credits that don't comply with lending guidelines should be restricted to the bank's Head of Credit or Managing Director/ CEO and the Board of Directors.

The lending guidelines should provide the key foundations for account officers/ relationship managers to formulate their recommendations for approval and should include the following ones :

- Industry and Business Segment Focus - The lending guidelines should clearly identify the business/ industry sectors that should constitute the majority of the bank's credit portfolio. For each sector, a clear indication of the bank's appetite for growth should be indicated for example Textiles : Grow; Cement : Maintain; Construction: Shrink.

D Types of Credit facilities - The type of credits that are permitted should be clearly indicated, such as Working Capital, Trade Finance, Term Loan, etc.

- Single Borrower/Group Limits - Details of the Bank's single Borrower/Group limits should be included as per Bangladesh Bank guidelines. Banks may wish to establish more conservative criteria in this regard.

- Lending Caps - Bank should establish a specific industry sector exposure cap to avoid over concentration in any one industry sector.

- Discouraged Business Types - Banks should outline industries or lending activities that are discouraged. As a minimum the following should be discouraged:

- Military Equipment/ Weapons finance.

- Highly leveraged Transactions.

- Finance of Speculative Investments.

- Logging, Mineral Extraction/ Mining, or other activity that is Ethically or Environmentally Sensitive.

- Lending to companies listed on CIB black list or known defaulters.

- Counterparties in countries subject to UN sanctions.

- Share Lending.

- Taking an Equity Stake in Borrowers.

- Lending to Holding Companies.

- Bridge Loans relying on equity/ debt issuance as a source of repayment.

- Credit Facility Parameters - Facility parameters e.g. maximum size, maximum tenor, covenant and security requirements, etc. should be clearly stated. As a minimum the following parameters should be adopted : 
- Banks should not grant facilities where the Bank's security position is inferior to that of any other financial institution.

- $\quad$ Assets pledged as security should be properly insured.

- Valuations of property taken as security should be performed prior to credits being granted. A recognized $3^{\text {rd }}$ part professional valuation firm should be appointed to conduct the valuations.

- Cross Border Risk - Risk associated with cross border lending. Borrowers of a particular country may be unable or unwilling to fulfill principle and/ or interest obligations. Distinguished from ordinary credit risk because the difficulty arises from a political event, such as suspension of external payments :

- Synonymous with political and sovereign risk.

- Third world debt crisis. For example, export documents negotiated for countries like Nigeria.

\section{Credit Assessment \& Risk Grading :}

- Credit Assessment - A thorough credit and risk assessment should be conducted prior to the granting of credits and at least annually thereafter for all facilities. The results of this assessment should be presented in a credit application that originates from the Account Officer/ Relationship Manager (RM), and is approved by Credit Risk Management (CRM). The RM should be the owner of the customer relationship, and must be held responsible to ensure the accuracy of the entire credit proposal submitted for approval. RM(s) must be familiar with the bank's Lending Guidelines and should conduct due diligence on new borrowers, principals and guarantors.

All Banks should have established KYC (Know Your Customer) and Money Laundering guidelines which should be adhered to at all times.

Credit Applications should summaries the results of the risk assessment and include, as a minimum, the following details :

- Amount and Type of Credit(s) proposed.

- Purpose of Credit(s) applied for.

- Credit Structure (Tenor, Covenants, Repayment Schedule, Interest)

- Security Arrangements.

In addition the following risk areas should be addressed :

- Borrower Analysis: The majority shareholders, management team, and group or affiliate companies should be assessed. Any issues regarding lack of management depth, complicated ownership structures or inter-group transactions should be addressed and risks mitigated. 
- Industry Analysis : The key risk factors of the borrower's industry should be assessed. Any issues regarding the borrower's position in the industry, overall industry concerns or competitive forces should be addressed and the strengths and weaknesses of the borrower relative to its competition should be identified.

- Supplier/ Buyer Analysis : Any customer or supplier concentration should be addressed, as these could have a significant impact on the future viability of the borrower.

- Historical Financial Analysis : An analysis of a minimum of 03(three) years historical financial statements of the borrower should be presented. Where reliance is placed on a corporate guarantor, guarantor financial statements should also be analyzed. The analysis should address the quality and sustainability of earnings, cash flow, leverage and profitability.

- Projected Financial Performance : Where term facilities are being proposed, a projection of the borrower's future financial performance should be provided, indicating an analysis of the sufficiency of cash flow to service debt repayments. Credit should not be granted if projected cash flow in insufficient to repay debts.

- Account Conduct : For existing borrowers, the historic performance in meeting repayment obligations (trade payments, cheques, interest and principal payments, etc.) should be assessed.

- Adherence to Lending Guidelines : Credit applications should clearly state whether or not the proposed application is in compliance with the bank's Lending Guidelines.

- Mitigating Factors : Mitigating factors for risks identified in the credit assessment should be identified. Possible risks include, but are not limited to: margin sustainability and /or volatility, high debt load (leverage/ gearing), overstocking or debtor issues; rapid growth, acquisition or expansion; new business line/ product expansion; management changes or succession issues; customer or supplier concentration; and lack of transparency or industry issues.

- Credit Structure : The amount(s) and tenor(s) of financing proposed should be justified based on the projected repayment ability and credit purpose. Excessive tenor or amount relative to business needs increases the risk of fund diversion and may adversely impact the borrower's repayment ability.

- Security : A current valuation of collateral should be obtained and the quality and priority of security being proposed should be assessed. Credit should not be sanctioned based solely on security. Adequacy and the extent of the insurance coverage should be assessed.

- Name Lending : Credit proposals should not be unduly influenced by an over reliance on the sponsoring principal's reputation, reported independent means, or their perceived willingness to inject funds into various business enterprises in case of need. Rather, credit proposals and the granting of credits should be based on sound fundamentals, supported by a thorough financial and risk analysis.

- Risk Grading - All banks should adopt a credit risk grading system. The system should define the risk profile of borrower's to ensure that account management, structure and pricing are commensurate with the risk involved. 
Risk grading is a key measurement of a Bank's asset quality and as such, it is essential that grading is a robust process. All facilities should be assigned a risk grade. Where deterioration in risk is noted, the Risk Grade assigned to a borrower and its facilities should be immediately changed. Borrower Risk Grades should be clearly stated on Credit proposal.

Approval Authority : The authority to sanction/ approve credits must be clearly delegated to senior credit executives by the Managing Director/ CEO and the Board based on the executive's knowledge and experiences. Approval authority should be delegated to individual executives and not to committees to ensure accountability in the approval process. The following guidelines should apply in the approval/ sanctioning of credits :

- Credit approval authority must be delegated in writing from the MD/CEO and Board (as appropriate), acknowledged by recipients and records of all delegation retained in CRM.

๑ Delegation approval authorities must be reviewed annually by MD/ CEO/ Board.

- The credit approval function should be separate from the marketing/ relationship management (RM) function.

- The role of Credit Committee may be restricted to only review of proposals i.e. recommendations or review of bank's credit portfolios.

- Approvals must be evidenced in writing, or by electronic signature. Approval records must be kept on file with the Credit applications.

- All credit risks must be authorized by executives within the authority limit delegated to them by the MD/ CEO/ Board. The "pooling" or combining of authority limits should not be permitted.

- Credit approval should be centralized within CRM function. Regional Credit Centers may be established.

? The aggregate exposure to any borrower or borrowing group must be used to determine the approval authority required.

- Any Credit proposal that does not comply with the Lending Guidelines, regardless of amount, should be referred to Head Office for approval.

๑ MD/ Head of Credit Risk Management must approve and monitor any cross-border exposure risk. 
- Any breaches of lending authority should be reported to MD/CEO, Head of Internal Control and Head of CRM.

- It is essential that executives charged with approving credits have relevant training and experience to carry out their responsibilities effectively. As a minimum, approving executives should have :

- At least 5(five) years experience working in corporate/ commercial banking as a relationship manager or account executive.

- Training and Experience in Financial Statement, Cash Flow and Risk Analysis.

- A thorough working knowledge of Accounting.

- A good understanding of the local industry/ market dynamics.

- Successfully completed and assessment test demonstrating adequate knowledge of the following areas :

- Introduction of accrual accounting.

- Industry/ Business Risk Analysis

- Borrowing causes.

- Financial Statement Analysis.

- The Asset Conversion/ Trade Cycle.

- Cash Flow Analysis.

- Projections.

- Credit Structure and Documentation.

- Credit Management.

- A monthly summary of all new facilities approved, renewed, enhanced and a list of proposals declined stating reasons thereof should be reported by CRM to the MD/ CEO.

- Segregation of Duties : Banks should aim to segregate the following lending functions ○ Credit Approval/ Risk Management.

$\rightarrow$ Relationship Management/ Marketing.

$\rightarrow$ Credit Administration.

The purpose of the segregation is to improve the knowledge and expertise in each department, to impose controls over the disbursement of authorized credit facilities and obtain an objective and independent judgment of credit proposals.

\subsubsection{Preferred Organizational Structure \& Responsibilities :}


The appropriate organizational structure must be in place to support the adoption of the policies. The key feature is the segregation of the Marketing/ Relationship Management/ Administration functions.

Credit approval should be centralized within the CRM function. Regional Credit Centers may be established, however, all applications must be approved by the Head of Credit and Risk Management or MD/ CEO/ Boards or delegated Head Office Credit executives.

- Preferred Organizational Structure : The following chart represents the preferred organizational structure :

\section{Fig 5.1: Preferred organizational structure}

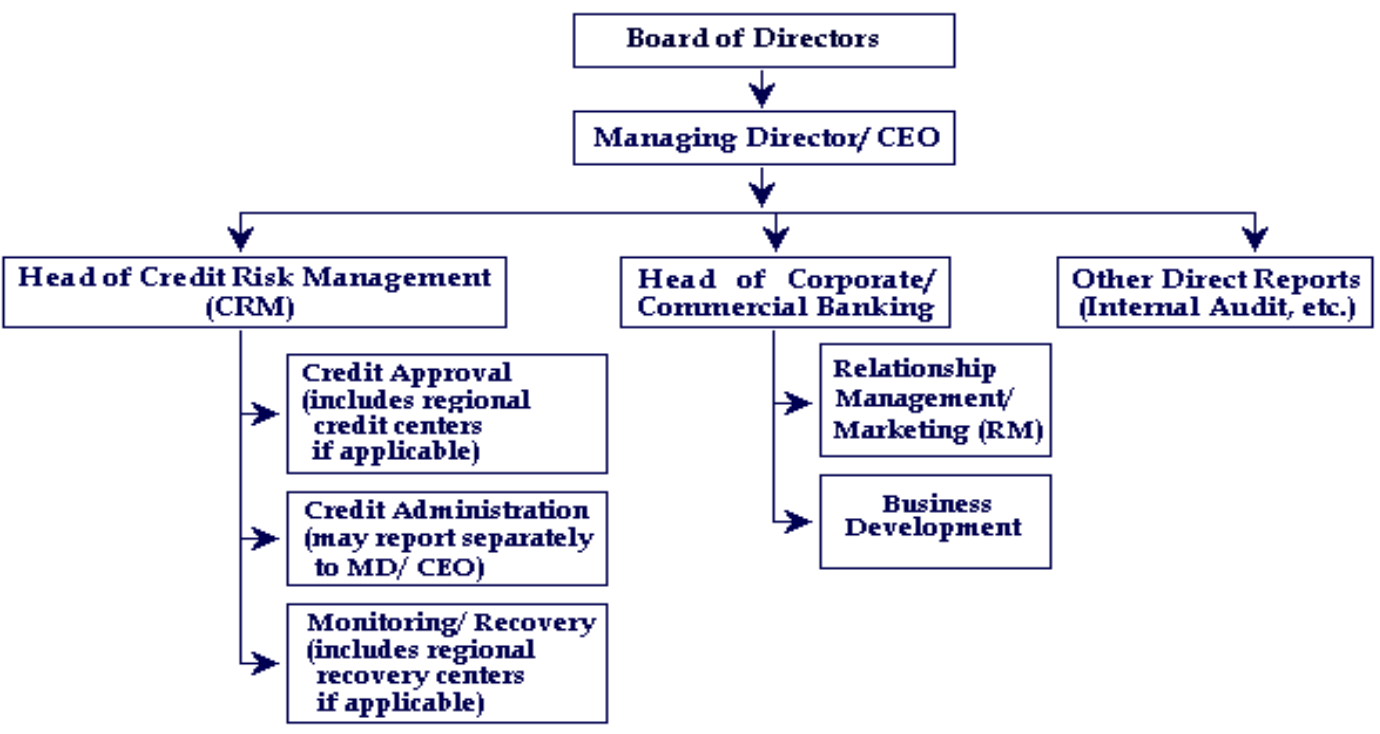

- Key Responsibilities : The key responsibilities of the above functions are as follows

\section{Credit Risk Management (CRM) :}

- Oversight of the bank's credit policies, procedures and controls relating to all credit risks arising from corporate/ commercial/ institutional banking, personal banking and treasury operations.

- Oversight of the bank's asset quality.

- Directly manage all Substandard (SS), Doubtful (DF) and Bad \& Loss (BL) accounts to maximize recovery and ensure that appropriate and timely Loan Loss Provisions (LLP) have been made.

- To approve (or decline) within the delegated authority, Credit Applications recommended by RM. Where aggregate borrower exposure is in excess of approval limits, to provide recommendation to MD/CEO for approval.

- To provide advice/assistance regarding all credit matters to line management/RM(s). 
- To ensure that lending executives have adequate experience and/or training in order to carry out job duties effectively.

\section{Credit Administration :}

- To ensure that all security documentation complies with the terms of approval and is enforceable.

- To monitor insurance coverage to ensure appropriate coverage is in place over assets pledged as collateral, and is properly assigned to the bank.

- To control credit disbursements only after all terms and conditions of approval have been met and all security documentation is in place.

- To maintain control over all security documentations.

- To monitor borrower's compliance with covenants and agreed terms and conditions and general monitoring of account conduct/ performance.

○ Relationship Management/Marketing (RM) :

- To act as the primary bank contact with the borrowers.

- To maintain thorough knowledge of borrower's business and industry through regular contact, factory/ warehouse inspections, etc. RMs should proactively monitor the financial performance and account conduct of borrowers.

- To be responsible for the timely and accurate submission of Credit Applications for new proposals and annual reviews, taking into account the credit assessment requirements.

- To highlight any deterioration in borrower's financial standing and amend the borrower's Risk Grade in a timely manner. Changes in Risk Grades should be advised to and approved by CRM.

- To seek assistance/ advice at the earliest from CRM regarding the structuring of facilities, potential deterioration in account or for any credit related issues.

\section{○ Internal Audit/Control :}

- Conducts independent inspections annually to ensure compliance with Lending Guidelines, operating procedures, bank policies and Bangladesh Bank directives. Reports directly to MD/ CEO or Audit Committee of the Board.

\subsubsection{Procedural Guidelines:}

Procedural Guidelines outline of the main procedures that are needed to ensure compliance with the policy guidelines.

- Approval Process : The approval process must reinforce the segregation of Relationship Management/ Marketing from approving authority. The responsibility for preparing the Credit Applications should rest with the RM within the corporate/ commercial banking department. Credit applications should be recommended for approval by the RM team and forwarded to approval team within CRM and approved by individual executives. 
The recommending or approving executives should take responsibility for and be held accountable for their recommendations or approval. Delegation of approval limits should be such that all proposals where the facilities are up to $15 \%$ of the bank's capital should be approved at CRM level, facilities up to $25 \%$ of capital should be approved by CEO/MD, with proposals in excess of $25 \%$ of capital to be approved by the Executive Committee/ Board only after recommendation of CRM, Corporate Banking and MD/ CEO.

Fig 5.2: The following diagram illustrates the preferred approval process :

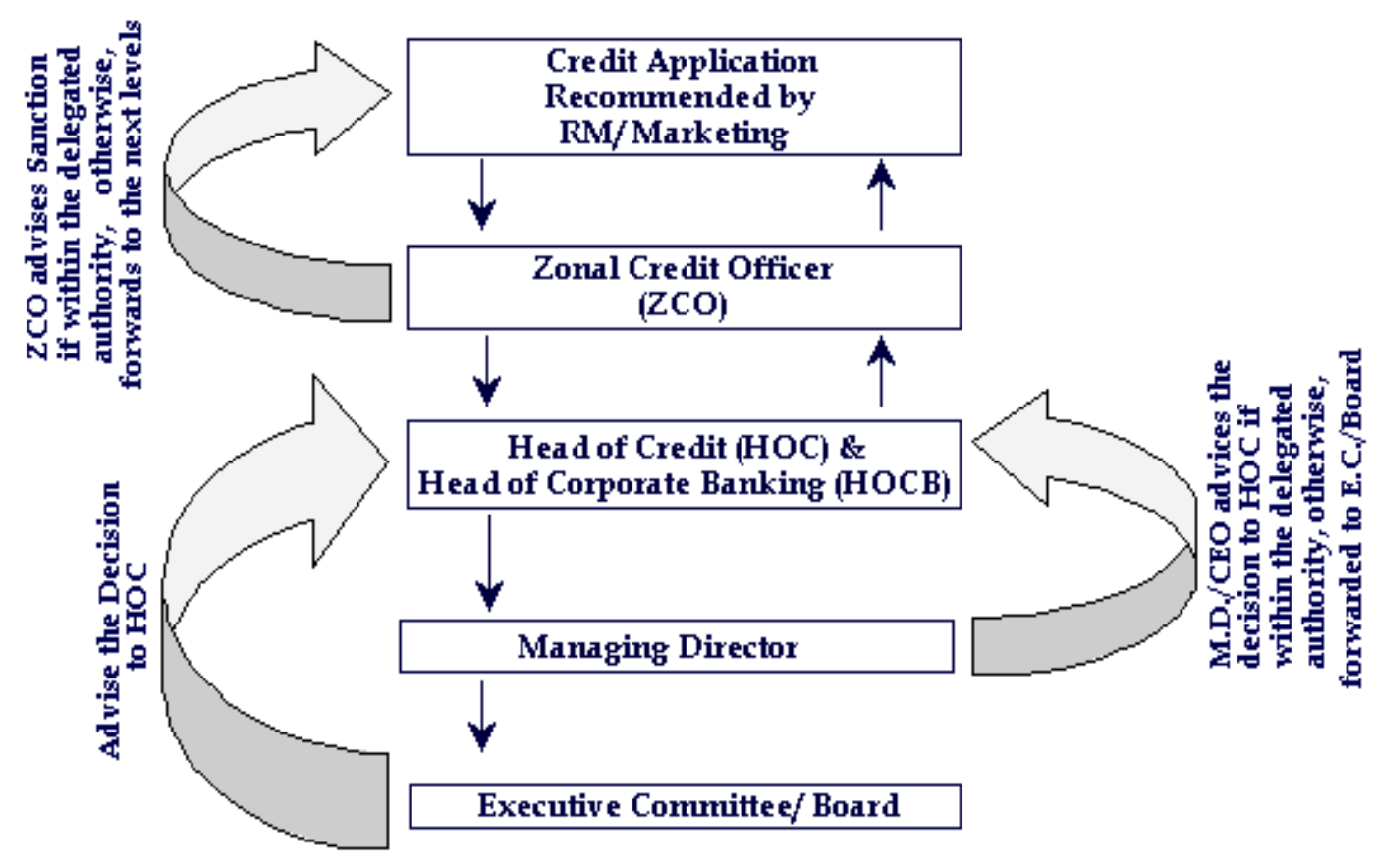

- Recommended Delegated Approval Authority Levels :

- $\mathrm{HOC} / \mathrm{CRM}$ Executives - up to $15 \%$ of Capital

- Managing Director/ CEO - up to $25 \%$ of Capital

- Executive Committee/ Board - all exceed 25\% of Capital

Appeal Process :

- Any declined credit proposal may be resubmitted to the next higher authority for re-assessment/ approval. However, there should no appeal process beyond the M.D./ CEO. 
- Credit Administration : The Credit Administration function is critical in ensuring that proper documentation and approvals are in place prior to the disbursement of credit facilities. For this reason, it is essential that the functions of Credit Administration be strictly segregated from Relationship/ Marketing in order to avoid the possibility of controls being compromised or issues not being highlighted at the appropriate level.

\section{Disbursement:}

- Security documents are prepared in accordance with the approval terms and are legally enforceable. Standard credit facility documentation that has been reviewed by legal counsel should be used in all cases. Exceptions should be referred to legal counsel for advice based on authorization from an appropriate executive in CRM.

- Disbursements under credit facilities are only be made when all security documentation is in place.

\section{$\rightarrow$ Custodial Duties:}

- Credit disbursements and the preparation and storage of security documents should be centralized in the regional credit centers.

- Appropriate insurance coverage is maintained and renewed on a timely basis on assets pledged as collateral.

- Security documentation is held under strict control, preferably in locked fireproof storage. 


\section{Compliance Requirements :}

- All required Bangladesh Bank returns are submitted in the correct format in a timely manner.

- Bangladesh Bank circulars/ regulations are maintained centrally, and advised to all relevant departments to ensure compliance.

- All third party service providers i.e. Surveyors, Lawyers, Insurers, CPAs, etc. are approved and performance reviewed on an annual basis. Banks are referred to Bangladesh Bank circular outlining approved external audit firms that are acceptable.

- Credit Monitoring : To minimize credit losses, monitoring procedures and systems should be in place that provide an early indication of the deteriorating financial health of a borrower. At a minimum, systems should be in place to report the following exceptions to relevant executives in CRM and RM team :

- Past due principal or interest payments, past due trade bills, account excesses and breach of credit covenants.

- Credit terms and conditions are mentioned, financial statements are received on a regular basis and any covenant breaches or exceptions are referred to CRM and the RM team for timely follow-up.

$\Rightarrow$ Timely corrective action is taken to address findings of any internal, external or regulator inspection/ audit.

- All borrower relationships/credit facilities are reviewed and approved through the submission of credit application at least annually.

Computer systems must be able to produce the above information for central/ Head Office as well as local review. Where automated systems are not available, a manual process should have the capability to produce accurate exception reports.

\section{$\rightarrow$ Early Alert Process :}

An Early Alert account is one that has risks or potential weaknesses of material nature requiring monitoring, supervision or close attention by management.

If these weaknesses are left uncorrected, they may result in deterioration of the repayment prospects for the asset or in the Bank's credit position at some future date with a likely prospect of being downgraded to CG 5 or worse (Impaired status), within the next twelve months..

Despite a prudent credit approval process, credits may still become troubled. Therefore, it is essential that early identification and prompt reporting of deteriorating credit signs be done to ensure swift action to protect the Bank's interest. The symptoms of early alert are by no means exhaustive and hence, if there are other concerns, such as a breach of credit covenants or adverse market rumors that warrant additional caution, an Early Alert report should be raised. 
Moreover, regular contact with customers will enhance the likelihood of developing strategies mutually acceptable to both the customer and the Bank. Representation from the Bank in such discussions should include the local legal adviser when appropriate.

- $\quad$ Credit Recovery : The Recovery Unit (RU) of CRM should directly manage accounts with sustained deterioration (a Risk Rating of Sub Standard i.e. 6 or worse). Banks may wish to transfer EXIT accounts graded $4-5$ to the RU for efficient exit based on recommendation of CRM and Corporate banking. Whenever an account is handed over from Relationship Management to Recovery Unit, a Handover/ Downgrade Checklist should be completed.

The RU's primary functions are :

๑ Determine Account Action Plan/ Recovery Strategy.

- Pursue all options to maximize recovery, including placing customers into receivership or liquidation as appropriate.

$\rightarrow$ Ensure adequate and timely loan loss provisions are made based on actual and expected losses.

- Regular review of grade 6 or worse accounts.

The management problem loans (NPL) must be a dynamic process and the associated strategy together with the adequacy of provisions must be regularly reviewed. A process should be established to share the lessons learned from the experience of credit losses in order to update the lending guidelines.

- NPL Account Management - All NPLs should be assigned to an Account Manager within the RU, who is responsible for coordinating and administering the action plan/ recovery of the account and should serve as the primary customer contact after the account is downgraded to substandard.

- Account Transfer Procedure - Within 07(seven) days of an account being downgraded to substandard (grade 6), a Request for Action (RFA) and handover/ downgrade checklist should completed by the RM and forwarded to RU for acknowledgement. The account should be assigned to an account manager within the RU, who should review all the documentation, meet the customer and prepare a Classified Loan Review Report (CLR) within 15(fifteen) days of the transfer.

Recovery units should ensure that the following s carried out when an account is classified as Sub Standard or worse :

- Facilities are withdrawn or repayment is demanded as appropriate. Any drawings or advances should be restricted and only approved after carefully scrutiny and approval from appropriate executives within CRM. 
- CIB reporting is updated according Bangladesh Bank guidelines and the borrower's Risk Grade is changed as appropriate.

- Loan Loss Provisions (LLP) are taken based on Force Sale Value (FSV).

- Credits are only re-scheduled in conjunction with the Large Loan Rescheduling guidelines of Bangladesh Bank. Any re-scheduling should be based on projected future cash flows and should be strictly monitored.

- Prompt Legal Action is taken if the borrower is uncooperative.

- Non Performing Loan (NPL) Monitoring - On a quarterly basis, a Classified Loan Review (CLR) should be prepared by the RU Account Manager to update the status of the Action/ Recovery Plan, review and assess the adequacy of provisions and modify the bank's strategy as appropriate.

- Non Provisioning and Write-off - The guidelines established by Bangladesh Bank for CIB reporting, provisioning and write-off of bad and doubtful debts and suspension of interest should be followed in all cases. These requirements are the minimum, and Banks are encouraged to adopt more stringent provisioning/ writeoff policies. Regardless of the length of time a credit past due, provisions should be raised against the actual and expected losses at the time they are estimated. The approval to take provisions, write-offs, or release of provisions/ upgrade of an account should be restricted to the Head of Credit or MD/ CEO based on recommendation from the Recovery Unit.

The following formula is to be applied in determining the required amount of provision :

\begin{tabular}{|c|c|}
\hline Particulars & Amount \\
\hline Gross Outstanding & $\mathbf{X X X}$ \\
\hline Less : (i) Cash Margin held or Fixed Deposits/ SP under lien & $(X X X)$ \\
\hline (ii) Interest kept in Suspense Account & $(X X X)$ \\
\hline $\begin{array}{l}\text { Credit Value } \\
\text { (for which provision is to be created before considering estimated } \\
\text { realizable value of Collateral Security held) }\end{array}$ & $X X X$ \\
\hline $\begin{array}{l}\text { Less: Eligible Security } \\
\text { (the value of Eligible security is determined as half of the } \\
\text { estimated Force Sale Value of the Collateral security held) }\end{array}$ & $(X X X)$ \\
\hline Net Credit Value & $\mathbf{X X X}$ \\
\hline
\end{tabular}




\section{CHAPTER 6}

CREDIT RISK MANAGEMENT AT JBL 


\subsection{CREDIT PRINCIPLES OF JAMUNA BANK LTD:}

Bangladesh bank has instructed all commercial banks to prepare a credit principle which will act as a guideline in credit risk management. Some salient features of credit principle of Jamuna Bank Limited are described below.

- The Bank shall provide suitable credit services and products for the market in which it operates. Product innovation shall be a continuous process.

- Loans and advances shall normally be financed from customers deposit and not out of temporary fund or borrowing from money market.

- $\quad$ Credit facilities shall be allowed in a manner so that credit expansion goes on ensuring quality i.e. no compromise with the Bank's standard of excellence. Credit is extended to customers who will complement such standards.

- $\quad$ All credit extension must comply with the requirements of Bank's Memorandum and Articles of Association, Bank companies Act as amended from time to time, Bangladesh Bank's instructions Circulars, Guidelines and other applicable laws, rules and regulations.

- The conduct of the credit portfolio should contribute, within defined risk limitation, to the achievement of profitable growth and superior return on the Bank's capital.

- Credit advancement shall focus on the development and enhancement of customer's relationship and shall be measured on the basis of the total yield for each relationship with a customer (on the global basis), though individual transactions should also be profitable.

- $\quad$ Credit facilities will be extended to those companies/persons, which can make best use of the facility thus helping maximize our profit as well as economic growth of the country. To ensure achievement of this objective lending decision shall be based mainly on the borrower's ability to repay.

- Diversification : The portfolio shall be well diversified sector wise, Industry wise, geographical area wise, maturity wise, size wise, mode wise, purpose wise. Concentration of credit shall be carefully avoided to minimize risk.

- $\quad$ Remunerative : If Credit facilities are granted on a transaction/one-off basis, the yield from the facility should be commensurate with the risk.

- $\quad$ Pricing : Pricing of Credits shall depend on the level of risk and type of securities offered. Rate of interest is the reflection of risk in the Transaction. The higher the risk, the higher is pricing. Interest rate may be revised from time to time in view of the change in the cost of Fund and market condition. Effective yield can be enhanced by requiring the customer to maintain deposit to support borrowing activities. Yield may be further improved by realizing Management fee, Commitment fee, service charge etc where possible.

- Proper staffing: Proper analysis of Credit proposal is complex and required high level of numerical as well as analytical ability and common sense. To ensure effective understanding of the concept and thus to make the overall credit port-folio of the Bank 
healthy, proper staffing shall be made through placement of qualified officials having appropriate background, who have got the right aptitude, formal training in Credit Risk Analysis, Bank's credit procedures as well as required experience

\section{Discouraged Business for Finance :}

In view of legal aspect, business risk and banking ethics following business are on discouraged list for Bank's finance:

จ Military Equipment/Weapons Finance.

? Highly Leveraged Transactions.

จ Finance of Speculative Investments.

- Logging, Mineral Extraction/Mining, or other activity that is Environmentally Sensitive.

- Lending to companies listed on CIB black list or known defaulters.

จ Counter-parties in countries subject to UN sanctions.

๑ Share Lending.

จ Taking an Equity Stake in Borrowers.

จ Lending to Holding Companies.

$\rightarrow$ Bridge Loans relying on equity/debt issuance as a source of repayment.

- Lending to a business enterprise where the loan cannot be repaid within a reasonable period except by borrowing elsewhere or by liquidating business.

- Loans to parties whose integrity is questionable.

- Loans secured by stock that has no ready market.

- Loans to business whose equity is substantially financed by Preference Shares.

จ Any other type which Bank may identify as discouraged from time to time.

\subsection{SEGREGATION OF DUTIES:}

Credit risk management guideline of Bangladesh Bank suggests that following credit related functions of the Bank be segregated and done by separate units:

- Credit marketing/Relationship (Corporate Division);

- Credit Approval/Credit Risk Management (CRM);

- Credit Administration (Documentation \& Disbursement \& Monitoring);

- Credit Recovery.

The purpose of the segregation are to improve the knowledge level and expertise in each department, to impose control over the disbursement of sanctioned loan facilities to avoid conflict of interest or compromise and to ensure quality of assets through transparent process.

\subsubsection{Segregated functions of different units:}




\section{Major Functions by Corporate Division}

- To solicit customers and maintain effective relationship with them.

- To collect sufficient credit information and process the same to conduct due diligence (Credit Analysis).

- To prepare well-dressed credit proposal and recommend the same to the Credit Risk Management department of the Credit Division.

\section{Duties and Responsibilities:}

Responsibilities of the division are, but not limited to, the following:

- To set short, medium and long term business goals and forward the same to the Credit Risk Management (CRM) unit of Credit Division for its ratification.

- To formulate plans and strategies to achieve specific business goals.

- To identify target customers, initiate/establish new customer relationships and renew/strengthen existing ones.

- To study market and competitive position and customize business plans \& strategies with changing environment on an on-going basis.

- To carry out credit analysis with due diligence, assess credit requirement of the customer, structure credit facilities, identify potential credit risks and mitigating factors thereto.

- To solicit customers and prepare credit information memorandum for specific syndication deal.

- To appraise and recommend proposals for participation in loan syndications arranged by other banks.

- To prepare well-dressed credit memo, addressing credit worthiness of borrower (with regard to character, capacity, cash, collateral, condition and control aspects).

- To structure loan terms/agreement to reasonably ensure borrower's capacity to repay loans as well as protection of interest of the bank and thereby interest of the depositors.

- To ensure compliance of bank's own policies and regulatory requirements.

- To coordinate with Credit Administration Unit for accomplishment of proper documentation and disbursement.

- To coordinate with Recovery Department of Credit Division to facilitate effective monitoring of loans.

- To collect latest credit information and revised risk grade of the borrower and place the same before the CRM Department for ratification.

- To minimize credit losses through risk assessment and timely identification of deteriorating credit risk of the customers.

- To develop new products and formulate means of mobilizing and allocating short, medium and long term resources.

- To ensure customer satisfaction in all respects. 
Jamuna Bank has a decentralized corporate banking structure. Creating a complete and centralized Corporate Division at Head Office will require preparation and time. Until establishment of a Corporate Division at Head Office, Head of Branches shall act as Relationship Manager for his respective Branch for doing the function of Corporate Division. Officers of Credit Department of the Branch shall work as team members of corporate functions. They shall do marketing of Bank's credit products, explore new business opportunities, negotiate terms and conditions, process credit proposals, maintain effective relationship with customers and submit proposals to CRM, Head Office for approval of business credit facilities beyond their delegated business power.

The Relationship Managers (RM) is the owner of the customer relationship and is responsible to ensure accuracy of the entire credit application submitted for approval.

It is essential that RMs know their customers and conduct due diligence on new borrowers, principals, guarantors to ensure such parties are in fact who they represent themselves to be.

\section{Credit Approval/Credit Risk Management (CRM)}

The Credit Risk Management Unit performs the following duties:

- Assess risks inherent in the credit proposal sent by Corporate Division and also evaluate proposed facility pricing based on risks, security, structuring and terms and conditions to suit the business condition and to protect Bank's interest.

- Compliance to the existing rules and regulations of the Bank and all regulatory authorities and laws of the country and to advise the Corporate Division for rectification, if required.

- Advise the Corporate Division about changes, if required, in the structure and terms and conditions of the proposed facility.

- Process credit proposal for approval of the competent authority.

- Issues sanction advice for credit facilities or decline.

- Maintain Limit Sanction Register.

- Review the performance of the customer on Off-site Basis and prescribe appropriate remedial measures, if required until the loan account becomes a "Special Mention" one.

- Review/revise risk grading of the customer from time to time based on the "Early Alert Report" and Downgrade Proposal submitted by Corporate Division.

- Handover credit to the Credit Monitoring \& Recovery Unit as and when it is degraded to Special Mention or below.

\section{Major Functions of CRM :}

- To update Bank's Credit Policy/Lending Guideline, procedures and control mechanisms related with all credit risks arising from corporate/commercial banking and retail banking etc.

จ To approve/decline credit proposal received from Corporate Division (presently from Branches) within delegated authority and to recommend to the higher authority if it is beyond delegation.

$\rightarrow$ To provide advice/assistance regarding all credit matters to Corporate Division/Branches. 
- Periodical review of different types of credits, maintain effective follow-up and supervision and take all possible measures in time to save from classification.

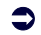

\section{Credit Administration Division (CAD)}

\section{Objectives:}

- To separate documentation and disbursement activity from credit approval process.

- To ensure discipline in Credit Management.

\section{Duties and Responsibilities:}

- Documentation: To ensure that security documents are prepared in accordance with approval terms and are legally enforceable.

- Disbursement: To allow disbursements of loan facilities only after completion of all documentation formalities. The branches shall send a copy of Certificate of Documentation (Check list) to Credit Administration Division (CAD), H.O. seeking authority for disbursement. In respect of credit facilities allowed by the Head of branch under the business power delegated to him, Certificate of documentation (check list) along with a copy of sanction advice to be sent to the CAD for disbursement authority. They shall send it by fax followed by mail. The CAD shall promptly respond for advising about disbursement preferably on the same day by fax followed by mail. If disbursement authority is given to the Branch with some exception i.e. incomplete documentation with the undertaking of the Head of Branch to get it completed within a given time frame having approval from the competent authority, the CAD shall continuously follow-up with the concerned Branch to ensure completion of the documentation within the given time frame. In the cases of Large Loan the representative of CAD may visit the Branch to verify the status of documentation.

- One officer of the branch shall be placed under administrative/ working control of CAD, H.O. for verifying documentation and control disbursement of credits.

- Custodial Duty : To ensure safekeeping of all security documents. Presently, the document files shall be preserved by the branches under joint custody. CAD, HO shall supervise, control and monitor the custodial matter. Following functions also fall in this category -

* Monitoring of Compliance to the conditions and covenants.

* Monitoring of past due, limit, expiry and documents deficiency.

* Internal, Bangladesh Bank Audit Compliance.

* Defaulters list circulation.

* Maintenance and circulation of Bangladesh Bank Circulars and ensure compliance.

- CIB Related Function: To collect CIB report of the borrower as and when asked by the Corporate Division/branches. They shall submit CIB statement to Bangladesh Bank and perform all CIB related activities.

- Compliance: To prepare and submit all required Bangladesh Bank returns in the correct format in a timely manner. To ensure that all Bangladesh Bank circulars/regulations are maintained centrally, and advised to all relevant departments to ensure compliance.

- Enlistment: To enlist and manage all third party service providers (Surveyors/Assessors, lawyers, insurers, CPAs etc.) and review their performance on an annual basis.

- Others: To prepare all monthly statements as required by the Management. 


\section{Credit Recovery \& Legal Division (CRLD)}

\section{Objectives:}

The core objective of establishing this unit is to separate monitoring and recovery activity from marketing, approval, documentation and disbursement.

\section{Major Functions :}

$\rightarrow$ Recovery of Non-performing and under performing loan from risk grade special mention account to below. With this end in view take all necessary measures inter-alia meeting with the customers, negotiate for restructuring, rescheduling, settlement by way of extension of time, waiver of partial interest, serving legal notice, foreclosure and sale of mortgaged / hypothecated / pledged property, filing suit in time, follow up suits, publishing sale notice in the News Paper, best effort to be made to keep classified loan within the minimum possible level.

๑To ensure that adequate provision against classified and unclassified loan is maintained as per Bangladesh Bank's guidelines.

จ All work related to loan classification in line with Bangladesh Bank's guidelines.

$\rightarrow$ Proper action and compliance to Artha Rin Adalat Ain.

๑They shall prepare periodic action plan.

จThe recovery department shall review documentation of non performing and under performing loans, meet the customers and prepare classified loan review report within 15 days of transfer and be approved by the Head of Credit.

- Classified loan review should be prepared by Recovery department on quarterly basis to update the status of the action/recovery plan and modify Bank's strategy.

$\rightarrow$ Where required proper legal action be taken in time.

๑Court cases are regularly followed -up and necessary steps are taken for early resolution.

$\rightarrow$ Recovery department shall determine the Forced Sale Value (FSV) for accounts grade 6 and worse.

\section{Internal Control \& Compliance Division (ICCD)}

Internal Audit shall conduct independent inspection annually to ensure compliance with credit guidelines, operating procedures and Bangladesh Bank's guidelines. Internal audit department shall report directly to the Managing director.

\section{Role of Head Office Credit Committee}

- Review of Credit proposals and recommend to the Managing Director.

- Review of Bank's loan portfolio. 
- The Head of Branch is the Relationship Manager for corporate function of his branch. He shall also exercise his business power with due diligence and prudence.

- KYC shall be done on the customer. In this respect he shall arrange for physical visit to the business of the lending customer by any responsible bank officer, know about the nature of business, volume, discuss with the important personality of the locality, his business colleagues and neighbors and try to know about the genuineness, honesty and integrity of the customer and his business dealings and to be documented in visit report. He shall take all precautionary measures in respect of Money Laundering issue.

- Comply with applicable laws, regulations of Bangladesh Bank, Credit Policies and Circulars of the Bank.

- Latest CIB report on the customer has to be obtained and found favorable.

- Ensure continuous review of credit facilities, Early Alert Account be identified and reported to CRM through Corporate Division, Head Office.

- Ensure that all covenants are being complied with by the customers.

\subsubsection{Delegation of Business Powers:}

\section{Norms for Exercising Delegation of Business Power :}

a The Board of Directors is the source of all powers. It can delegate power to any committee, The Managing Director and different tiers of the Management from time to time for smooth operation of the Bank.

$\Rightarrow \quad$ The Managing Director can exercise all the powers vested in other officers of the Bank. The Managing Director can suspend delegated power of any Executive /officer through specific or general order for reasons to be recorded in writing.

- The delegated power should be exercised judicious and conforming to the credit policy of JBL, relevant regulations and laws.

- The Board shall approve grade wise general delegation of Power to the different tiers of the Management. But one executive/ officer can exercise delegation of power up to the extent specifically vested to the concerned executive /officer by the Managing Director through letter by name. The Managing Director shall delegate power considering knowledge, experience, judicious judgment ability, reliabilities and trustworthiness of the executive /officer. The proper use of the power by the individual executive/officer shall be reviewed annually and the power be re-casted.

- If an executive/officer is temporarily posted in a position to substitute an executive of higher grade, he can exercise delegated power relevant to his own grade, not higher grade.

- Credit limits sanctioned by Board/EC can be renewed by the Managing Director on the same terms and conditions without any change/ amendment of any condition subject to satisfactory transactions/ performance. 
- The Management cannot allow any credit facility to the customer / group to whom credit limit has been approved by the Board/EC. The Management cannot change/alter/amend any terms and conditions of the credit facilities sanctioned by the Board/EC.

( Before opening the L/Cs mode of retirement of documents be settled to avoid any forced post import loan.

- Following tiers of management can exercise delegation of business power subject to the extent of specific delegation by the Managing Director:

- At Head Office the Managing Director and in his absence by the Deputy Managing Director.

- Branch Managers.

$\rightarrow \quad$ One customer/group should not be accommodated credit facilities from more than one branch without approval of Head office.

- The sanctioning officer/ executive cannot sanction any credit facility in his name or his relatives without approval of Head office. BCD Circular No. 5 dated 10.04.1979, and subsequent circulars of the Bangladesh Bank shall be followed to define relatives. Relatives means :

- Husband/ Wife.

- Father.

- Mother (including step-mother).

- Son (including step- son).

- Son's wife.

- Daughter (including step-daughter).

- Father's father.

- Father's mother.

- Mother's mother.

- Mother's father.

- Wife's father.

- Wife's mother (including step-mother).

- Wife's brother (including step- brother).

- Wife's sister (including step- sister).

- Son's son.

- Son's daughter.

- Brother (including step- brother).

- Brother's wife.

- Sister (including step- sister). 
- Sister's husband and his father and mother.

- Sister's husband's brother and sister.

- Uncles (own paternal and maternal).

- Aunts (own paternal and maternal).

- First cousins (from both father's and mother's side)

The first and foremost criteria of allowing credit are the proper and correct selection of borrowers.

The borrower should be selected on the following basis :

- Must be a man of integrity and must enjoy good reputation in the market.

- Must have the capacity and capability for utilizing credit properly and profitably.

- The enterprise of the borrower must be viable and profitable. That is to say, the proposal of the borrower must be evaluated properly and carefully so as to ascertain its viability and profitability. The enterprise must be able to generate sufficient fund for debt servicing.

- A customer to whom credit to be allowed should be as far as possible within the command area i.e. area of operation of the branch. For example, Moulvi Bazar Branch, Dhaka should not normally accommodate a party of Motijheel area. Deviations, if any, are not to be explicitly explained in the proposal.

- A customer should not be accommodated with different types of credit / investment facilities, nor should the same customer be allowed credit facilities, in different names without the authority of Head Office.

- No discretionary power will be applied by the branches to accommodate customers to whom Head Office has already sanctioned limits.

- The powers will be exercised by the authorized Executives/ Officers only when such Executives/ Officers are specifically allowed by the Managing Director in writing addressed to him.

- The credit disbursing officer will also remain responsible for completing the documentation formalities before disbursing the credits.

- Powers will be exercised in all cases subject to credit restrictions imposed by Bangladesh Bank from tome to time.

The Executive of different level can exercise their delegation of power mode wise up to the limit. They can sanction credit facilities under different mode both funded and non-funded as per delegation. But their total sanctioning limit per customer/ group under different modes shall not exceed the following cap :

Table 6.1: Cap of Delegated Powers: 


\begin{tabular}{|ccc|}
\hline Designation & & (Funded \& Non-Funded) \\
\hline M.D. & Tk.100.00 Lac & Tk.300.00 Lac \\
\hline A.M.D./ D.M.D. & Tk.50.00 Lac & Tk.200.00 Lac \\
\hline S.E.V.P. & Tk.25.00 Lac & Tk.150.00 Lac \\
\hline E.V.P. & Tk.20.00 Lac & Tk.100.00 Lac \\
\hline S.V.P. & Tk.15.00 Lac & Tk.75.00 Lac \\
\hline V.P. & Tk.10.00 Lac & Tk.60.00 Lac \\
\hline S.A.V.P. & Tk.7.00 Lac & Tk.50.00 Lac \\
\hline A.V.P. & Tk.5.00 Lac & Tk.40.00 Lac \\
\hline \hline
\end{tabular}

The lending caps do not include loan against financial obligation, documentary bills purchased and issuance of Bank Guarantee against counter guarantee of First Class Foreign Bank. However, the amount excluding above cap is placed before Executive Committee and Board of Directors for approval.

\subsection{CREDIT RISK ASSESSMENT:}

A thorough credit risk assessment is conducted prior to the sanctioning of credit facilities. Thereafter it is done annually for each relationship. The result of this assessment is presented in the credit proposal originated from the Relationship Manager (presently Head of the Branch).

The Relationship Manager (presently Head of Branch) is the owner of the customer relationship and it's his responsibility to ensure the accuracy of the entire credit proposal submitted for approval. Relationship Manager must be familiar with the Bank's Lending Guidelines and should conduct due diligence on the borrower, principals and guarantors. They must conduct necessary KYC (Know Your Customer) part on the customer and Money Laundering Guidelines be adhered to.

Following risk areas in the credit proposal is addressed and assessed before sending to Head Office:

Borrower Analysis:

- Shareholding. 
- Reputation.

- Education.

- Experience - success history.

- Net worth.

- Age etc.

Industry Analysis:

- Industry Position/Threat/Prospect.

- Risk factors pertaining to the industry.

- Borrower's position / share in the industry.

- Strength, weakness of the borrower compared to the competitors etc.

Supplier/ Buyer Risk Analysis :

Concentration on single/few buyer/supplier is addressed.

Demand Supply position.

Technical feasibilities / Infrastructural facilities.

Management Team's Competence.

Seasonality of demand.

Debt-Equity Ratio

Historical Financial Analysis :

- An analysis of 3 years historical financial statements.

- Earning - its sustainability.

- Cash flow.

- Leverage.

- Profitability.

- Strength and reliability of Balance Sheet etc.

Projected Financials:

- Sufficiency of cash flows to service debt repayment.

- Debt Service Coverage Ratio. 
Trade Checking.

- Account conduct: For existing customer - the repayment history, credit turnover, study of account statement.

- If the customer is proposed to be migrated from other Bank, statement of account from present Banker is required.

- Allied deposit with Jamuna Bank.

- Other business with Jamuna Bank.

After credit risk assessment is completed and the party is found to be creditworthy then following issues are considered -

(i) Pricing:

- Effective Rate of Return.

- Return on Investment.

(ii) Credit Structuring: Amount, Tenor, relation consistency among different modes (L/C \& LTR/LIM) are realistic. Excessive amount and tenor compared to genuine business need increases the risk of fund diversion and may adversely impact the borrower repayment ability. Low dose of Credit facility compared to genuine requirement leads to low profitability and loosing valued clients.

(iii) Security: A current valuation of collateral security by Professional Enlisted Surveyor be obtained with photograph and site map. Collaterals within command area of the respective branch location are preferred. Third Party property and vacant land should be discouraged. Credits are not considered based solely on collateral. Adequacy and extent of Insurance coverage should be assessed. Insurance Policy should be obtained from approved Insurance Company. Premium should be paid through Bank, duly stamped money receipt be obtained. Insurance Policy is held by the Bank. The Policy is renewed in time. Letter of authority be obtained from the customer to debit account to pay premium for renewal/enhancement of the policy.

(iv) Succession issue: Margin, volatility of business, high debt (Leverage / gearing), over stocking, huge receivables with long aging, rapid expansion, new business line, management change, lack of transparency should be addressed. 
(v) Adherence to credit guidelines: It should be clarified whether the customer is agreeable to comply with guidelines in respect of regulatory requirement and Bank's policy requirement. Any deviation be clearly identified and maintained.

(vi) Mitigating Factors: Risk factors are identified and side by side mitigating factors of those risks should also be mentioned to justify the proposed facility.

(vii) Environmental factors.

(viii) Employment generation and contribution to the national economy.

\subsection{DETERMINING CREDIT FACILITIES PARAMETER:}

When the applicant is found to be creditworthy, following credit facility parameters get attention.

Maximum Size :

- Directives of Bangladesh Bank is meticulously followed when it comes to maximum size of credit facility that can be provided to a single customer; however it is revised from time to time. Presently Bangladesh Bank BRPD Circular No. 05 dated 09.04.2005 decided that total outstanding financing facilities to any single person or enterprise or organization of a group shall not at any point of time exceed 35\% of Bank's total capital subject to the condition that the maximum outstanding against fund based financing facilities (Funded facilities) do not exceed $15 \%$ of the total capital.

Non-funded credit facilities e.g. letter of credit, guarantee etc. can be provided to a single large borrower. But under no circumstances the total amount of the funded and non-funded credit facilities shall exceed $35 \%$ of Bank's total capital.

However, in case of export sector single borrower exposure limit shall be $50 \%$ of the Bank's total capital. But funded facility in case of export credit also shall not exceed $15 \%$ of total Capital Fund of the Bank.

- Credit sanctioned to any individual enterprise or any organization of a group amounting to $10 \%$ or more of Bank's total capital shall be considered as Large Loan.

- Credit limit in each case shall be fixed after assessment of actual business need maintaining required Debt Equity Ratio, considering Debt Service Coverage Ratio, Pay Back Period, and Security Coverage etc.

Maximum Tenor:

\section{Short-term Loan :}

- Maximum period 12(twelve) months. Actual loan period shall be fixed on a case to case basis considering cycle of business and requirement. 


\footnotetext{
$\checkmark \quad$ Medium-term Loan: considering repayment capacity and projected cash flow.

\section{Long-term Loan :}

- Loan period shall be for more then 36 months.
}

- Loan period shall be for more than 12 months and up to 36 months

Actual loan period shall be fixed considering repayment capacity and projected cash flow. Securities:

All attempts should be made to cover loans by tangible securities as far as possible. Security shall be stipulated on a case to case basis.

As per BRPD Circular No. 05 dated 27.04.2005 following securities have been identified as eligible security for determining base for provisioning for classified loans :

- Lien on Bank Deposit - 100\%.

- Market value of Gold / Gold Ornaments pledged to the Bank-100\%.

- Lien on Government Bond/ Savings Certificates - $100 \%$.

- Guarantee given by Government of Bangladesh-100\%.

- Market value of Easily Marketable Security/Saleable Goods pledged to the Bank $-50 \%$.

- Market value of Registered Mortgaged Land and Building along with Registered Power of Attorney favoring the Bank to sell the property.

- $50 \%$ of Face Value or $50 \%$ of Average Market Value of last 06 (six) months of Shares / Securities traded in the stock exchanges.

Besides following securities are also obtained on a case to case basis :

- Hypothecation of Stock and Machinery.

- First charge/ charge on the Fixed and Floating Assets of Limited Company with the Registrar of Joint Stock Companies \& Firms.

- Corporate Guarantee of another Company backed by Board Resolution.

$\rightarrow \quad$ Personal Guarantee under cover of forwarding letter.

D Bank Guarantee.

- Assignment of Bill/ Receivables duly accepted by the employer to issue cheques in favor of the Bank.

O Ownership of Vehicles / Assets in the name of the Bank.

$\rightarrow \quad$ Assignment of Surrender value of Life Insurance Policy. 
- Pari-Passu Security Sharing Agreement.

$\rightarrow \quad$ Post Dated Cheque under cover of Forwarding Letter.

$\rightarrow \quad$ Trust Receipt.

Covenants:

- Ownership statement of the borrowing company shall not be changed without approval of the Bank.

- Current Ratio as mentioned in the credit application /sanction term shall be maintained.

$\rightarrow \quad$ The customer shall not borrow from any other source without approval of the Bank.

- The customer shall not go for expansion without consent of the Bank.

- The customer shall not withdraw profit/declare dividend without consent of the Bank.

a The customer shall submit financial statements within 30 days from the year/half yearend.

\subsection{VALUATION OF SECURITIES:}

Valuation of securities is a very important task. Any negligence or mistake in this task can increase bank's exposure significantly. Jamuna Bank Limited takes following steps while valuating securities -

(i) Valuation of Goods :

- Loan against Imported Merchandise (LIM): LIM facility is allowed as post-import finance against imported goods under our L/Cs. LIM facility should not exceed invoice value net of L/C margin unless the Bank agrees to finance duties/VAT. However, where market price of the goods is lower than landed cost necessary arrangement should be made with the customer to obtain additional deposit. The price at which LIM goods to be released to customer should be approved by Head Office or it may be at market price or landed cost whichever is higher.

$\rightarrow$ Cash Credit (Pledge): Valuation of the goods to be pledged to the Bank against Cash Credit (Pledge) limit shall in no cases exceed:

- $\quad$ The landed cost or market prices whichever is lower in case of imported goods.

- $\quad$ The ex-mill/factory price or market price whichever is lower in case of domestically manufactured commodities as evidenced by invoice. 
- $\quad$ The wholesale price/competitive market price duly verified by the Branch and approved by Head Office.

(ii) Valuation of Collateral Security :

In case of taking mortgage of Land and Building as collateral security to secure Bank's Advances the following instructions should be meticulously followed by the Branches:

- In all cases where the value of collateral security is Tk25 Lac and above the valuation of the property must be done by enlisted surveyor or the Bank. The property should be physically inspected and jointly verified by Bank's Officers, one of whom should be the Branch Manager or the 2 nd Officer. A valuation certificate mentioning market value and forced sale value should be prepared in the designated form supplied to the Branches and to be jointly signed by the above mentioned 02(two) inspecting officers of the Bank. The forced sale value of the collateral security will have to be 1.5 times higher than the facility/facilities allowed unless specifically waived by the approving authority giving full justification.

- "A Site Plan" and "Map" along with 3R size distinct photographs of the mortgaged property covering full exposure from 3 angles mentioning detailed particulars on the back of the photographs duly authenticated by the authorized officer(s) is obtained by the Branches.

- It is ensured that the collateral security is in the physical possession of the mortgagor(s) and the mortgagor(s)/owner(s) has/have valid title over it.

- A certificate from the Bank's Lawyer to be obtained that the mortgage formality has been properly created.

- Vacant land and Third Party Property is discouraged as mortgage.

- Kutcha and temporary structure on the land be excluded from valuation.

- In case of Third Party Property, photograph of the Mortgagor be obtained duly attested by the borrower and an affidavit before 1st class Magistrate be obtained.

- Registered Mortgaged along with Registered Power of Attorney in favor of the Bank to sell the property without intervention of the court is obtained.

\subsection{DISTRIBUTION PROCESS \& DOCUMENTATION:}


- Authority of approval and disbursement is separate. Credit Risk Management Unit approves credit facilities while Credit Administration Unit assumes Disbursement Authority.

- CRM issues Loan Sanction Advice to the Branch enclosing therewith a checklist of documentation to be completed before disbursement to secure the credit facility.

- The Branch completes documentation as per checklist and submits a checklist duly filled in to the Credit Administration Unit, Head Office, duly signed by the Head of the Branch (RM) and countersigned by the officer of the Credit Administration posted at the Branch seeking Disbursement Authority. The Credit Administration Officer shall countersign the checklist after verifying the proper execution of documents/security/collaterals. The Credit Administration Officer posted at the Branch shall be under administrative and working control of Credit Administration Unit, Head office.

- After getting the Documentation Checklist from the Branch, the Credit Administration Unit compares the documents obtained with the sanction letter and prepares office note for approval to issue Disbursement Authority mentioning the exception with reason and definite time schedule for obtaining the same as committed by the Head of Branch.

จ After getting Disbursement Authority the Branches disburse the facility.

$\rightarrow \quad$ For the Credit facilities sanctioned by the Head of the Branch under his delegation the following procedures shall be followed for disbursement.

- Loan against financial obligation, Inland Documentary Bills Purchased, L/C, Bank Guarantee shall be disbursed after signing the documentation Checklist by the Head of the Branch and countersigned by the Credit Administration Officer posted at the Branch duly verified the documents.

- $\quad$ Other funded credit facilities shall be disbursed after getting Disbursement Authority from Credit Administration Unit, Head Office observing usual formalities.

- Lawyer's Satisfaction Certificate to be obtained regarding documentation where there are securities/collaterals other than Personal Guarantee and Financial Obligation.

- For incomplete documentation temporary waiver to be obtained from the CRM, Head Office.

$\rightarrow \quad$ Excess Over Limit, if any, shall not be disbursed without Pre-fact approval of Head Office.

- Corporate Division and Branches shall maintain credit files of the customers. Credit Division shall maintain customer-wise approval file. 
- Search shall be conducted periodically about collaterals both with RJSC and SubRegistrar Office about encumbrance of the properties.

- Bank's Legal Counsel shall certify the legal documentation, borrower's legal standing and enforcement of Bank's interest.

- Mortgage documents shall be properly vetted by Bank's Legal Counsel.

- Registered Mortgage of property shall be supported by Registered Irrevocable Power of Attorney favoring the Bank to sell the property.

\subsection{CREDIT MONITORING:}

- Computer generated list of Exceptional Advance are being obtained from the Branches on daily basis which are examined at CRM and any major exception be brought to the knowledge of Senior Management.

- Credit Administration Unit, Head Office brings the list of documentation shortfall/deficiencies to the knowledge of Senior Management at regular basis and corrective measures shall be taken.

- Credit turnover in cash credit and overdraft accounts, past dues, collateral shortfall, covenant Branch shall be reviewed on a regular basis.

จ Recurring transactions are not allowed for one time transaction/limit.

- Credit limit expiry dates diary are maintained and followed-up.

$\curvearrowright \quad$ Use of Credit money are monitored through analysis of financial statements.

$\Rightarrow \quad$ Financial statements of the customers being obtained on a regular basis and changes in the financial condition are monitored.

- Borrowers are communicated ahead of time as and when installments are due.

- Non-payment and late payment of installment are communicated to the Senior Management.

- CIB Report from Bangladesh Bank is obtained and reviewed on a periodic basis.

- Progress against work order/contract financed by the Bank is periodically reviewed.

$\rightarrow \quad$ Timely renewal of limit shall be ensured informing Branches two months ahead of expiry dates.

\subsection{CREDIT RISK GRADING (CRG):}


Identifying and assessing credit risk is essentially a first step in managing it effectively. Credit risk grading is an important tool for credit risk management as it helps the Banks and financial institutions to understand various dimensions of risk involved in different credit transactions. The aggregation of such grading across the borrowers, activities and the lines of business can provide better assessment of the quality of credit portfolio of a bank or a branch. The credit risk grading system is vital to take decisions both at the pre-sanction stage as well as post-sanction stage.

At the pre-sanction stage, credit grading helps the sanctioning authority to decide whether to lend or not to lend, what should be the loan price, what should be the extent of exposure, what should be the appropriate credit facility, what are the various facilities, what are the various risk mitigation tools to put a cap on the risk level.

At the post-sanction stage, the bank can decide about the depth of the review or renewal, frequency of review, periodicity of the grading, and other precautions to be taken.

Having considered the significance of credit risk grading, it becomes imperative for the banking system to carefully develop a credit risk grading model which meets the objective outlined above.

In 1993, Bangladesh Bank as suggested by Financial Sector Reform Project (FSRP) first made the first regulatory move to introduce best practices in this area and directed to use Credit Risk Grading system in the Banking Sector of Bangladesh under the caption "Lending Risk Analysis $(L R A)^{\prime \prime}$ for all lending exposures undertaken by a bank in excess of Tk.10 Million. The Banking sector since then has changed a lot as credit culture has been shifting towards a more professional and standardized Credit Risk Management approach. However, the LRA manual suffers from a lot of subjectivity, sometimes creating confusion to the lending Bankers in terms of selection of credit proposals on the basis of risk exposure.

The LRA forced banks to take a systemic approach towards risk analysis. LRA however made no attempt to introduce a Risk Grading System (RGS) for unclassified accounts.

Credit Risk Grading system is a dynamic process and various models are followed in different countries \& different organizations for measuring credit risk. The risk grading system changes in line with business complexities. A more effective credit risk grading process needs to be introduced in the Banking Sector of Bangladesh to make the credit risk grading mechanism easier to implement.

With the world moving towards Basle II the need to introduce a Risk Grading System (RGS) for the industry is essential. Meanwhile, keeping the above objective in mind, the Lending Risk Analysis Manual (under FSRP) of Bangladesh Bank has been amended, developed and reproduced in the name of "Credit Risk Grading Manual" that was made mandatory in 2003. Bangladesh Bank provided guidelines for credit risk management of Banks wherein it 
recommended, interalia, the introduction of Risk Grade Score Card for risk assessment of credit proposals.

Since the two credit risk models were in vogue, the Governing Board of Bangladesh Institute of Bank Management (BIBM) under the chairmanship of the Governor, Bangladesh Bank decided that an integrated Credit Risk Grading Model be developed incorporating the significant features of the above mentioned models with a view to render a need based simplified and user friendly model for application by the Banks and financial institutions in processing credit decisions and evaluating the magnitude of risk involved therein.

The Credit Risk Grading Manual has taken into consideration the necessary changes required in order to correctly assess the credit risk environment in the Banking industry. This manual has also been able to address the limitations prevailed in the LRA Manual. The Credit Risk Management module in CRMG, for the first time, introduced the requirement of grading unclassified accounts. The CRMG however, was not detailed enough for banks to fully implement a RGS. Therefore in January 2004, BIBM was instructed by Governor of Bangladesh Bank to produce a Credit Risk Grading Manual (CRGM) based on the Core Risks Management Guidelines. BIBM constituted a Focus Group for this purpose. The CRGM was completed and submitted to BB in Sept '04.

CRGM was reviewed by a Industry Review Group (IRG) consisting of members from NCBs, PCBs and FCBs involved specifically in the credit approval and corporate banking functions. The IRG met a number of times in august and September 2005 and gave their recommendations. These were discussed and suitable amendments made in the Guidelines.

All Banks should adopt a credit risk grading system outlined in this manual. Risk grading is a key measurement of a Bank's asset quality, and as such, it is essential that grading is a robust process. The CRGM is a mandatory replacement of the LRA and is applicable for all exposures (irrespective of amount) other than those covered under Consumer and Small Enterprises Financing Prudential Guidelines and also under The Short-Term Agricultural and Micro - Credit.

\subsubsection{Definition of Credit Risk Grading:}

- The Credit Risk Grading (CRG) is a collective definition based on the pre-specified scale and reflects the underlying credit-risk for a given exposure.

- A Credit Risk Grading deploys a number/ alphabet/ symbol as a primary summary indicator of risks associated with a credit exposure.

- Credit Risk Grading is the basic module for developing a Credit Risk Management system.

\subsubsection{Functions of Credit Risk Grading:}


Well-managed credit risk grading systems promote bank safety and soundness by facilitating informed decision-making. Grading systems measure credit risk and differentiate individual credits and groups of credits by the risk they pose. This allows bank management and examiners to monitor changes and trends in risk levels. The process also allows bank management to manage risk to optimize returns.

\subsubsection{Use of Credit Risk Grading:}

- $\quad$ The Credit Risk Grading matrix allows application of uniform standards to credits to ensure a common standardized approach to assess the quality of individual obligor, credit portfolio of a unit, line of business, the branch or the Bank as a whole.

- $\quad$ As evident, the CRG outputs would be relevant for individual credit selection, wherein either a borrower or a particular exposure/facility is rated. The other decisions would be related to pricing (credit-spread) and specific features of the credit facility. These would largely constitute obligor level analysis.

- $\quad$ Risk grading would also be relevant for surveillance and monitoring, internal MIS and assessing the aggregate risk profile of a Bank. It is also relevant for portfolio level analysis.

\subsubsection{Number and Short Name of Grades used in CRG :}

- The CRG scale consists of 08(eight) Categories with short names and numbers are provided below :

Table 6.2: Grades used in CRG

\begin{tabular}{c|c|c|}
\hline Grading & Short Name & Number \\
\hline Superior & SUP & 1 \\
\hline Good & GD & 2 \\
\hline Acceptable & ACCPT & 3 \\
\hline Marginal/ Watch List & MG/ WL & 4 \\
\hline Special Mention & SM & 5 \\
\hline Sub Standard & SS & 6 \\
\hline Doubtful & DF & 7 \\
\hline Bad \& Loss & BL & 8 \\
\hline
\end{tabular}




\section{Credit Risk Grading Definition:}

A clear definition of the different categories of Credit Risk Grading is given as follows:

- $\quad$ Superior (SUP) - 1 :

- Credit facilities, which are fully secured i.e. fully cash covered.

- Credit facilities fully covered by government guarantee.

- Credit facilities fully covered by the guarantee of a top tier international Bank.

- $\operatorname{Good}(\mathrm{GD})-2$ :

- Strong repayment capacity of the borrower.

- The borrower has excellent liquidity and low leverage.

- The company demonstrates consistently strong earnings and cash flow.

- Borrower has well established, strong market share.

- Very good management skill \& expertise.

- All security documentation should be in place.

- Credit facilities fully covered by the guarantee of a top tier local Bank.

- Aggregate Score of 85 or greater based on the Risk Grade Score Sheet.

- $\quad$ Acceptable (ACCPT) - 3 :

- These borrowers are not as strong as GOOD Grade borrowers, but still demonstrate consistent earnings, cash flow and have a good track record.

- Borrowers have adequate liquidity, cash flow and earnings.

- Credit in this grade would normally be secured by acceptable collateral (1st charge over inventory / receivables / equipment / property).

- Acceptable management.

- Acceptable parent/sister company guarantee.

- Aggregate Score of 75-84 based on the Risk Grade Score Sheet.

- Marginal/ Watch List (MG/WL) - 4:

- This grade warrants greater attention due to conditions affecting the borrower, the industry or the economic environment.

- These borrowers have an above average risk due to strained liquidity, higher than normal leverage, thin cash flow and/or inconsistent earnings.

- Weaker business credit \& early warning signals of emerging business credit detected.

- The borrower incurs a loss.

- Loan repayments routinely fall past due.

- Account conduct is poor, or other untoward factors are present.

- Credit requires attention. 
- Aggregate Score of 65-74 based on the Risk Grade Score Sheet.

- $\quad$ Special Mention (SM) - 5 :

- This grade has potential weaknesses that deserve management's close attention. If left uncorrected, these weaknesses may result in a deterioration of the repayment prospects of the borrower.

- Severe management problems exist.

- Facilities should be downgraded to this grade if sustained deterioration in financial condition is noted (consecutive losses, negative net worth, excessive leverage).

- An Aggregate Score of 55-64 based on the Risk Grade Score Sheet.

- $\quad$ Sub Standard (SS) - 6 :

- Financial condition is weak and capacity or inclination to repay is in doubt.

- These weaknesses jeopardize the full settlement of loans.

- Bangladesh Bank criteria for sub-standard credit shall apply.

- An Aggregate Score of 45-54 based on the Risk Grade Score Sheet.

- $\quad$ Doubtful (DF) - 7 :

- Full repayment of principal and interest is unlikely and the possibility of loss is extremely high.

- However, due to specifically identifiable pending factors, such as litigation, liquidation procedures or capital injection, the asset is not yet classified as Bad \& Loss.

- Bangladesh Bank criteria for doubtful credit shall apply.

- An Aggregate Score of 35-44 based on the Risk Grade Score Sheet.

- $\quad$ Bad \& Loss (BL) - 8 :

- Credit of this grade has long outstanding with no progress in obtaining repayment or on the verge of wind up/liquidation.

- Prospect of recovery is poor and legal options have been pursued.

- Proceeds expected from the liquidation or realization of security may be awaited. The continuance of the loan as a bankable asset is not warranted, and the anticipated loss should have been provided for.

- This classification reflects that it is not practical or desirable to defer writing off this basically valueless asset even though partial recovery may be affected in the future. Bangladesh Bank guidelines for timely write off of bad loans must be adhered to. Legal procedures/suit initiated. 
- Bangladesh Bank criteria for bad \& loss credit shall apply.

- An Aggregate Score of less than 35 based on the Risk Grade Score Sheet.

\subsubsection{Credit Risk Grading Determining Process :}

The following step-wise activities outline the detail process for arriving at credit risk grading:

Step -1 : Identify all the Principal Risk Components

Credit risk for counterparty arises from an aggregation of the following :

- Financial Risk.

- Business/Industry Risk.

- Management Risk.

- Security Risk.

- Relationship Risk.

Fig 6.1: The above Risk Components can be divided as follows :

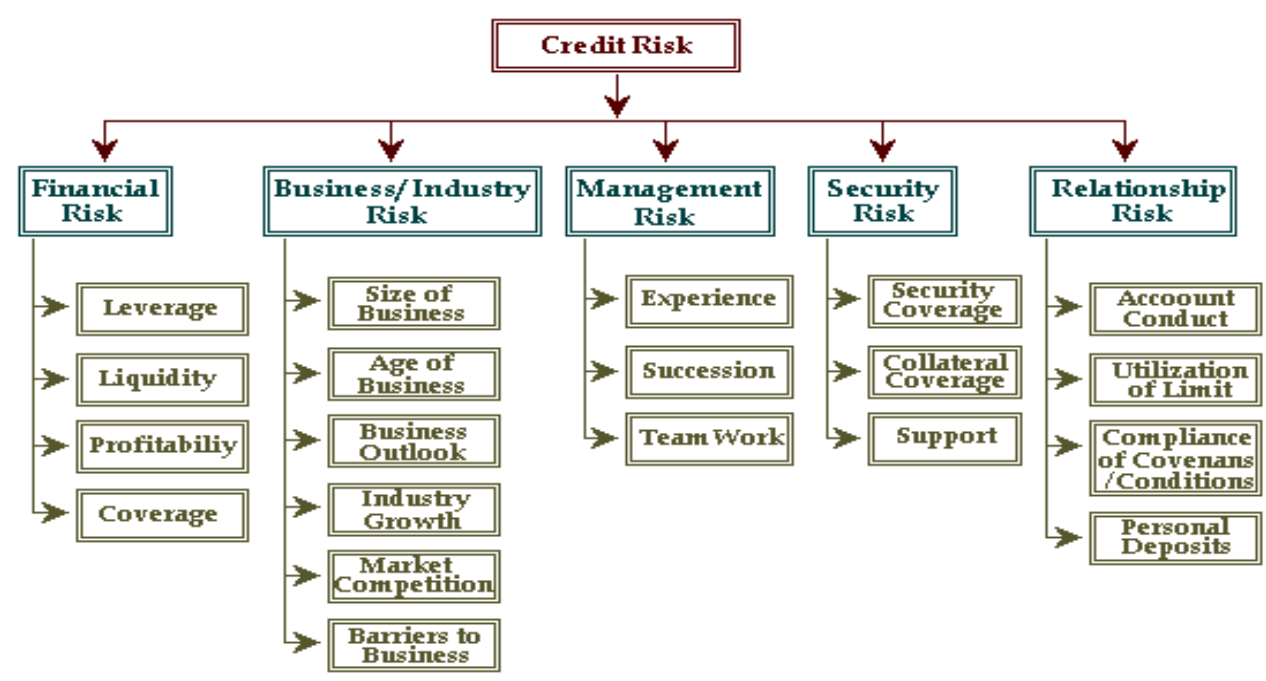

Each of the above mentioned key risk areas require to be evaluated and aggregated to arrive at an overall risk grading measure.

\section{Evaluation of Financial Risk :}

Risk that counterparties will fail to meet obligation due to financial distress. This typically entails analysis of financials i.e. analysis of leverage, liquidity, profitability \& interest coverage ratios. To conclude, this capitalizes on the risk of high leverage, poor liquidity, low profitability \& insufficient cash flow.

\section{Evaluation of Business/Industry Risk :}


Risk that adverse industry situation or unfavorable business condition will impact borrowers' capacity to meet obligation. The evaluation of this category of risk looks at parameters such as business outlook, size of business, industry growth, market competition \& barriers to entry/exit. To conclude, this capitalizes on the risk of failure due to low market share $\&$ poor industry growth.

\section{Evaluation of Management Risk :}

Risk that counterparties may default as a result of poor managerial ability including experience of the management, its succession plan and team work.

\section{Evaluation of Security Risk :}

Risk that the bank might be exposed due to poor quality or strength of the security in case of default. This may entail strength of security \& collateral, location of collateral and support.

\section{Evaluation of Relationship Risk :}

These risk areas cover evaluation of limits utilization, account performance, conditions/covenants compliance by the borrower and deposit relationship.

\section{Step -2: Allocate weights to Principal Risk Components}

According to the importance of risk profile, the following weights are proposed for corresponding principal risks:

Table6.3: Allocated weights to different parameters

\section{Principal Risk Components}

- Financial Risk

- Business/Industry Risk

- Management Risk

- Security Risk

- Relationship Risk

TOTAL

\section{Weight}

$50 \%$

$18 \%$

$12 \%$

$10 \%$

$10 \%$

$100 \%$ 


\section{Step -3 : Establish the Key Parameters}

According to the importance of risk profile, the following weights are proposed for corresponding principal risks:

Table6.4: Key parameters of different risks

Principal Risk Components

- Financial Risk

- Business/ Industry Risk

- Management Risk

- Security Risk

- Relationship Risk

\section{Key Parameters}

Leverage, Liquidity, Profitability \& Coverage ratio

Size of Business, Age of Business, Business Outlook, Industry Growth, Competition \& Barriers to Business

Experience, Succession \& Team Work.

Security Coverage, Collateral Coverage and Support.

Account Conduct, Utilization of Limit, Compliance of covenants/conditions \& Personal Deposit.

\section{Step -4 : Establish the Key Parameters}

According to the importance of risk profile, the following weights are proposed for corresponding principal risks:

Table 6.5: Risk Components

\begin{tabular}{|l|l|c|c|}
\hline $\begin{array}{c}\text { Principal Risk } \\
\text { Components }\end{array}$ & Key Parameters & \multicolumn{2}{|c|}{ Weight } \\
\hline - Financial Risk & $\rightarrow$ Leverage & Individual & Total \\
\hline & $\rightarrow$ Liquidity & $15 \%$ & \\
\hline & $\rightarrow$ Profitability & $15 \%$ & $50 \%$ \\
\hline & $\rightarrow$ Coverage & $15 \%$ & \\
\hline
\end{tabular}


- Business/Industry

Risk

Size of Business

$5 \%$

- Age of Business

$3 \%$

$18 \%$

๑ Business Outlook

$3 \%$

๑ Industry Growth

$3 \%$

- Market Competition

$2 \%$

$\rightarrow$ Entry/ Exit Barriers

$2 \%$

- Management Risk

๑ Experience

$5 \%$

- Succession

$4 \%$

$12 \%$

D Team Work.

$3 \%$

- Security Risk

- Security Coverage

$4 \%$

- Collateral Coverage

$4 \%$

$10 \%$

D Support

$2 \%$

- Relationship Risk

כ Account Conduct

$5 \%$

- Utilization of Limit

$2 \%$

$\rightarrow$ Compliance of

$2 \%$

$10 \%$ covenants/conditions

$\rightarrow$ Personal Deposit

$1 \%$

\section{Step -5: Input Data to arrive at the Score on the Key Parameters}

After the risk identification \& weight assignment process (as mentioned above), the next steps will be to input actual parameter in the score sheet to arrive at the scores corresponding to the actual parameters.

The CRG Manual (CRGM) provided by Bangladesh Bank also includes a well programmed MS Excel based Credit Risk Scoring Sheet to arrive at a total score on each borrower. The excel program requires inputting data accurately in particular cells for input and will automatically calculate the risk grade for a particular borrower based on the total score obtained.

\section{Step -6 : Arrive at the Credit Risk Grading based on Total Score Obtained}


The following is the proposed Credit Risk Grade matrix based on the total score obtained by an obligor :

Table 6.6: Categorization of Risks

\begin{tabular}{|c|c|c|c|}
\hline Number & Risk Grading & Short Name & Score \\
\hline \multirow[t]{2}{*}{1} & \multirow[t]{2}{*}{ Superior } & \multirow[t]{2}{*}{ SUP } & $\begin{array}{l}\text { 100\% Cash Covered } \\
\text { Government Guarantee }\end{array}$ \\
\hline & & & $\begin{array}{l}\text { International } \\
\text { Guarantee }\end{array}$ \\
\hline 2 & Good & GD & $85+$ \\
\hline 3 & Acceptable & ACCPT & $75-84$ \\
\hline 4 & $\begin{array}{l}\text { Marginal/ Watch } \\
\text { List }\end{array}$ & MG/WL & $65-74$ \\
\hline 5 & Special Mention & SM & $55-64$ \\
\hline 6 & Sub-Standard & SS & $45-54$ \\
\hline 7 & Doubtful & DF & $35-44$ \\
\hline 8 & Bad \& Loss & $\mathrm{BL}$ & $<35$ \\
\hline
\end{tabular}

\subsubsection{Credit Risk Grading Process :}

- $\quad$ Credit Risk Grading should be completed by a Bank for all exposures (irrespective of amount) other than those covered under Consumer and Small Enterprises Financing Prudential Guidelines and also under the Short-Term Agricultural and Micro Credit.

- $\quad$ For Superior Risk Grading (SUP-1) the score sheet is not applicable. This will be guided by the criterion mentioned for superior grade account i.e. 100\% cash covered, covered by government $\&$ bank guarantee.

- $\quad$ Credit Risk Grading Matrix would be useful in analyzing credit proposal, new or renewal for regular limits or specific transactions, if basic information on a borrowing client to determine the degree of each factor is a) readily available, b) current, c) dependable, and d) parameters/risk factors are assessed judiciously and objectively. The Relationship Manager as per Data Collection Checklist should collect required information. 
- $\quad$ Relationship manager should ensure to correctly fill up the Limit Utilization Form in order to arrive at a realistic earning status for the borrower.

- $\quad$ Risk factors are to be evaluated and weighted very carefully, on the basis of most up-to-date \& reliable data and complete objectivity must be ensured to assign the correct grading. Actual parameter should be inputted in the Credit Risk Grading Score Sheet.

- $\quad$ Credit risk grading exercise should be originated by Relationship Manager and should be an on-going and continuous process. Relationship Manager shall complete the Credit Risk Grading Score Sheet and shall arrive at a risk grading in consultation with a Senior Relationship Manager and document it as per Credit Risk Grading Form, which shall then be concurred by the Credit Officer in consultation with a Senior Credit Officer.

- $\quad$ All credit proposals whether new, renewal or specific facility should consist of a) Data Collection Checklist, b) Limit Utilization Form c) Credit Risk Grading Score Sheet, and d) Credit Risk Grading Form.

- $\quad$ The credit officers then would pass the approved Credit Risk Grading Form to Credit Administration Department and Corporate Banking/Line of Business/Recovery Unit for updating their MIS/record.

- The appropriate approving authority through the same Credit Risk Grading Form shall approve any subsequent change/revision i.e. upgrade or downgrade in credit risk grade.

\subsection{EARLY ALERT \& COLLECTION MANAGEMENT}




\subsubsection{Early Alert System:}

An Early Alert Account is one that has risks or potential weaknesses of a material nature requiring monitoring, supervision, or close attention by management.

If these weaknesses are left uncorrected, they may result in deterioration of the repayment prospects for the asset or in the Bank's credit position at some future date with a likely prospect of being downgraded to CG 5 or worse (Impaired status), within the next twelve months.

Early identification, prompt reporting and proactive management of Early Alert Accounts are prime credit responsibilities of all Relationship Managers and must be undertaken on a continuous basis. An Early Alert report (Appendix) should be completed by the RM and sent to the approving authority in CRM for any account that is showing signs of deterioration within seven days from the identification of weaknesses. The Risk Grade should be updated as soon as possible and no delay should be taken in referring problem accounts to the CRM department for assistance in recovery.

Despite a prudent credit approval process, loans may still become troubled. Therefore, it is essential that early identification and prompt reporting of deteriorating credit signs be done to ensure swift action to protect the Bank's interest. The symptoms of early alert shown in Appendix are by no means exhaustive and hence, if there are other concerns, such as a breach of loan covenants or adverse market rumors that warrant additional caution, an Early Alert report should be raised.

Moreover, regular contact with customers will enhance the likelihood of developing strategies mutually acceptable to both the customer and the Bank. Representation from the Bank in such discussions should include the local legal adviser when appropriate.

An account may be reclassified as a Regular Account from Early Alert Account status when the symptom, or symptoms, causing the Early Alert classification have been regularized or no longer exist. The concurrence of the CRM approval authority is required for conversion from Early Alert Account status to Regular Account status.

Relationship Manager shall ensure that call/ inspection are regularly made on the Clients and documented the outcome of the visit in the form of call/visit report.

Call reports shall be analyzed to ensure that the affairs of the business of the borrower is being run on expected line and there is no material change in the status of the borrower.

Relationship Manager regularly monitors performance of the customer's business as well as reputation, status and prepares a status and prepares a status report.

Relationship Manager prepares Early Alert Report within 07(Seven) days after identification of weakness and sign of deterioration 


\subsubsection{Recovery:}

The Recovery Department directly manages accounts with sustained deterioration i.e. a Risk Rating of Sub Standard (6) or worse. Banks may wish to transfer EXIT accounts graded 4-5 to the Recovery Unit for efficient exit based on recommendation of CRM and Corporate Banking. Whenever an account is handed over from Relationship Management to Recovery Unit, a Handover/Downgrade Checklist is completed.

Down grading process should be done immediately and should not be postponed until the annual review process.

The Primary Functions of Recovery Units are:

- Determine Account Action Plan/Recovery Strategy.

- Pursue all options to maximize recovery, including placing customers into receivership or liquidation as appropriate.

- Ensure adequate and timely loan loss provisions are made based on actual and expected losses.

- Regular review of grade 6 or worse accounts.

- Management of classified loans and special mention.

- Accounts and related works writing off B/L loans with the approval off the Board.

The management of problem loans (NPLs) must be a dynamic process, and the associated strategy together with the adequacy of provisions must be regularly reviewed. A process should be established to share the lessons learned from the experience of credit losses in order to update the lending guidelines.

\subsubsection{NPL Account Management:}

All NPLs should be assigned to an Account Manager within the RU, who is responsible for coordinating and administering the action plan/recovery of the account, and should serve as the primary customer contact after the account is downgraded to substandard. Whilst some assistance from Corporate Banking/ Relationship Management may be sought, it is essential that the autonomy of the RU be maintained to ensure appropriate recovery strategies are implemented.

\subsubsection{Account Transfer Procedures:}

Within 7 days of an account being downgraded to substandard (grade 6), a Request for Action, RFA (Annexure - 10) and a handover/downgrade checklist (Annexure - 9) should be completed by the RM and 
forwarded to RU for acknowledgment. The account should be assigned to an account manager within the $\mathrm{RU}$, who should review all documentation, meet the customer, and prepare a Classified Loan Review Report, CLR (Annexure - 11) within 15 days of the transfer. The CLR should be approved by the Head of Credit, and copied to the Head of Corporate Banking and to the Branch/office where the loan was originally sanctioned. This initial CLR should highlight any documentation issues, loan structuring weaknesses, proposed workout strategy, and should seek approval for any loan loss provisions that are necessary.

Recovery Units should ensure that the following is carried out when an account is classified as Sub Standard or worse:

- Facilities are withdrawn or repayment is demanded as appropriate. Any drawings or advances should be restricted, and only approved after careful scrutiny and approval from appropriate executives within CRM.

- $\mathrm{CIB}$ reporting is updated according to Bangladesh Bank guidelines and the borrower's Risk Grade is changed as appropriate.

- Loan loss provisions are taken based on Force Sale Value (FSV).

- Loans are only rescheduled in conjunction with the Large Loan Rescheduling guidelines of Bangladesh Bank. Any rescheduling should be based on projected future cash flows, and should be strictly monitored.

- Prompt legal action is taken if the borrower is uncooperative.

\subsubsection{Non-Performing Loan (NPL) Monitoring:}

On a quarterly basis, a Classified Loan Review (CLR) should be prepared by the RU Account Manager to update the status of the action/recovery plan, review and assess the adequacy of provisions, and modify the bank's strategy as appropriate. The Head of Credit should approve the CLR for NPLs up to $15 \%$ of the banks capital, with MD/CEO approval needed for NPLs in excess of $15 \%$. The CLR's for NPLs above $25 \%$ of capital should be approved by the MD/CEO, with a copy received by the Board.

\subsubsection{NPL Provisioning and Write-off:}

The guidelines established by Bangladesh Bank for CIB reporting, provisioning and write off of bad and doubtful debts, and suspension of interest should be followed in all cases. These requirements are the minimum, and Banks are encouraged to adopt more stringent provisioning/write off policies. Regardless 
of the length of time a loan is past due, provisions should be raised against the actual and expected losses at the time they are estimated. The approval to take provisions, write offs, or release of provisions/upgrade of an account should be restricted to the Head of Credit or MD/CEO based on recommendation from the Recovery Unit. The Request for Action (RFA) or CLR reporting format should be used to recommend provisions, write-offs or release/upgrades.

The RU Account Manager should determine the Force Sale Value (FSV) for accounts grade 6 or worse. Force Sale Value is generally the amount that is expected to be realized through the liquidation of collateral held as security or through the available operating cash flows of the business, net of any realization costs. Any shortfall of the Force Sale Value compared to total loan out standings should be fully provided for once an account is downgraded to grade 7 . Where the customer is not cooperative, no value should be assigned to the operating cash flow in determining Force Sale Value.

Force Sale Value and provisioning levels should be updated as and when new information is obtained, but as a minimum, on a quarterly basis in the CLR.

\subsection{CLASSIFICATION \& PROVISIONING OF LOANS \& ADVANCES:}

In order to strengthen credit discipline and improve the recovery positions of Loans and Advances by the Banks, Bangladesh Bank vide BCD Circular No.34/ 1989 introduced a new system covering loans and advances classification, the suspension of interest due and the making of provisions against potential loan loss.

With a view to further strengthening credit discipline and bring classification and provisioning regulation in line with international standard, a phase wise program for loan classification and provisioning was undertaken by Bangladesh Bank through BCD Circular No. 20/1994. Afterwards, a comprehensive circular, BRPD Circular No. 16/1998 was issued with major amendments in previous circulars with a view to achieving a more specified and simplified system of loan classification and provisioning.

Later on, as part of the process i.e. regarding the changes meanwhile Bangladesh Bank has already introduced "Special Mention Account" vide BRPD Circular No. 02/2005 and 09/2005 for the banks and raise early warning signals for accounts showing first signs of weakness and making appropriate provisioning therein. As a further move towards this end, changes in the formats for classification and provisioning have been made vide BRPD Circular No. 08/2005. Moreover, some changes have been made in the provisioning requirement for Consumer Financing and Small Enterprise Financing.

Meanwhile, in order enable the banks to have all existing instructions on the subject at one place a Master Circular has been issued by Bangladesh Bank vide BRPD Circular No. 05/2006 by incorporating all instructions issued from time to time, which includes a few new instructions as well.

The details of loans and advances classification and provisioning are described below :

\subsubsection{Categories of Loans and Advances:}


All loans and advances are grouped into 04(four) categories as follows :

Fig 6.2: Group of loans and advances

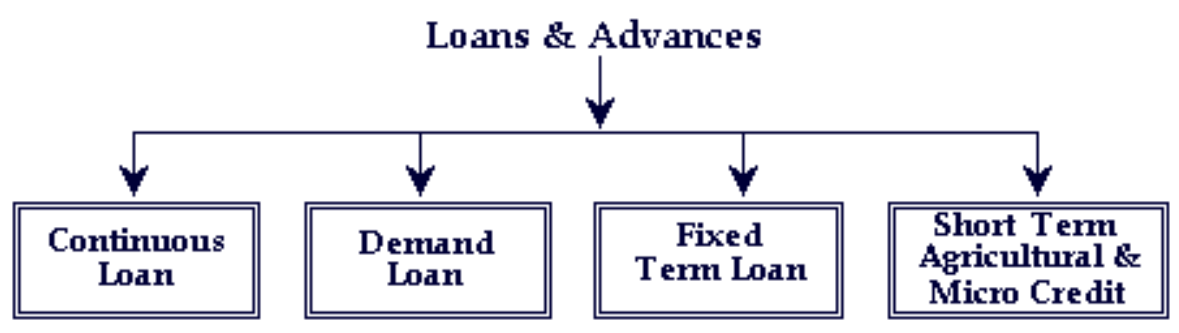

- Continuous Loan: The loan account in which transactions may be made within certain limit and have an expiry date for full adjustment is treated as Continuous Loan. Examples are : Cash Credit, Over Draft, etc.

- $\quad$ Demand Loan : The loans that become repayable on demand by the bank is treated as Demand Loan. If any contingent or any other liabilities are turned to forced loans (i.e. without any prior approval as regular loan) those too will be treated as Demand Loan. Such as Forced LIM, PAD, FDBP, LDBP, IBP, FBP, etc.

- $\quad$ Fixed Term Loan : The loans, which are repayable within a specific time period under a specific repayment schedule are treated as Fixed Term Loans.

- $\quad$ Short-term Agricultural \& Micro Credit : Short-term Agricultural Credit includes the short-term credits as listed under the Annual Credit Programs issued by Agricultural Credit and Special Programs Department (ACSPD) of Bangladesh Bank. Credits in the agricultural sector repayable within 12(twelve) months will also be included therein. Short-term Micro Credit includes any micro credits not exceeding Tk.25,000/- (Taka Twenty Five Thousand) and repayable within 12(twelve) months, be those termed in any names such as Non-agricultural credit, Self-reliant Credit, Weaver's Credit or bank's individual project credit.

\subsubsection{Basis for Loan Classification:}

All loans and advances are grouped into 04(four) categories as follows :

a. Objective Criteria : 


\section{- Past Due/ Overdue :}

- $\quad$ Any Continuous Loan if not repaid/ renewed within the fixed expiry date for repayment will be treated as past due/ overdue from the following day of the expiry date.

- $\quad$ Any Demand Loan if not repaid/ re-scheduled within the fixed expiry date for repayment will be treated as past due/ overdue from the following day of the expiry date.

- In case of any installment(s) or part thereof of a Fixed Term Loan (not over five years) is not repaid within the fixed expiry date, the amount of unpaid installment(s) will be treated as past due/ overdue from the following day of the expiry date.

- In case of any installment(s) or part thereof of a Fixed Term Loan (over five years) is not repaid within the fixed expiry date, the amount of unpaid installment(s) will be treated as past due/ overdue after 06(six) months of the expiry date.

- $\quad$ The Short-term Agricultural and Micro Credit if not repaid/ renewed within the fixed expiry date will be considered as past due/ overdue after 06(six) months of the expiry date.

- $\quad$ All unclassified loans other than Special Mention Account (SMA) will be treated as Standard.

- A Continuous Credit, Demand Loan or a Term Loan which will remain overdue for a period of 90 (ninety) days or more but less than 180 (one eighty) days, will be put into the "Special Mention Account (SMA)" and interest accrued on such loan will be credited to Interest Suspense Account, instead of crediting the same to Income Account. This will help banks to look at accounts with potential problems in a focused manner and it will capture early warning signals for accounts showing first sign of weakness.

Loans under "Special Mention Account (SMA)" will have to be reported to the Credit Information Bureau (CIB) of Bangladesh Bank. However, it is reiterated that loans in the "Special Mention Account (SMA)" will not be treated as default loan for the purpose of section 27KaKa(3) of the Bank Company Act, 1991.

Any Continuous Loan will be classified as :

- "Sub Standard (SS)" if it is past due/ overdue for 06(six) months but less than 09(nine) months.

- "Doubtful (DF)" if it is past due/ overdue for 09(nine) months but less than 12(twelve) months.

- "Bad \& Loss (BL)" if it is past due/ overdue for 12(twelve) months or beyond. 
Any Demand Loan will be classified as :

- "Sub Standard (SS)" if it remains past due/ overdue for 06(six) months or beyond but not over 09(nine) months from the date of claim by the bank or from creation of the loan.

- $\quad$ "Doubtful (DF)" if it remains past due/ overdue for 09(nine) months or beyond but not over 12(twelve) months from the date of claim by the bank or from the date of creation of the loan.

- "Bad \& Loss (BL)" if it remains past due/ overdue for 12(twelve) months or beyond from the date of claim by the bank or from the date of creation of the loan.

In case of any installment(s) or part of installment(s) of Fixed Term Loan is not repaid within the due date, the amount of the unpaid installment(s) will be termed as "Defaulted Installment".

In case of Fixed Term Loans, which are repayable within maximum 05(five) years of time:

- If the amount of "Defaulted Installment" is equal to or more than the amount of installment(s) due within 12(twelve) months, the entire loan will be classified as "Sub Standard (SS)".

- If the amount of "Defaulted Installment" is equal to or more than the amount of installment(s) due within 18(eighteen) months, the entire loan will be classified as "Doubtful (DF)".

- If the amount of "Defaulted Installment" is equal to or more than the amount of installment(s) due within 24(twenty four) months, the entire loan will be classified as "Bad \& Loss (BL)".

In case of Fixed Term Loans, which are repayable more than 05(five) years of time:

- If the amount of "Defaulted Installment" is equal to or more than the amount of installment(s) due within 06(six) months, the entire loan will be classified as "Sub Standard (SS)".

- If the amount of "Defaulted Installment" is equal to or more than the amount of installment(s) due within 12(twelve) months, the entire loan will be classified as "Doubtful (DF)".

- If the amount of "Defaulted Installment" is equal to or more than the amount of installment(s) due within 18(eighteen) months, the entire loan will be classified as "Bad \& Loss (BL)". 
Explanation: If any Fixed Term Loan is repayable on monthly installment basis, the amount of installments due within 06(six) month will be equal to the sum of 06(six) monthly installments. Similarly, if the loan is repayable on quarterly installment basis, the amount of installments due within 06(six) month will be equal to the sum of 02 (two) quarterly installments.

\section{b. Qualitative Judgment (QJ) :}

If any uncertainty or doubt arises in respect of recovery of any Continuous loan, Demand Loan or Fixed Term Loan, the same will have to be classified on the basis of qualitative judgment be it classifiable or not on the basis of objective criteria. If any situational changes occur in the stipulations in terms of which the credit was extended or if the capital of the borrower is impaired due to adverse conditions or if the value of the securities decreases or if the recovery of the credit becomes uncertain due to any other unfavorable situation, the credit will have to be classified on the basis of qualitative judgment.

Besides, if any loan is illogically or repeatedly re-scheduled or the norms of rescheduling are violated or instances of (propensity to) frequently exceeding the credit limit are noticed or legal action is lodged for recovery of the credit or the credit extended without approval of the competent authority, it will have to be classified on the basis of qualitative judgment.

Despite the probability of any credit being affected due to the reasons stated above or for any other reasons, if there exists any hope for change of the existing condition by resorting to proper steps, the credit, on the basis of qualitative judgment, will be classified as "Sub Standard (SS)". But, even if after resorting to proper steps, there exists no certainty of total recovery of the Bank's dues, it will be classified as "Doubtful (DF)" and even after exerting the all-out effort, there exists no chance of recovery, it will be classified as "Bad \& Loss (BL)" on the basis of qualitative judgment.

The concerned bank will classify on the basis of qualitative judgment and can declassify the credits if quality improvement does occur.

But if any loan is classified by the Inspection team of Bangladesh Bank, the same can be declassified with the approval of the Board of Directors of the respective bank. However, before placing such case to the Board of Directors, the MD/ CEO and the 
respective Branch Manager of the Bank shall have to certify that the terms and conditions of declassification have been duly fulfilled by the borrowers.

The Bank will have to inform such declassifications to the Department of Banking Inspection/ concerned offices of Bangladesh Bank within 15(fifteen) days of such decision taken by the Board of Directors. Bangladesh Bank will examine these matters on case-to-case basis and if any irregularities/ deviations is detected, necessary legal action will be taken against the concerned officials.

\section{c. Accounting of the Interest of Classified Loans \& Advances :}

If any loan or advance is classified as "Sub Standard (SS)" and "Doubtful (DF)", interest accrued on such loan will be credited to "Interest Suspense Account", instead of crediting the same to Income Account. In case of re-scheduled loans the unrealized interest, if any, will be credited to "Interest Suspense Account", instead of crediting the same to Income Account.

As soon as any loan or advance is classified as "Bad \& Loss (BL)", charging interest in the same account will cease. In case of filing a law-suit for recovery of such loan, interest for the period till filing of the suit can be charged in the loan account has to be preserved in the "Interest Suspense Account". If any interest is charged on any "Bad \& Loss (BL)" account for any other special reason, the same will preserved in the "Interest Suspense Account".

If classified loan or part of it is recovered i.e. real deposit is effected in the loan account, first the interest charged and not charged is to be recovered from the said deposit and the principal to be adjusted afterwards.

\section{d. Maintenance of Provision :}

- Banks require to maintain General Provision in respect of the Unclassified loans \& Advances in the following manner : 
Table 6.7: Required Provision Of Different Classification Group

Type of Classification

- Standard

(other than loans under Small Enterprise and Consumer Financing)

- Unclassified Small Enterprise Financing

- Unclassified Consumer Financing

- Unclassified Housing Financing \& Loans for Professionals to set Business Consumer Financing Scheme

- Special Mention Account (SMA)
Required

Provision

@1\%

@2\%

@ 5\%

@2\%

@ 5\%

- Banks require to maintain Provision in respect of Classified Continuous, Demand and Fixed Term loans in the following manner

Table 6.8: Required Provision of Different Classification Group

Type of Classification
Required

Provision

- Sub Standard (SS)

- Doubtful (DF)

- $\quad$ Bad \& Loss (BL)
@20\%

@ 50\%

@100\%

- Banks require to maintain Provision in respect of Short-term Agricultural and Micro Credits in the following rates :

Table 6.9: Required Provision of Different Classification Group

Type of Classification

- All Credits except Bad \& Loss (BL)
Required

Provision

@ 5\% 
e. Base for Provision :

Provision will be maintained at the above rate on balance to be ascertained by deducting the amount kept in "Interest Suspense Account" and Value of Eligible Securities from the Outstanding Balance of the Classified accounts.

\section{Eligible Securities:}

If the definition of "Eligible Securities" as mentioned hereinabove the following securities will be included as "Eligible Securities" in determining base for provision :

- $100 \%$ of Deposit under lien against the loan.

- $100 \%$ of the Value of Government Bond/Savings Certificates under lien.

- $100 \%$ of Value of Guarantee given by Government or Bangladesh Bank.

- $100 \%$ of Market Value of Gold or Gold Ornaments pledged with the Bank.

- $\mathbf{5 0 \%}$ of Market Value of Easily Marketable Commodities kept under control of the Bank.

- Maximum 50\% of the Market Value of Land and Building mortgaged with the Bank.

- $50 \%$ of the Average Market Value for the last $06($ six) months or $50 \%$ of the Face Value, whichever is less, of the Shares traded in the Stock Exchanges.

f. Determination of Market Value of the Eligible Securities :

In determining the Market Value of Easily Marketable Commodities, Land \& Building as banks are advised by the Bangladesh Bank to follow the instructions mentioned below :

- Easily Marketable Commodities mean pledged easily encashable/ saleable goods that remain under full control of the Bank. However, while the concerned Bank Branch official will conduct periodic inspection to verify as to whether issues such as the suitability of goods for use, expiry period, appropriateness of documentary evidences, up-to-date insurance coverage, same will have to be assessed by the professional assessor from time to time.

- For Land \& Building, banks have to ensure whether title documents are in order and concerned land and building will have to be valued by the professional valuation firm along with completion of proper documentation in favor the bank. In absence of Professional valuation firm, certificate in favor of such valuation will 
have to be collected from specialized engineer. Nevertheless, temporary house including Tin-shed structure shall not be shown as building.

- In order to facilitate the on-site inspection by Department of Bank Inspection of Bangladesh Bank is also advised to maintain complete statement of eligible securities on a separate sheet in the concerned loan file. Information such as description of eligible securities, their assessment by recognized firm, marketability of the commodity, control of the bank and reasons for considering eligible securities etc. have to be included in that sheet.

\section{g. Period of Conducting Classification :}

In terms of above policies Banks requires to conduct their classification activities on quarterly basis. 


\section{CHAPTER 7}

\section{EFFECTS OF MANAGEMENT \\ OF CREDIT RISKS IN \\ JAMUN BANK LTD.}

Identifying and assessing credit risk is essentially a first step in managing it effectively. As per Financial performance of JBL it is observed that the Profit After Tax, Earnings per Share (EPS), Net Assets per Share (NAV) turned down significantly over the last couple of years i.e. in 2006 and 2012 with respect to the previous ones, though the Deposit and Credits Portfolio, Total Income, Operating Profit, Number of Branches increased during the said period.

The reasons behind the fact were during the period under reference a sizeable amount of Bank's credits got classified adversely as those were sanctioned and disbursed with stacks of defects and flaws in the previous years which was the early stage of the Bank.

Meanwhile, recently the Bank has been able to improve the quality of its assets significantly through efficient Management of Credit Risks, which are mentioned below :

- The Bank has been able to recover around Tk.212.50 million in cash out of its adversely classified loans and advances during 2013 up to 31st instance of August. 
Consequently, the percentage of Classified and Non performing loans and advances of Total Loans \& Advances has gone down to 3.25\% as on 31st August, 2013 from $5.06 \%$ as on 31st December, 2012, which can be termed as remarkable progress.

- The Bank has successfully developed an integrated and well-coordinated system of Analysis, Appraisal and Sanction of Credits through its Credit Operation Division followed by proper and strict Control and Disbursement process through its Credit Administration Division backed by fully automated structure.

- Notable that almost entire classified loans and advances were extended at the initial stage of the Bank i.e. from 2001 to 2005, which became classified during the last couple of years and thus Bank suffered adversely in 2006 and 2012. While, the bulk of the recently sanctioned credits sound good. Consequently, the Bank has been able to mark an upward trend in its operational and financial performance.

- The bank is a way of establishing proper governance structure risk and returns are evaluated with a view to producing sustainable revenues, reducing volatility in earnings and enhancing value to shareholders.

- The Bank also pursues an effective internal control system by establishing systems and procedures for scrutinizing the transactions periodically encompassing key back-up supports and commissioning regular contingency plan.

\section{PROBLEMS IN MANAGEMENT OF CREDIT RISKS IN JAMUNA BANK LTD. :}

JBL faces following Problems in Management of Credit Risks:

- Competitive Banking Market: Different kinds of commercial Banks, both local and foreign are serving in our commercial Banking Market. Therefore, competing with other bank for weak credit management it is hard to survive. Besides, the whole banking sector in our country is undergoing a critical stage due to political unrest and depressed economic condition.

- Credit Sales: Now a day, Businessperson is bound for credit sales to increase their sales in the competitive market. Resultantly, Business organizations need less working capital and Banking companies are loosing their opportunities to invest in Business organization. 
- Lack of Marketing Activities: The promotional activities and marketing of different products of JBL are not sufficient for catering its services to the public or the Business organization.

- Lack of Scope : Since the bulk of the Deposits, Capital and investable funds have already been employed in different loans and advances out of which a large portion have been stuck up as classified and non performing assets. Resultantly, under the prevailing condition it is difficult to increase the credit portfolio and ensure the proper Management of Credit Risks.

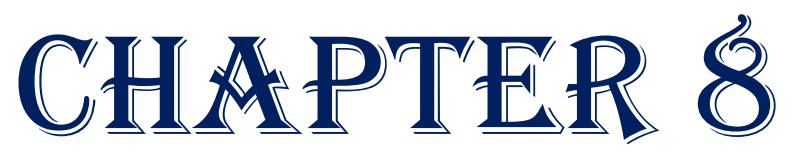




\section{BASEL II ACCORD}

Basel II is the second of the Basel Accords, which are recommendations on banking laws and regulations issued by the Basel Committee on Banking Supervision. Its purpose was initially published in June 2004, is to create an international standard that banking regulators can use when creating regulations about how much capital banks need to put aside to guard against the types of financial and operational risks banks face. Advocates of Basel II believe that such an international standard can help protect the international financial system from the types of problems that might arise should a major bank or a series of banks collapse. In practice, Basel II attempts to accomplish this by setting up rigorous risk and capital management requirements designed to ensure that a bank holds capital reserves appropriate to the risk the bank exposes itself to through its lending and investment practices. Generally speaking, these rules mean that the greater risk to which the bank is exposed, the greater the amount of capital the bank needs to hold to safeguard its solvency and overall economic stability.

\section{The final version of Basell II aims at :}

- Ensuring that capital allocation is more risk sensitive;

- Separating operational risk from credit risk, and quantifying both;

- Attempting to align economic and regulatory capital more closely to reduce the scope for regulatory arbitrage; 
Fig 8.1: Structure of New Basel II Accord:

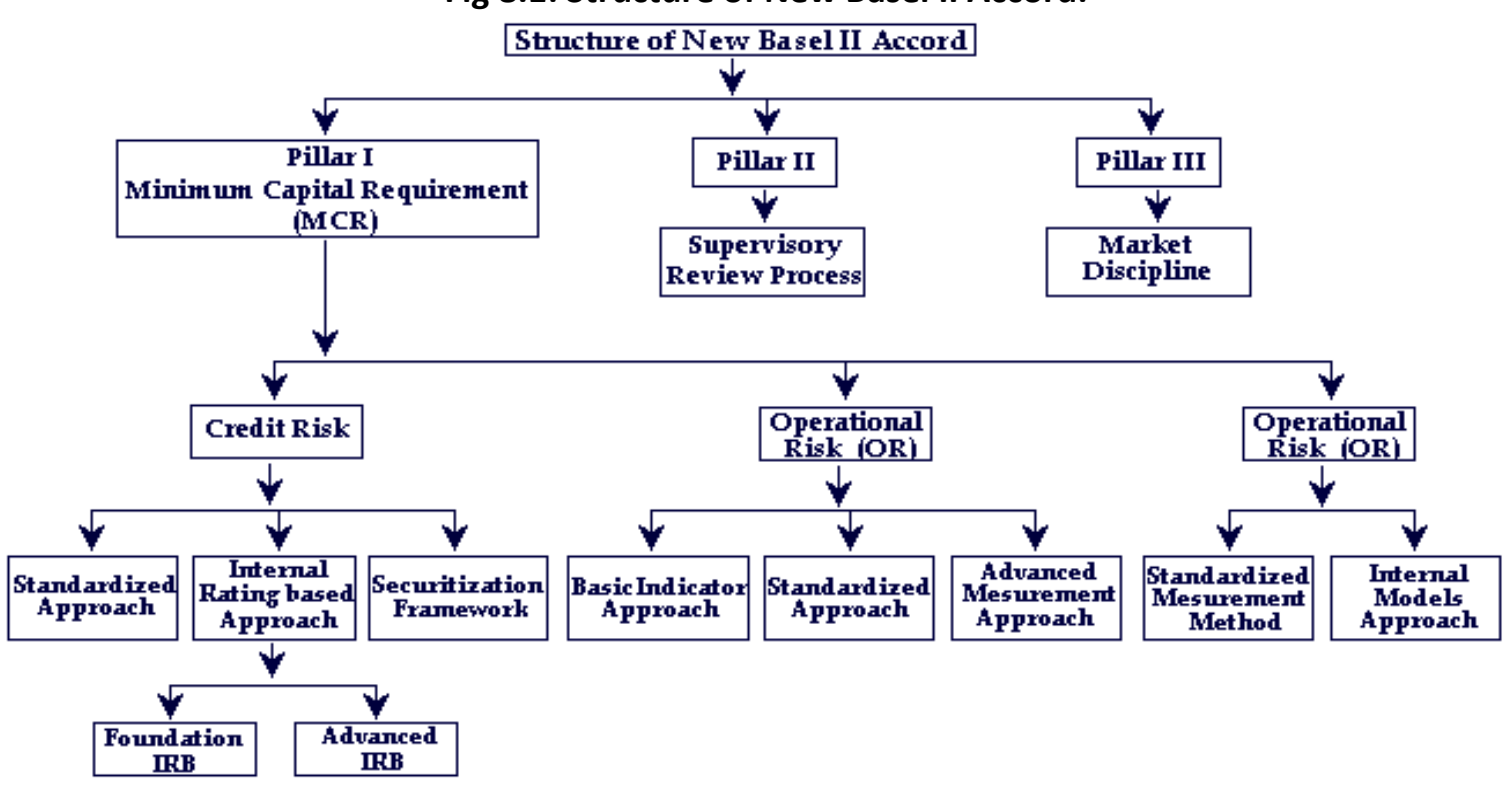

Basell II accord is based upon three pillars -

\section{- $\quad$ The First Pillar}

The first pillar deals with maintenance of regulatory capital calculated for three major components of risk that a bank faces: credit risk, operational risk and market risk. Other risks are not considered fully quantifiable at this stage.

The credit risk component can be calculated in three different ways of varying degree of sophistication, namely standardized approach, Foundation IRB and Advanced IRB. IRB stands for "Internal Rating-Based Approach". For operational risk, there are three different approaches - Basic Indicator Approach or BIA, Standardized Approach or TSA, and Advanced Measurement Approach or AMA. For market risk the preferred approach is VAR (Value at Risk)

- $\quad$ The Second Pillar

The second pillar deals with the regulatory response to the first pillar, giving regulators much improved 'tools' over those available to them under Basel I. It also provides a framework for dealing with all the other risks a bank may face, such as systemic risk, pension risk, concentration risk, strategic risk, reputation risk, liquidity risk and legal risk, which the accord combines under the title of residual risk. It gives bank a power to review their risk management system.

\section{- $\quad$ The Third Pillar}

The third pillar greatly increases the disclosures that the bank must make. This is designed to allow the market to have a better picture of the overall risk position of the bank and to allow the counterparties of the bank to price and deal appropriately. 
The Basel II Accord focuses on the following three areas :

- Minimum Capital Requirement :

The committee recognizes that to have a sound bank it is necessary to have a minimum volume of capital matching the risk profile of the Bank. The capital provides the bank with safety cushion to absorb losses without compromising on its obligations. The minimum ratio of regulatory capital with risk-weighted assets should not be less than $8 \%$.

The committee recognize that banks face three major kinds of risks :

- $\quad$ Credit Risk

- Operational Risk

- $\quad$ Market Risk (Trading Book Issues)

Total risk-weighted assets are determined by multiplying the capital requirements for market risk and operational risk by 12.50 and adding the resulting figures to the sum of riskweighted assets for credit risks.

- Supervisory Review :

The committee has laid out key principles of supervisory review, risk management guidance, supervisory transparency and accountability with respect to banking risks. It also includes guidance relating to treatment of interest rate risk in the banking book, credit risk, enhanced cross-border communication and cooperation and securitization.

- Public Discloser :

The committee stresses on public disclosure as a means to improve on the market discipline. The disclosure will be in the area of Capital Structure, Capital Adequacy, Risk Exposure and assessment in the areas of Credit Risk, Market Risk, Operational Risk, Interest Rate Risk, etc.

\subsection{BASEL II ACCORD \& CREDIT RISKS :}

The committee permits a bank a choice between two broad methodologies for calulating their capital requirements for Credit Risk.

One alternative will be to measure Credit Risk in a standardized manner as provided $b$ the committee, supported by external credit assessments.

The alternative methodology allows banks to use their internal rating systems for credit risk subject to the explicit approval of the supervisor bank.

\section{Principles for the Assessment of Banks' Management of Credit Risk :}


- Establishing an appropriate credit risk environment :

- Principle 1: The board of directors should have responsibility for approving and periodically reviewing the credit risk strategy and significant credit risk policies of the bank. The strategy should reflect the bank's tolerance for risk and the level of profitability the bank expects to achieve for incurring various credit risks.

- Principle 2: Senior management should have responsibility for implementing the credit risk strategy approved by the board of directors and for developing policies and procedures for identifying, measuring, monitoring and controlling credit risk. Such policies and procedures should address credit risk in all of the bank's activities and at both the individual credit and portfolio levels.

- Principle 3: Banks should identify and manage credit risk inherent in all products and activities. Banks should ensure that the risks of products and activities new to them are subject to adequate procedures and controls before being introduced or undertaken, and approved in advance by the board of directors or its appropriate committee.

- Operating under a sound credit granting process :

- Principle 4: Banks must operate under sound, well-defined credit-granting criteria. These criteria should include a thorough understanding of the borrower or counterparty, as well as the purpose and structure of the credit, and its source of repayment.

- Principle 5: Banks should establish overall credit limits at the level of individual borrowers and counterparties, and groups of connected counterparties that aggregate in a comparable and meaningful manner different types of exposures, both in the banking and trading book and on and off the balance sheet.

- Principle 6: Banks should have a clearly-established process in place for approving new credits as well as the extension of existing credits.

- Principle 7: All extensions of credit must be made on an arm's-length basis. In particular, credits to related companies and individuals must be monitored with particular care and other appropriate steps taken to control or mitigate the risks of connected lending.

- Maintaining an appropriate credit administration, measurement and monitoring process : 
- Principle 8: Banks should have in place a system for the ongoing administration of their various credit risk-bearing portfolios.

- Principle 9: Banks must have in place a system for monitoring the condition of individual credits, including determining the adequacy of provisions and reserves.

- Principle 10: Banks should develop and utilize internal risk rating systems in managing credit risk. The rating system should be consistent with the nature, size and complexity of a bank's activities.

- Principle 11: Banks must have information systems and analytical techniques that enable management to measure the credit risk inherent in all on- and off-balance sheet activities. The management information system should provide adequate information on the composition of the credit portfolio, including identification of any concentrations of risk.

- Principle 12: Banks must have in place a system for monitoring the overall composition and quality of the credit portfolio.

- Principle 13: Banks should take into consideration potential future changes in economic conditions when assessing individual credits and their credit portfolios, and should assess their credit risk exposures under stressful conditions.

\section{- Ensuring adequate controls over credit risk}

- Principle 14: Banks should establish a system of independent, ongoing credit review and the results of such reviews should be communicated directly to the board of directors and senior management.

- Principle 15: Banks must ensure that the credit-granting function is being properly managed and that credit exposures are within levels consistent with prudential standards and internal limits. Banks should establish and enforce internal controls and other practices to ensure that exceptions to policies, procedures and limits are reported in a timely manner to the appropriate level of management.

- Principle 16: Banks must have a system in place for managing problem credits and various other workout situations.

- $\quad$ The Role of Supervisors :

- Principle 17: Supervisors should require that banks have an effective system in place to identify, measure, monitor, and control credit risk as part of an overall approach to risk management. Supervisors should conduct an independent evaluation of a bank's strategies, policies, practices and procedures related to the granting of credit and the ongoing management of the portfolio. Supervisors should consider setting prudential limits to restrict bank exposures to single borrowers or groups of connected counterparties.

\subsection{IMPLEMENTATION OF BASEL II CAPITAL ACCORD}

Under the new risk based capital adequacy Basel II, JBL's capital management approach is driven by its desire to maintain a strong capital base to support the development of its business, to meet regulatory capital management at all times and to maintain good credit ratings. Strategic business 
and capital plans are drawn up annually covering a three year horizon and approved by the board. The plan ensures that adequate levels of capital and an optimum mix of the different components of capital are maintained by the bank to support the strategy. This is integrated with the bank's annual planning process that takes into account business growth across different products.

The bank is going to use a capital model to assess the capital demand for material risk, and to support its ICAAP (Internal Capital Adequacy Assessment Process). Each material risk will be assessed, relevant mitigates will be considered and appropriate level of capital will be determined.

JBL has formed "Basel-II Implementation Unit" and a "Risk Management Committee" in line with Bangladesh Bank's guideline and has been arranging meetings on monthly basis. JBL has also formed an exclusive body named "Basel-II Supervisory Review Committee" in line with pillar-II of Basel-II. To undertake the review process for capital adequacy to undertake the review process for capital adequacy in relation to its risk profile and to evaluate bank's internal capital adequacy assessment and strategy. 


\section{ANALYSIS \& FINDINGS}

\subsection{DEPOSITS \& DEPOSIT MIX:}

In commercial Banks operation starts with mobilization of resources i.e. collection of deposits and then the same are deployed as loans, advances and investment for the purpose of maximizing wealth. Thus, deposit is the lifeblood of a bank.

In keeping with this axiom JBL attaches utmost importance to the deposit mobilization campaign and to the optimal deposit mix for minimum cost of fund as much as possible.

The comparative position of Deposits \& Deposit Mix of the Bank for the last two years is depicted below:

Table 9.1: Comparison between Deposits \& Deposits mix of last two years (figure in BDT Million) 


\begin{tabular}{lccc}
\hline \multicolumn{1}{c}{ Type of Deposits } & As on & As on & $\begin{array}{c}\text { Changes } \\
+/(-)\end{array}$ \\
\hline Current A/c \& Other & 3283.21 & 2625.67 & $\mathbf{6 5 7 . 5 4}$ \\
\hline Bills Payable & 412.03 & 354.44 & $\mathbf{5 7 . 5 9}$ \\
\hline Savings Deposit & 1679.40 & 1407.32 & $\mathbf{2 7 2 . 0 8}$ \\
\hline Short Term Deposit & 1335.16 & 833.81 & $\mathbf{5 0 1 . 3 5}$ \\
\hline Fixed Deposit & 16360.18 & 13125.13 & $\mathbf{3 2 3 5 . 0 5}$ \\
\hline Scheme Deposits & 4131.80 & 2525.08 & $\mathbf{1 6 0 6 . 7 2}$ \\
\hline Foreign Currency Deposit & 106.16 & 52.57 & $\mathbf{5 3 . 5 9}$ \\
\hline TOTAL DEPOSITS & $\mathbf{2 7 3 0 7 . 9 4}$ & $\mathbf{2 0 9 2 4 . 0 2}$ & $\mathbf{6 3 8 3 . 9 2}$ \\
\hline
\end{tabular}

(Source: Annual report of Jamuna Bank Limited, 2013)

Under the prevailing extremely competitive market JBL has been able to instill confidence in customers as to its commitment to the depositors and borrowing customers and thereby could mobilize a total deposit of Tk.20924.02 million in 2012 against that of Tk.17284.81 million showing an increase of Tk.3639.21 million (21.05 percent). 


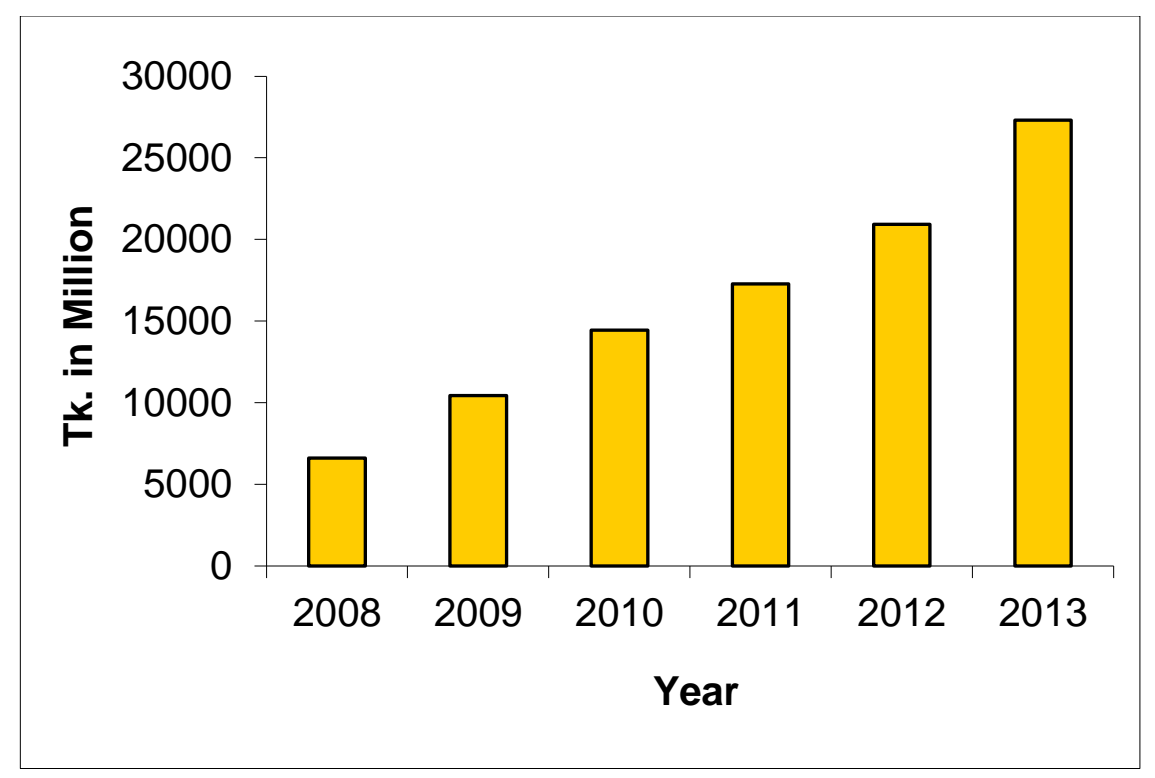

Figure 9.1.2: The Deposit Mix of JBL as on 31st December, 2013

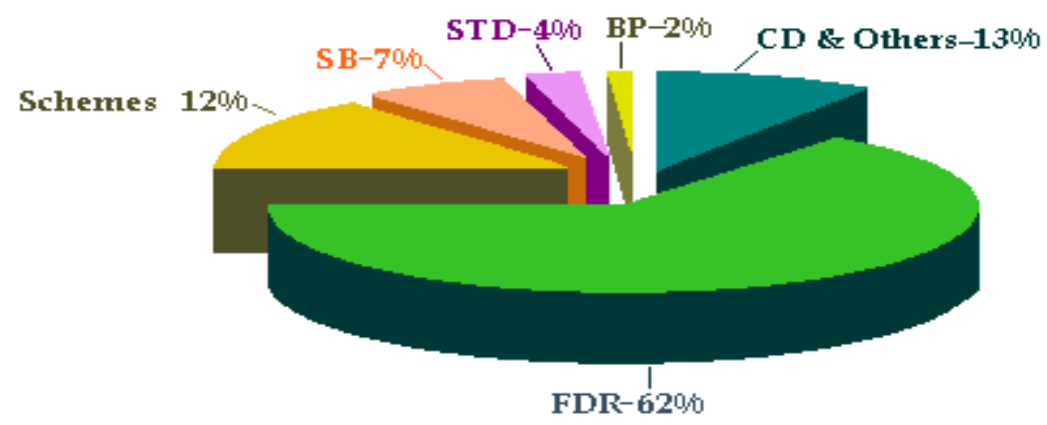

As per Deposit mix of JBL out of its total deposits $74 \%$ of (FDR-62\% \& Deposits under different Schemes$12 \%)$ were high cost deposits, $11 \%$ were low cost deposits (SB-7\% \& STD-4\%) and $15 \%$ were no cost deposits (CD \& Others $-13 \%$ \& $B P-2 \%)$. So, it is observed that the bulk of deposits i.e. three fourth of total deposits were of high cost. Meanwhile, for healthy growth of business JBL puts emphasis on no cost and low cost deposit and endeavor thereof is underway for augmenting low cost deposit by accommodating good customers at competitive price.

\subsection{COST OF FUNDS (DEPOSIT COST \& OVERHEAD COST) :}

The Cost of Funds of JBL in 2013 was 12.26\%, which was 12.18\% in 2012. So, it is noted that in 2013 the cost of funds was bit higher than that of 2012. 


\section{Figure 9.2: Year wise Cost of Funds of JBL over the last 06(six) years}

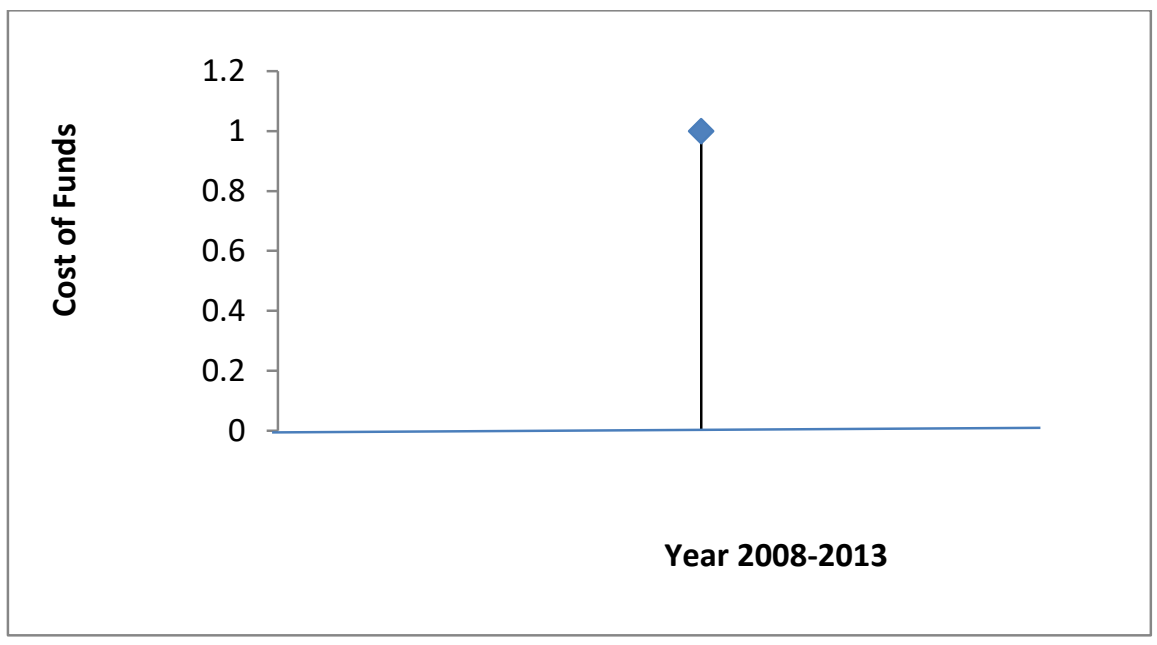

(Source: Balance Sheet of Jamuna Bank Limited, 2013)

\subsection{LOANS \& ADVANCES:}

Under the unfavorable business environment due to political turmoil throughout the year JBL was in constant efforts to explore different areas of credit operation and could raise the loans and advances portfolios to Tk.16617.15 million in 2013 with an increase of Tk.3820.82 million (29.86\%) over that of the preceding year.

Figure9.3: Year wise Loans \& Advances of JBL over the last 05(five) years

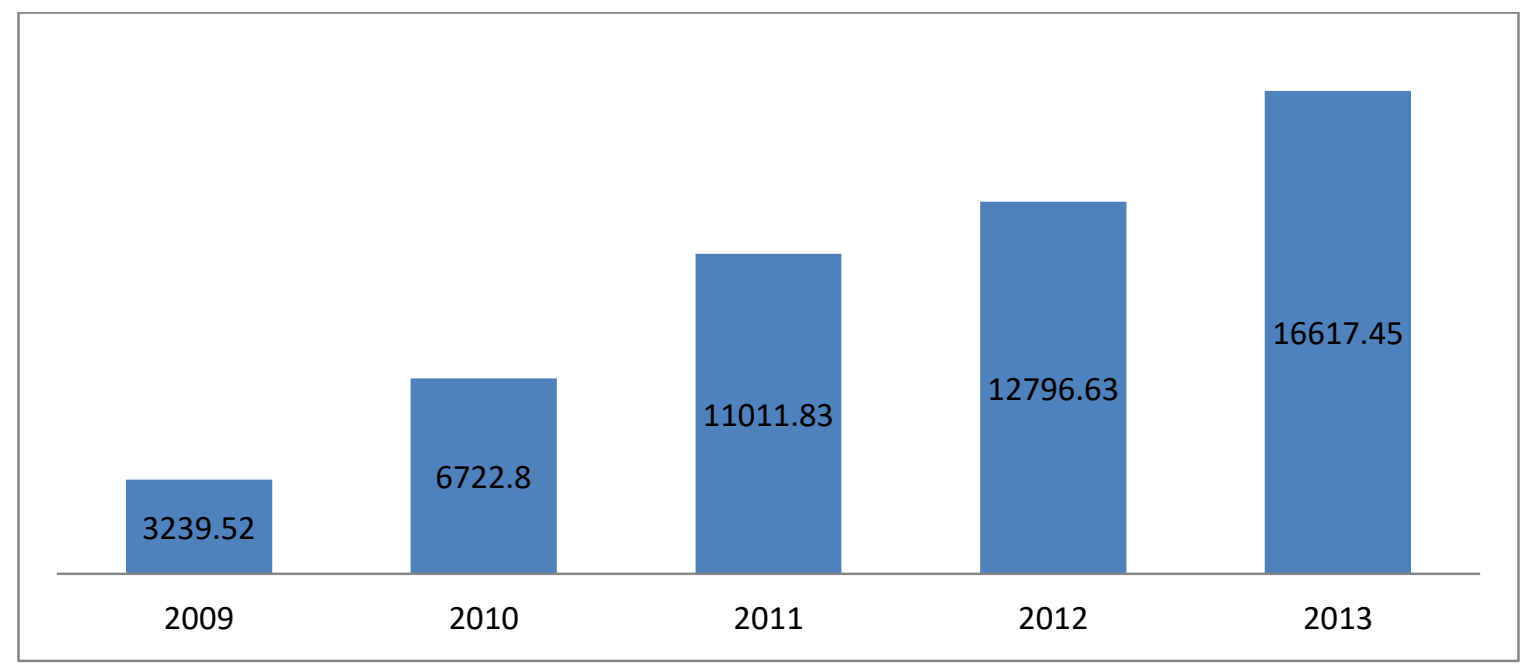

\subsection{CLASSIFIED LOANS \& ADVANCES:}

Over the last couple of years the Ratio of Classified Loans \& Advances out of Total Loans \& Advances has been increased alarmingly with respect to than that of the previous years. This is due to tremendous growth of loan portfolio within a short span of time. 
However, percentage of non-performing loan has decreased significantly as a result of efficient credit risk management. (Figure 9.4)

Figure 9.4: Percentage of Non-performing Loans of JBL

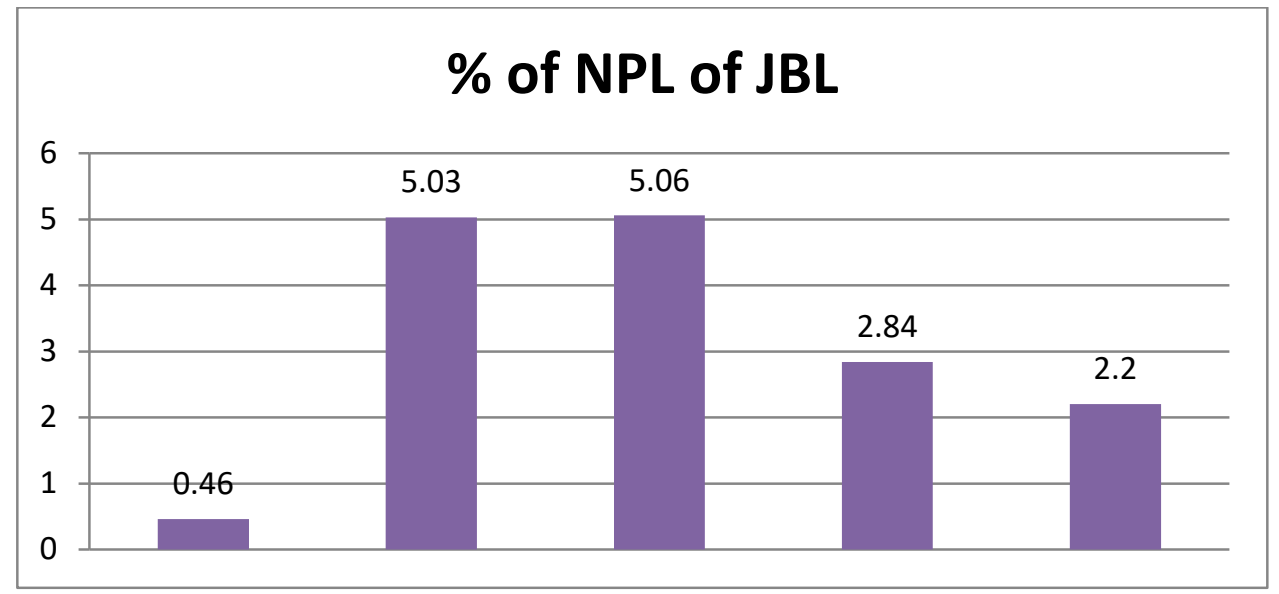

(Source: Annual report of Jamuna Bank Limited, 2013)

\subsection{INVESTMENT:}

JBL's investment portfolio as on 31/12/2012 rose to Tk.5390.03 million from Tk.2552.67 million as on $31 / 12 / 2013$ registering an increase of Tk.2837.36 million (111.15\%).

Figure 9.5.1: Year wise Investment position of JBL over the last 05(five) years

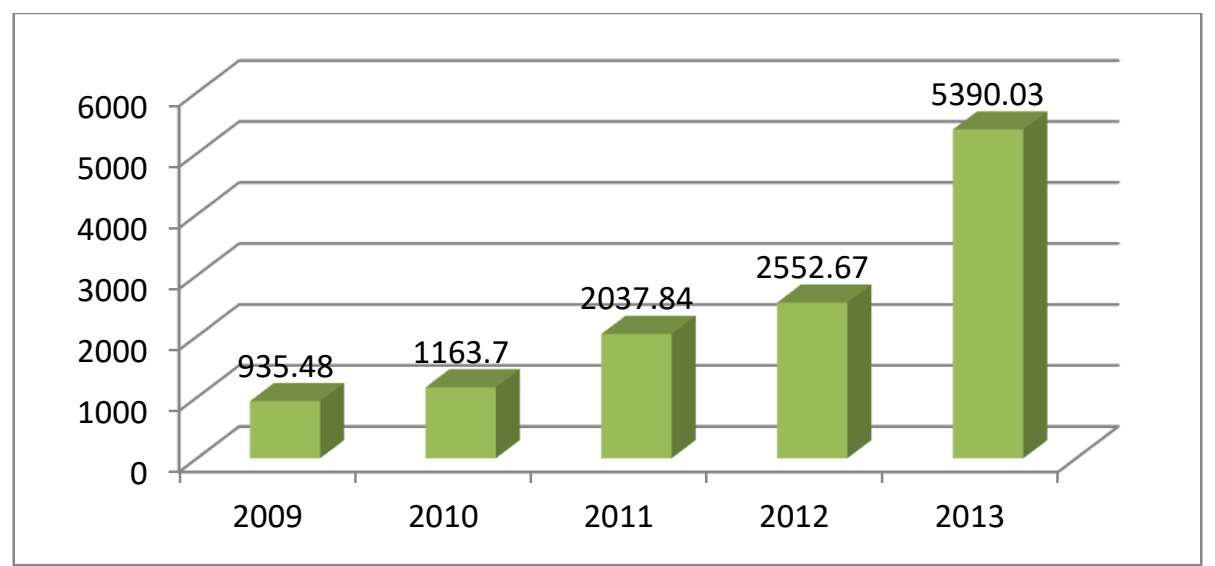

The investment portfolio was blended with Govt. Treasury Bills of Tk.2410.51 million, Treasury Bonds of Tk.2935.54 million, investment in Primary Shares and Zero Coupon Bonds of Tk.43.61 million. Its investment was made in acquisition of Preference Shares of Tk.2.50 (5.00-2.50) million of Aftab 
Automobiles Ltd. Besides, Tk.2.00 million has been invested in acquisition of two shares of Central Depository Bangladesh Ltd. (CDBL). The Bank's major portion of investment in Govt. Treasury Bills and Bonds is for the purpose of fulfilling Statutory Liquidity Requirement (SLR).

Figure 9.5.2: Investment Mix

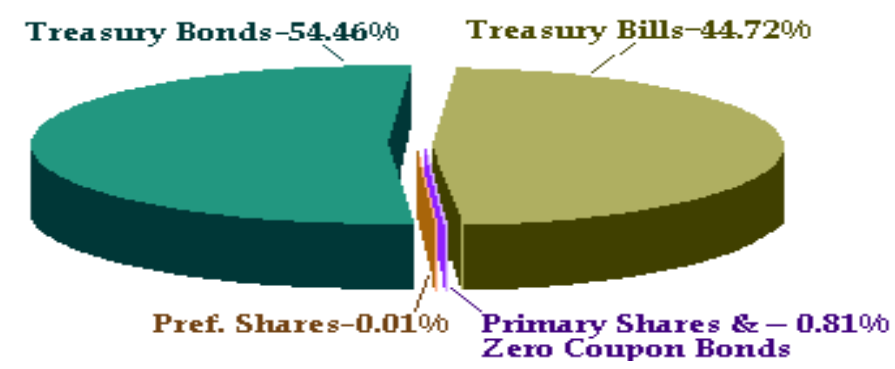

9.6 YEAR WISE COMPARATIVE POSITION AMONG DEPOSITS, LOANS \& ADVANCES AND INVESTMENTS DURING THE LAST 05(FIVE) YEARS

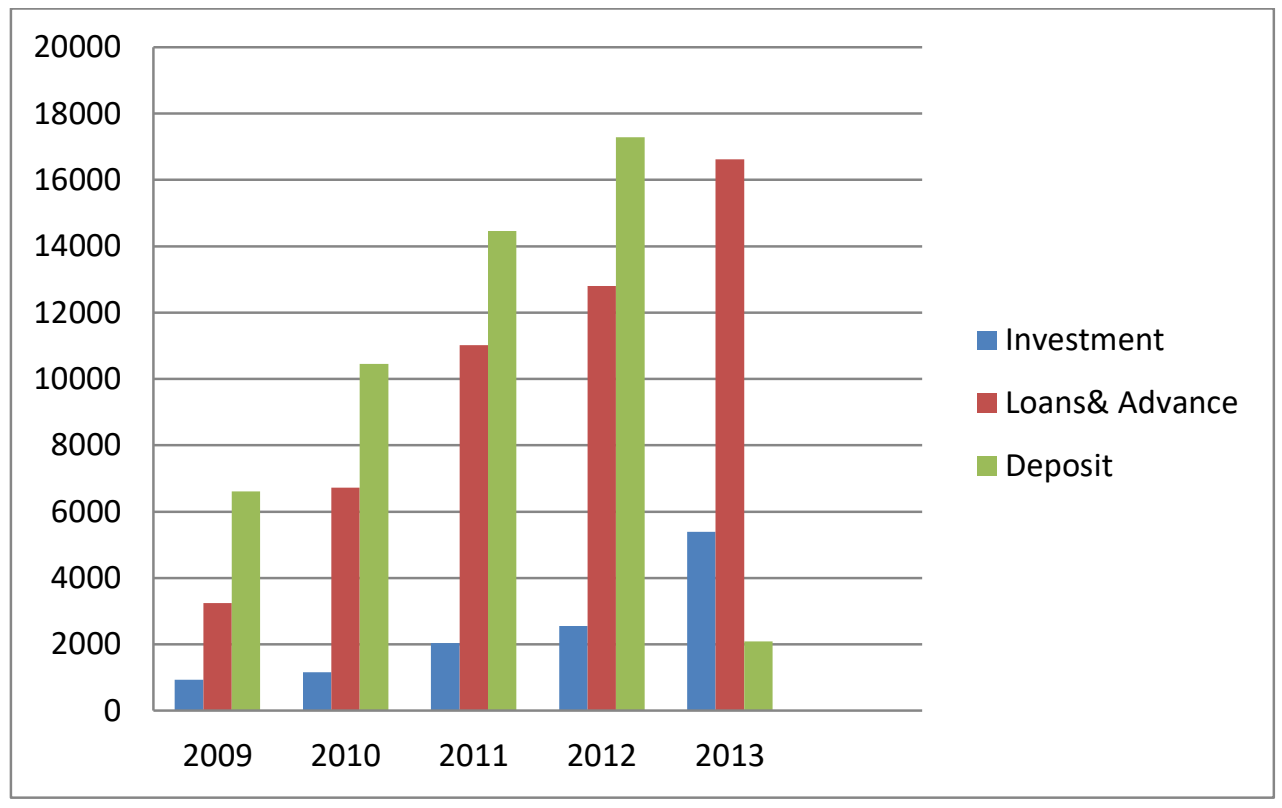

Figure 9.6: Comparison among Deposits, Loans \& Advances

From the above we can see that compare to 2009 and 2010, company go on a larger scale of risk by investment. Also the deposit collection is great till 2012, but at 2013, it's become downward. JBL also take a huge challenge by providing large number of loans and advancement since 2009 till now.

\subsection{ADVANCE DEPOSIT RATIO :}


The Advance Deposit Ratio of the Bank in 2013 was 79.42\%, while the said Ratio was $74.03 \%$ in 2012 . So, it is noted that the Bank employed its more portion of Deposits in 2013 in comparison with 2012.

Figure 9.7: Year wise Advance Deposit Ratio of JBL during the last 05(five) years :

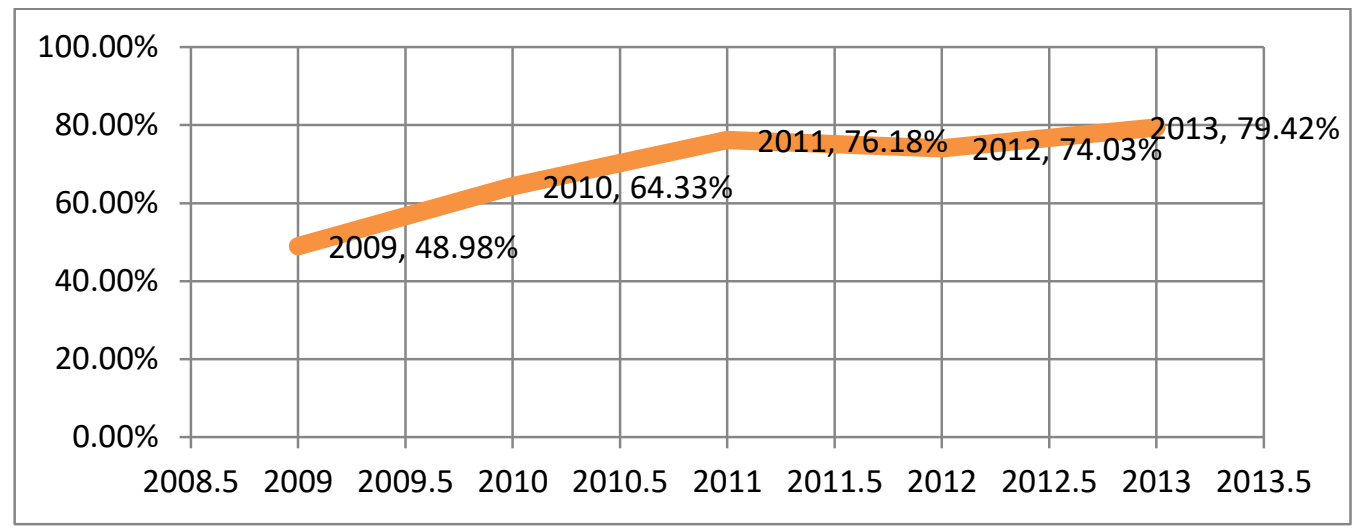

\subsection{IMPORT BUSINESS:}

The total import business handled by the Bank in 2013 was Tk.22191.84 million compared to Tk.15457.66 million in the preceding year registering a rise of Tk.6734.18 million (43.57 percent).

The import items included industrial raw materials, machinery, consumer goods, fabrics, accessories, etc.

\section{Figure 9.8: Year wise Import Business done by JBL during the last 05(five)}

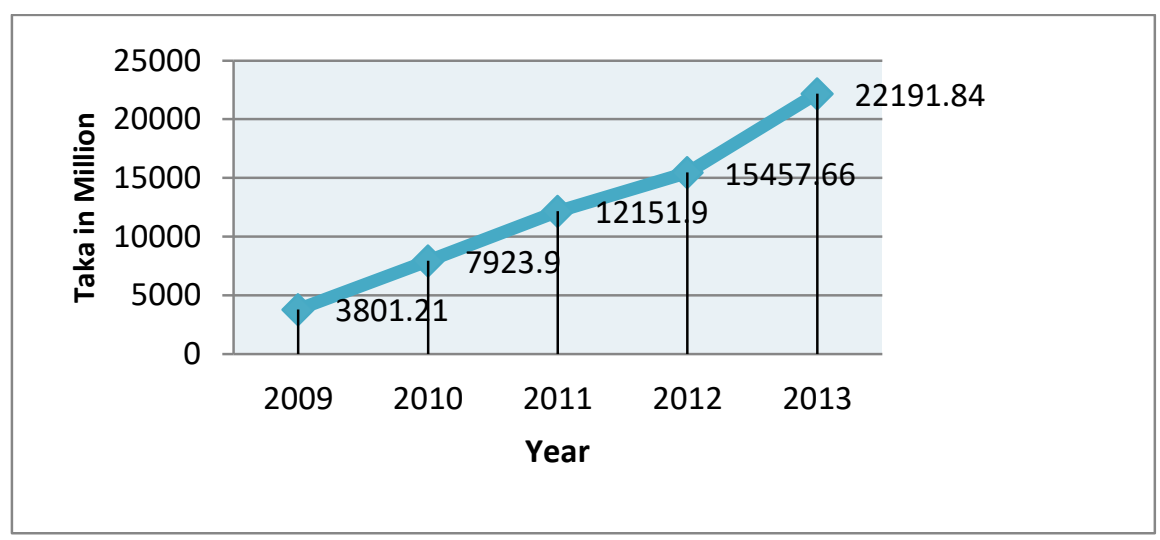

\subsection{EXPORT BUSINESS:}

The Bank handled total export business worth Tk.13990.33 million in 2013. In 2012 export business handled by the Bank was Tk.11583.64 million. Thus, there was an increase of Tk.2406.69 million in export 
business handled by the Bank (20.78 percent over the preceding year). The major export item was Readymade Garments.

Figure 9.9: Year wise Export Business done by JBL during the last 05(five) yeas :

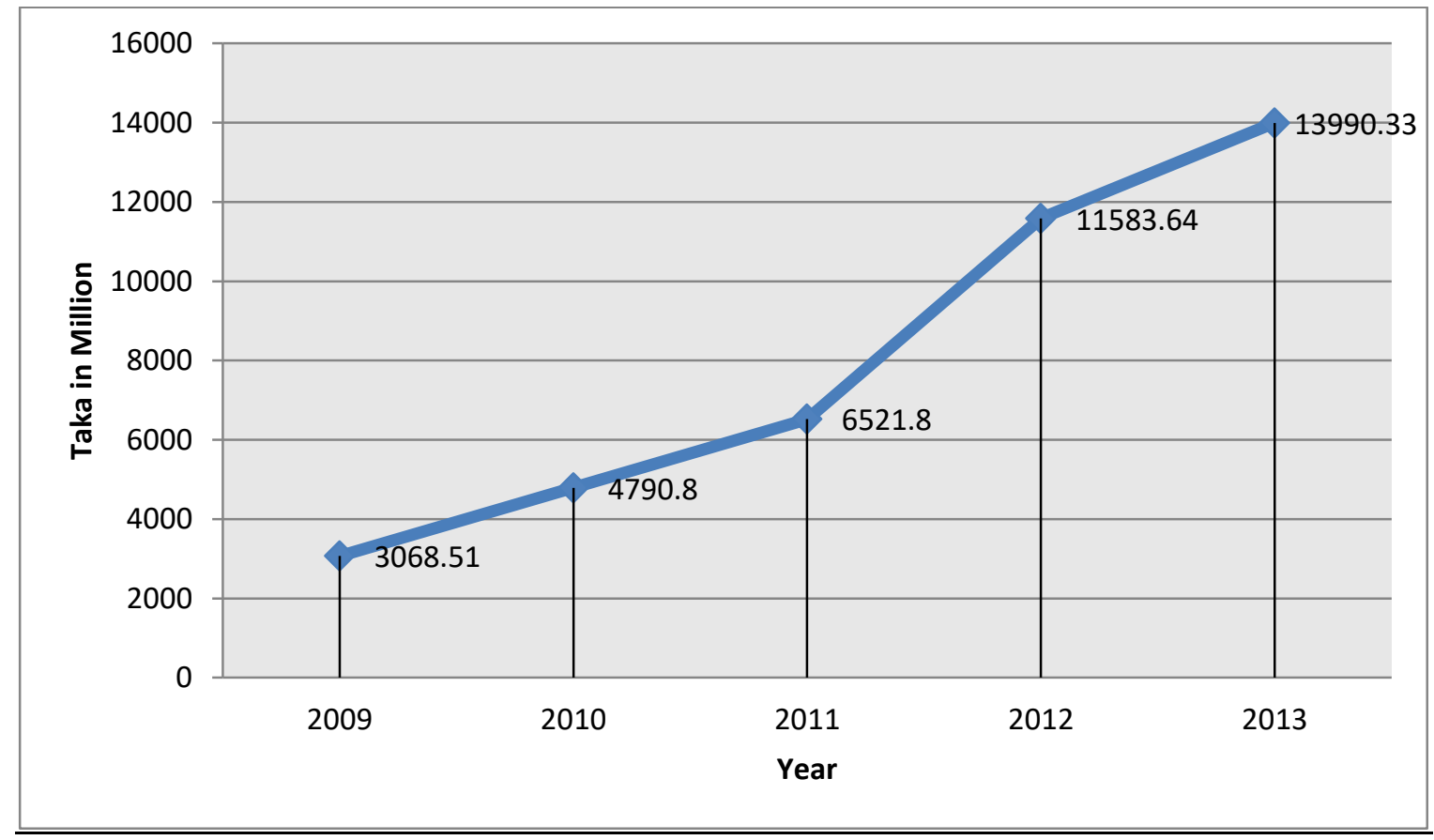

\subsection{TOTAL INCOME \& EXPENDITURE:}

The Bank generated total income of Tk.3102.99 million in 2013 compared to Tk.2749.90 million in the preceding year registering a rise of Tk.353.09 million (12.84 percent).

On the other hand, total expenditure incurred Tk.2278.79 million in 2013 and Tk.2048.58 million in 2012 that means expenditure increased by Tk.230.21 million (11.24 percent). 
Figure 9.10: Year wise Income \& Expenditure of JBL during the last 05(five) years:

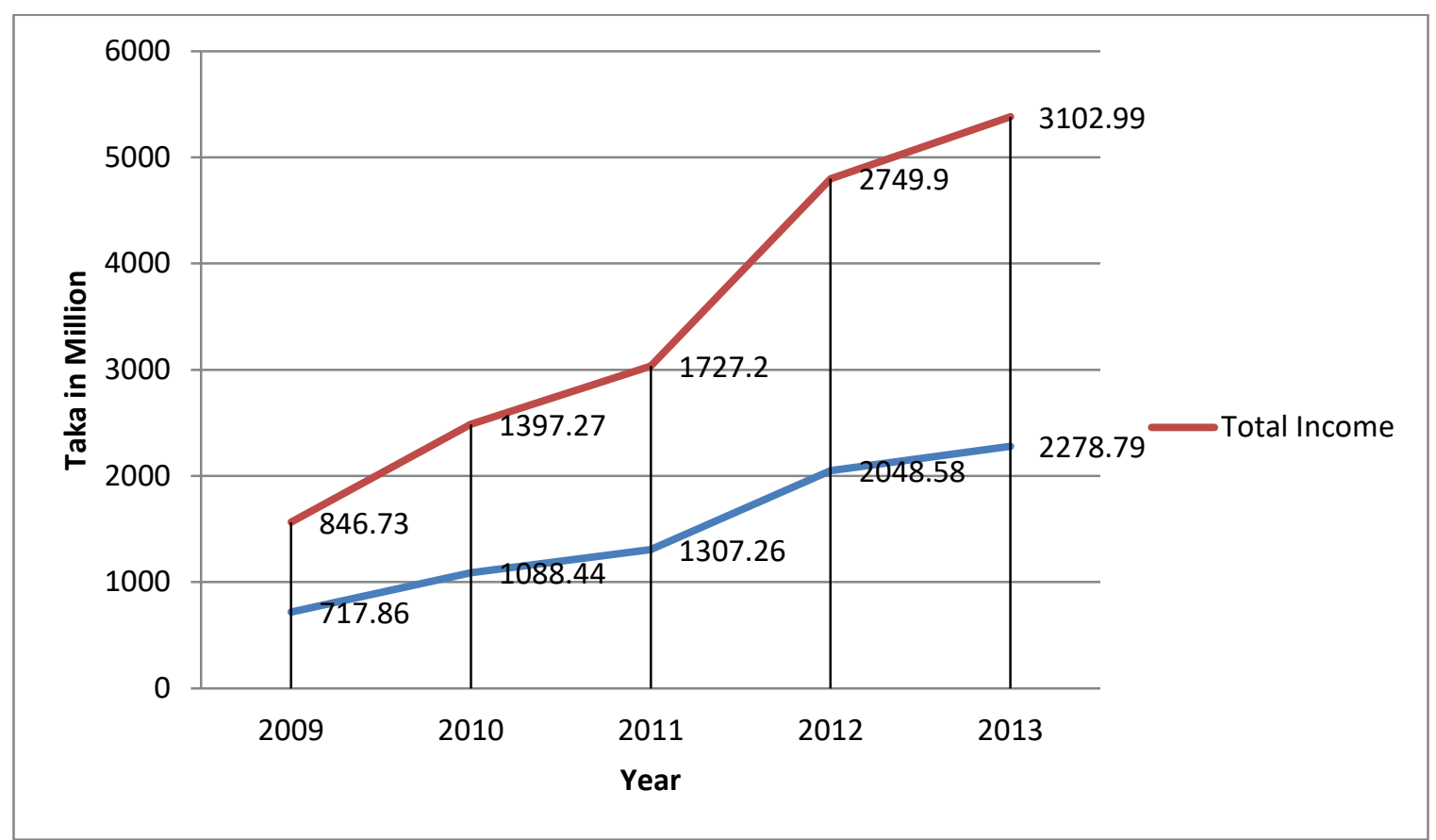

\subsection{PROFIT:}

JBL made Operating Profit of Tk.824.20 million in 2013 compared to Tk.701.32 million in the preceding year registering a rise of Tk.122.88 million (17.52 percent).

On the other hand, Profit Before Tax was Tk.405.04 million in 2013 and Tk.499.97 million in 2012 that means it declined by Tk.94.93 million (18.99 percent).

While Profit After Tax was Tk.89.11 million in 2013 and Tk.253.40 million in 2012 that means After Tax Profit was seriously dropped by Tk.164.29 million being 63.83 percent. 
Figure 9.11: Year wise Profit of JBL over the last 05(five) years

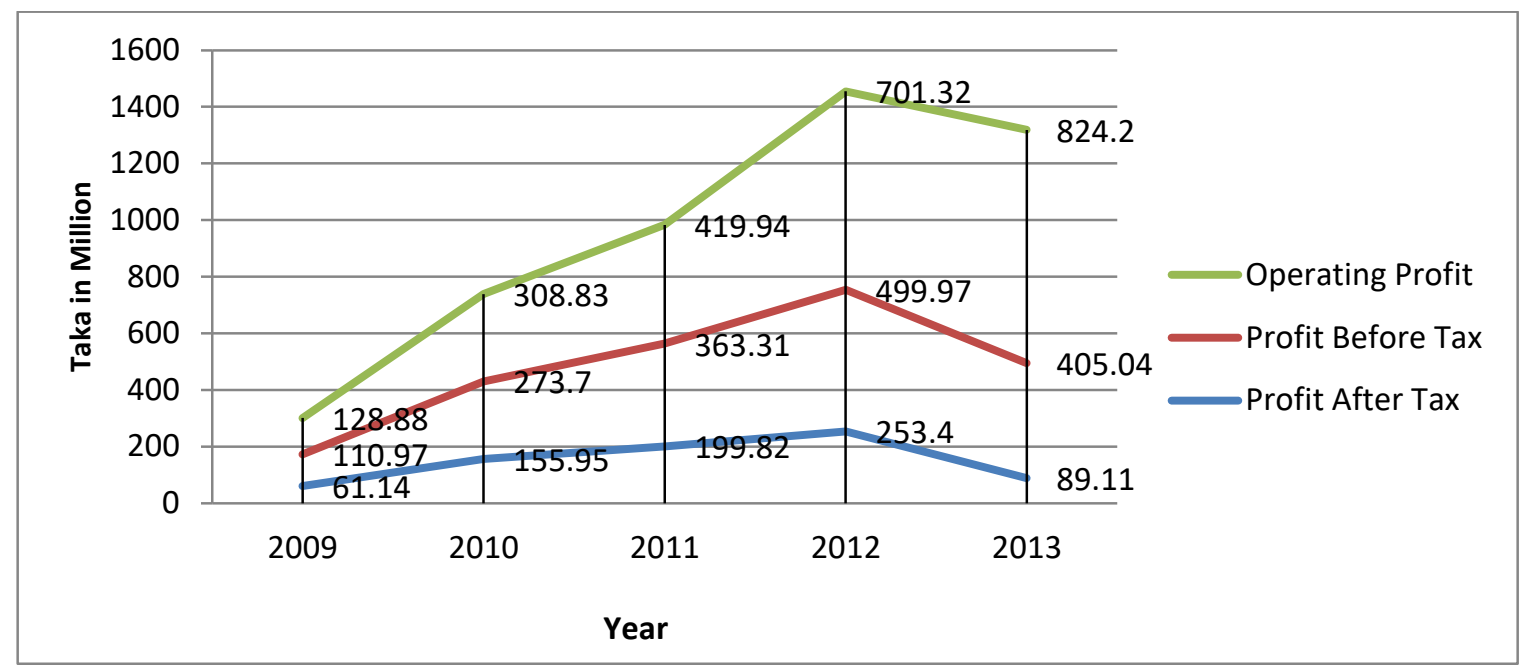

\subsection{CAPITAL STRUCTURE}

JBL raised its Authorized Capital at Tk.4000.00 million in 2013 from Tk.1600.00 million.

On the other hand, Paid-up Capital of the Bank stood at Tk.1225.71 million as on 31/12/2013 compared to Tk.1072.50 million as on 31/12/2012 registering a rise of Tk.153.21 million (14.29 percent).

Figure 9.12: Year wise Capital Structure of JBL over the last 05(five) yeas as follows:

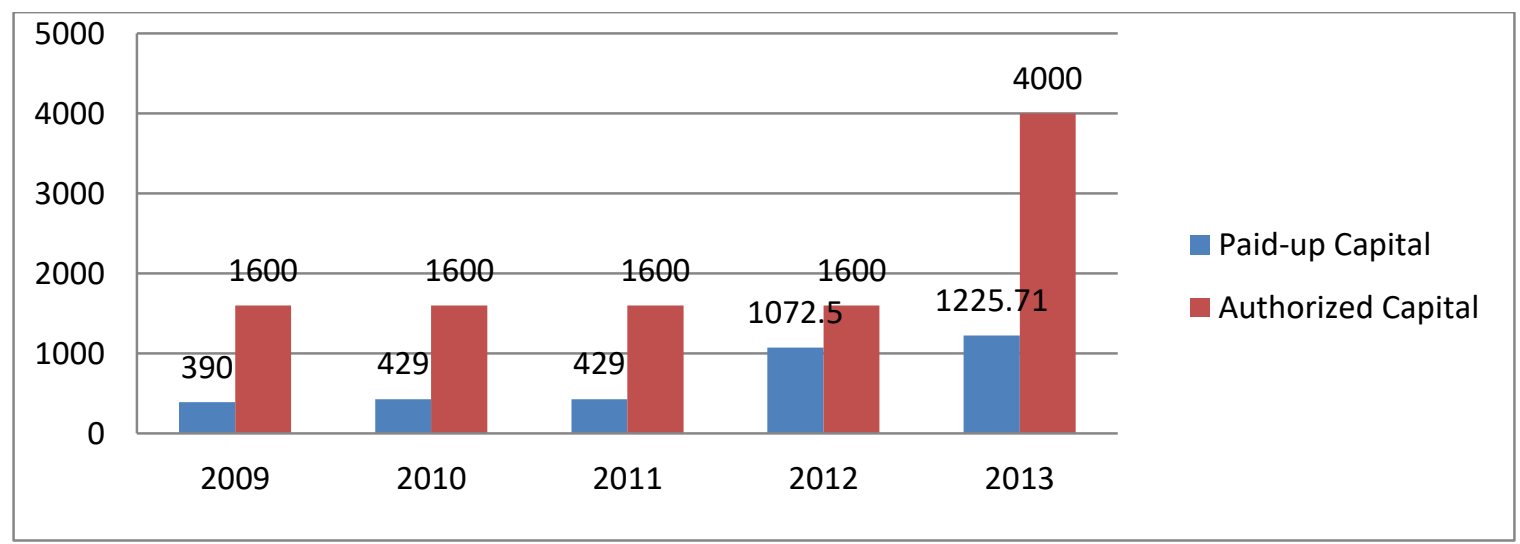




\subsection{CAPITAL, EQUITY \& LIABILITY POSITION:}

Figure 9.13: Year wise Capital, Equity \& Liability Position of JBL over the last 05(five) yeas were as follows

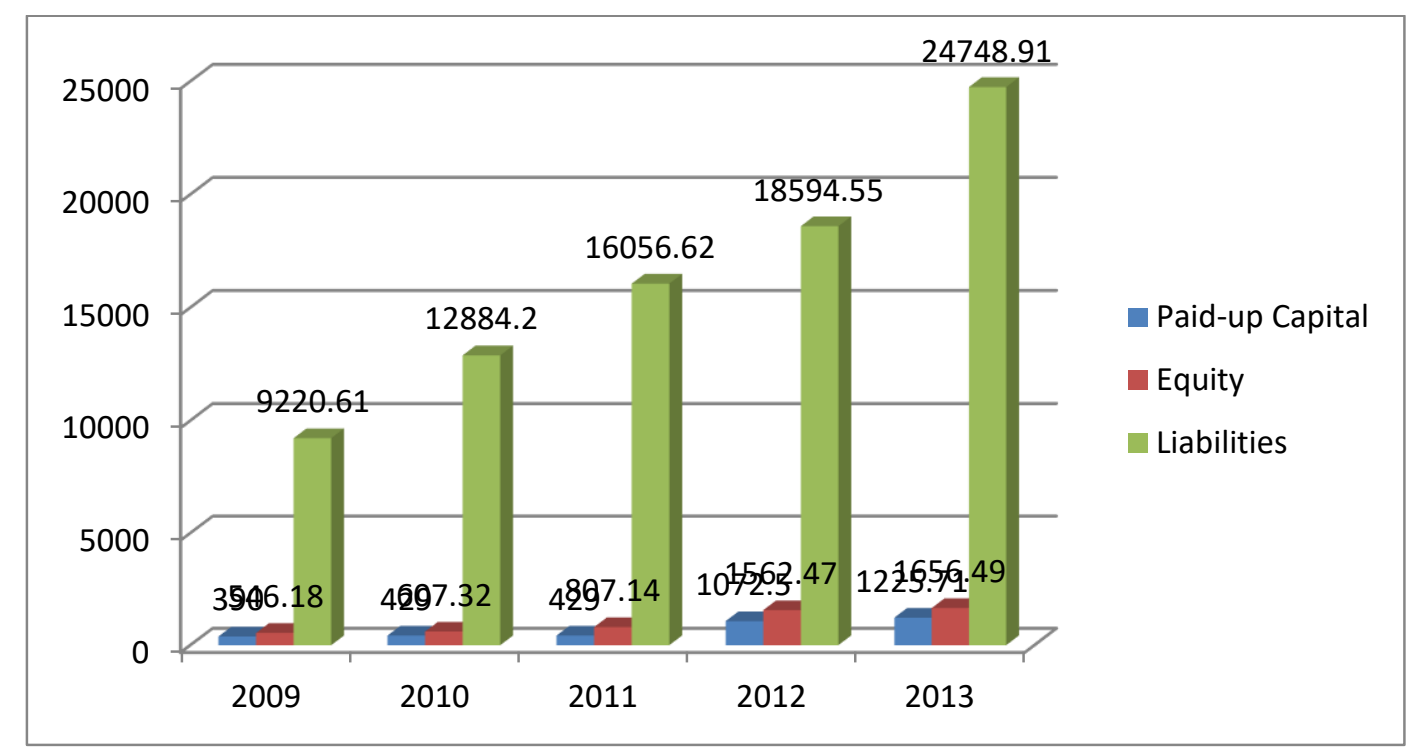

\subsection{PROFIT \& LOSS A/C FOR THE YEAR ENDED 2009 \& 2013:}

Figure in Million Taka

\begin{tabular}{|c|c|c|c|}
\hline Particulars & $\begin{array}{l}\text { Year- } \\
2013\end{array}$ & $\begin{array}{l}\text { Year- } \\
2012\end{array}$ & $\begin{array}{l}\text { Year- } \\
2011\end{array}$ \\
\hline Interest income \& Profit on investment & 2890.65 & 2230.27 & 2095.51 \\
\hline Less : Interest paid on Deposits and Borrowings, etc. & 2321.89 & (1774.39) & $(1606.88)$ \\
\hline Net Interest Income & 568.77 & 455.88 & 488.63 \\
\hline Investment Income & 666.15 & 474.48 & 255.66 \\
\hline Commission, Exchange and Brokerage & 419.95 & 320.72 & 328.77 \\
\hline
\end{tabular}




\begin{tabular}{|c|c|c|c|}
\hline Other Operating Income & 97.63 & 77.52 & 69.96 \\
\hline Total Operating Income (A) & 1752.50 & 1328.60 & 1143.02 \\
\hline \multicolumn{4}{|l|}{ Less : Operating Expenditure : } \\
\hline Salary and Allowances & 405.19 & 232.63 & 188.80 \\
\hline Rent, Taxes, Insurance, Electricity, etc. & 73.98 & 62.91 & 47.75 \\
\hline Legal Expenses & 1.72 & 1.54 & 3.05 \\
\hline Postage, Stamps, Telecommunication, etc. & 28.11 & 28.71 & 25.75 \\
\hline Stationery, Printing, Advertisement, etc. & 22.13 & 26.07 & 35.74 \\
\hline Director's fees \& other expenses & 6.12 & 4.16 & 2.72 \\
\hline Auditor's fees & 0.10 & 0.10 & 0.53 \\
\hline Managing Director's Salary \& Allowances & 7.13 & 6.27 & 2.81 \\
\hline $\begin{array}{l}\text { Depreciation, Repairs and Maintenance of Bank's } \\
\text { Assets }\end{array}$ & 36.67 & 30.25 & 27.21 \\
\hline Other Expenses & 131.14 & 111.76 & 107.35 \\
\hline Total Operating Expenses (B) & 712.30 & 504.40 & 441.71 \\
\hline PROFIT/ (LOSS) BEFORE PROVISIONS (C=A-B) & 1040.20 & 824.20 & 701.31 \\
\hline $\begin{array}{l}\text { Provision for Loans, Advances (including Off Balance } \\
\text { Sheet Exposure) }\end{array}$ & 174.39 & 419.16 & 201.15 \\
\hline Provision for other assets & ---- & --- & 0.19 \\
\hline Total Provision (D) & 174.39 & 419.16 & 201.34 \\
\hline TOTAL PROFIT BEFORE TAXES (C-D) & 865.82 & 405.04 & 499.97 \\
\hline
\end{tabular}




\begin{tabular}{|c|c|c|c|}
\hline Current Tax & 382.05 & 311.75 & 246.57 \\
\hline Deferred Tax & 2.45 & 4.18 & --- \\
\hline Provision for Taxation for the year & 382.05 & 315.93 & 246.57 \\
\hline NET PROFIT AFTER TAXATION & 479.44 & 89.11 & 253.40 \\
\hline Retained Surplus brought forward from Previous Year & 7.64 & 1.29 & 1.10 \\
\hline RETAINED SURPLUS BEFORE APPROPRIATION & 487.08 & 90.40 & 254.50 \\
\hline Statutory Reserve ( $20 \%$ on Pre-Tax Profit) & 173.16 & 81.00 & 99.99 \\
\hline Proposed Dividend as Bonus Share & --- & --- & --- \\
\hline Appropriations & 173.16 & 81.00 & 99.99 \\
\hline RETAINED SURPLUS & 38.21 & 9.40 & 154.51 \\
\hline Earnings Per Share (EPS) & 38.21 & 8.04 & 31.94 \\
\hline
\end{tabular}

(Source: Annual Report \& Balance Sheet of Jamuna Bank Limited, 2013) 


\title{
9.15 RETURN ON ASSETS:
}

\author{
We know, Return on Assets $=\underline{\text { Net Profit After Tax }}$ \\ Total Assets
}

Figure 9.15: Year wise Return on Assets of JBL during the last 05(five) yeas follows :

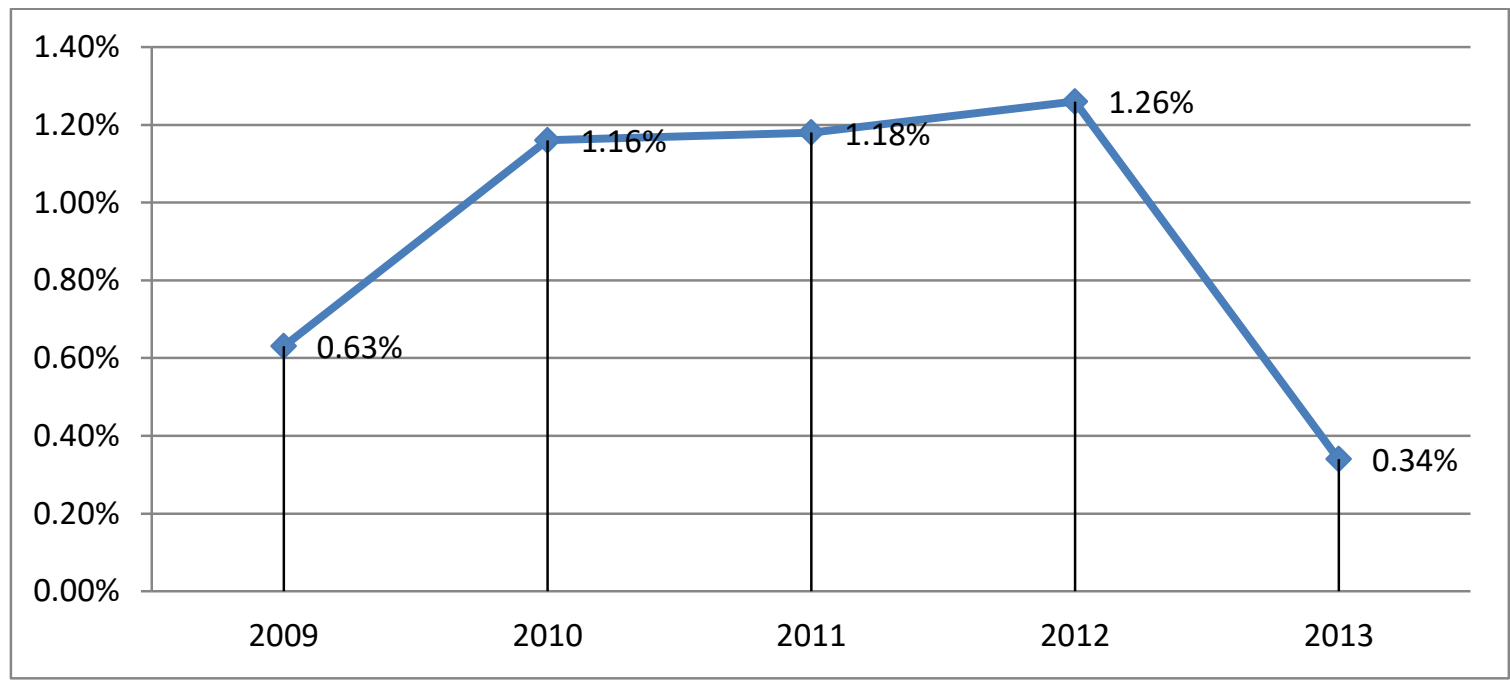

As return on asset is calculated by net profit after tax divided by total asset. Here we can see that the ROA is $0.63 \%$ at year 2009. And its keep going up till 2012 which was $1.26 \%$. But at 2013 , the mergin is fall $0.34 \%$.

\subsection{RETURN ON EQUITY:}

\section{We know, Return on Equity $=\underline{\text { Net Profit After Tax }}$ Shareholders' Equity}

Consequent upon the collapse in Return in equity of the Bank, the ROE tumbled down to $21.39 \%$ in 2012 compared to Tk.26 in the preceding year being a drop of 19 percent. The figure is given below: 
Figure 9.16: Year wise Return on Equity (ROE) of JBL during the last 05(five) years :

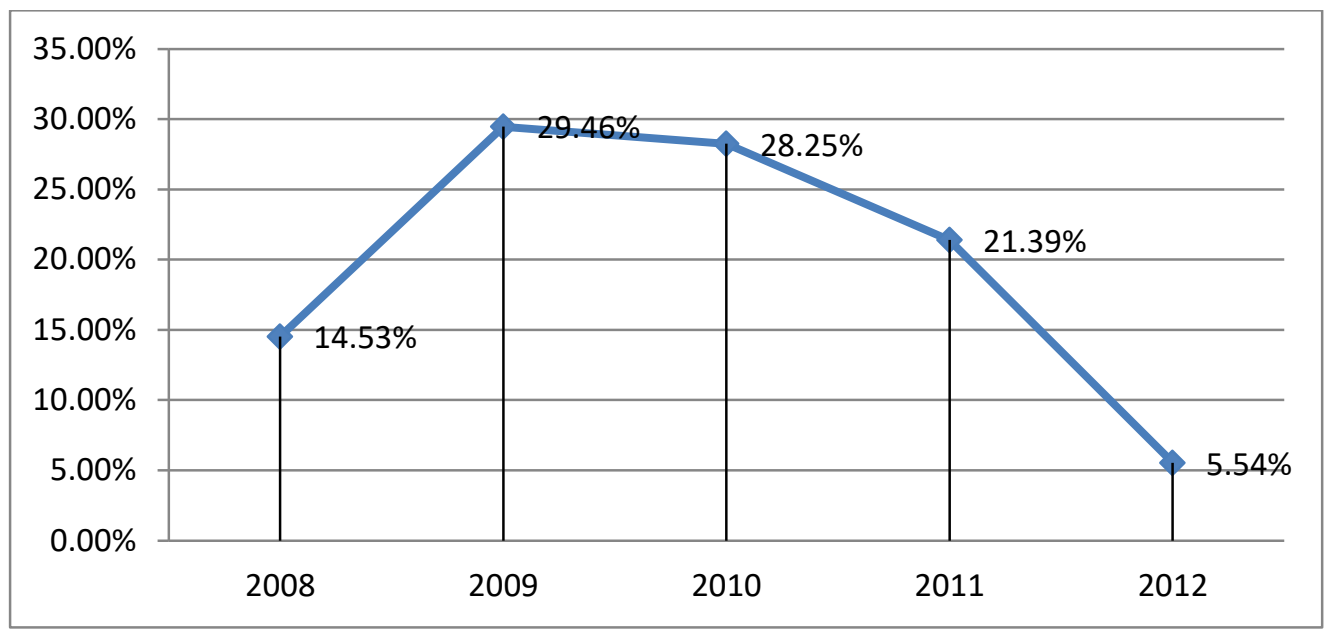

\subsection{EARNING PER SHARE (EPS) :}

Consequent upon the collapse in Profit After Tax of the Bank, the Earning Per Share (EPS) there from tumbled down to 8.04 in 2012 compared to Tk.31.94 in the preceding year being a drop of 74.83 percent.

Figure 9.17: Year wise Earning Per Share (EPS) of JBL over the last 05(five) years :

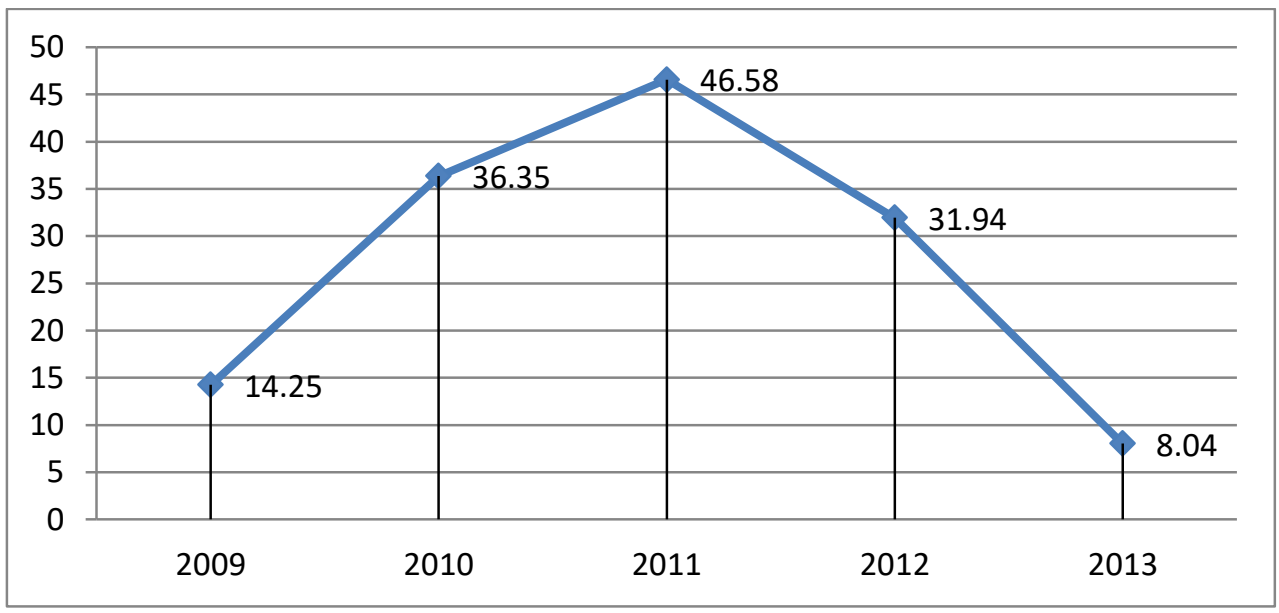




\subsection{NET ASSETS PER SHARE (NAV) :}

The Net Assets per Share Taka (NAV) of the Bank Tk.188.14 in 2012 compared to Tk.145.68 in the preceding year being a slight drop of 7.24 percent.

Figure 9.18: Year wise Net Assets Per Share (NAV) of JBL over the last 05(five) years :

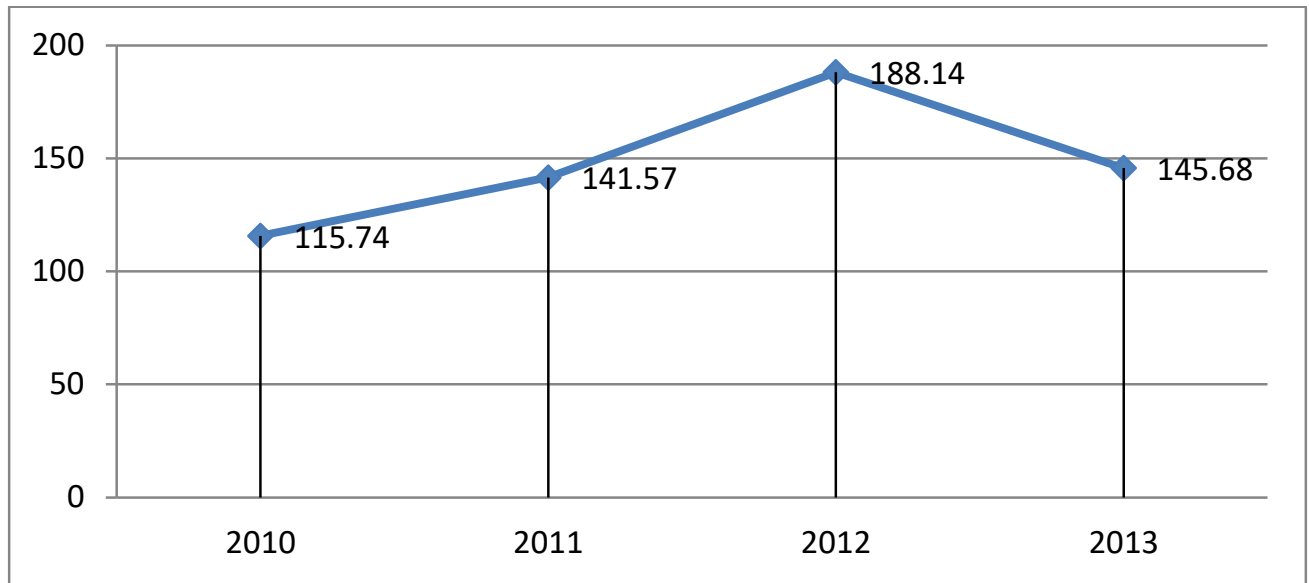




$$
\begin{gathered}
\text { CHAPTER } 10 \\
\text { RECOMMENDATION \& } \\
\text { CONCLUSION }
\end{gathered}
$$




\subsection{RECOMMENDATION}

As we all know JBL is one of the well known banks in our country. From my little knowledge it's quite hard to give recommendation to such a well established bank. Still from my learning and observation, I am giving following recommendation to follow:

- JBL need to more concentrate on loan and advance services. And they need to offer attractive packages to promote their loan and advance product.

- Maximum amount of loan is provided to the long-term industrial sectors. They intentionally ignore the agriculture sector because of riskiness and safety issues. But for the overall economic development of the country they should diversify their loans in agriculture sector.

- JBL has only 62 branches all over the country. Since day by day their demand is increasing so it is quite hard to provide full range services with those branches. So they need to put more attention toward the expansion of branch network as well as ATM Booths.

- For improving the recovery position and reducing huge over due loans, first action needed to attract political support and urge upon the govt. and political parties to take necessary steps for repayment of defaulted loans within a limit.

- New credit culture needs to be developed in place of default culture. Efforts to be taken as soon as possible to safeguard the interest of banking sector.

- Real value of business can come from making regular visits to the customer's place of business rather than holding all meetings in the Bank.

- JBL earns $68.87 \%$ profit from Dhaka City. So JBL need to spread their all over the Bangladesh.

\subsection{SUGGESTED NEW LOAN PRODUCTS FOR JBL}

\subsubsection{Women Entrepreneur Loan Scheme- "Sawnirbhor Naari"}

Now-a-days Jamuna Bank is offering different types of credit to the different groups like traders, industrialist, businessman, and individuals in case of personal loan. These are generally for all people but we are not providing something special for women. As Bangladesh bank has declared that for every five branches in metropolitan area one branch must be opened in rural area. We can utilize this opportunity. In rural area women are involved with many productive works like poultry, handicrafts etc in small extent. They can't able to get that job to the large extent for the shortage of capital. In urban and sub urban area there are also so many potential women entrepreneurs who are sitting idle only because they don't have enough capital to run their business. If we finance them at low rate under our SME project then it will be a great help for the growth of our economy. We can easily do that as BB offers confessional rate under the SME project to the disbursing bank in case of woman borrower. We can name the product as 'Sawnirbhor Naari'. 


\subsubsection{Ship Building Loan (Industrial loan)}

Ship building industry in Bangladesh is set to emerge as new export leader. Since major ship manufacturing countries like South Korea, Vietnam, China and Singapore are becoming less interested in building Small Ocean going vessels. European buyers are now coming to Bangladesh and India. The industry is gradually shifting towards developing countries like us mainly because of the availability of a cheap labor force. The global market for small ships is now about $\$ 400$ billion. If we can grab one per cent of the global order for small ships, the amount will be worth $\$ 4.0$ billion. Recently Bangladesh government has declared Ship Building Industry as 7th thrust sector. This is a very lucrative sector and will improve day by day. But this is a highly capital intensive industry. So there is a huge demand for Bank loan there. If we invest in this infant sector with lower interest rate then it would be a great help for this sector as well as our economy, which will flourish our image throughout the country. We can launch a new loan product especially for the Ship Building Industry named "Ship Building Loan".

\subsubsection{Syndication loan}

JBL's present position in syndication loan is not so pleasing. We should go for such kind of loan in near future frequently as it is a profitable sector to reap the maximum benefit for our bank. Within the next five (5) years, we will be the lead bank or lead arranger in this kind of lending 


\section{CONCLUSION}

Jamuna Bank Ltd. is a commercial bank launched its operation in 2001. It has already developed goodwill among its clientele by offering its excellent services by different divisions. This success has resulted from the dedication, commitment and dynamic leadership among its management over the periods. The working atmosphere of the Jamuna Bank Limited is very simulating. During the short span of time of its operation, the bank has been successfully to the position itself as a progressive and dynamic financial institution in the country. Credit policy is a very convenient banking tool for the business world. The value of this service is immense. It has gathered such a position in the banking sector that people at developed and also developing counties are very much depended on this service. In Bangladesh credit facilities or loans started to become very attractive in recent periods. But still lots improvements in services and facilities have to be made in this department.

For efficient Management of Credit Risks the Bank emphasizes on building cordial rapport and relationship with the customers to ensure that neither the business nor the business relationship between the Banker and the Customer is hampered in any manner whatsoever. Rather it gives an impetus to enhance the same and improves the standard of Customers service of the Bank. Constant monitoring and supervision of the credit plays a vital role for keeping the credit portfolios out of risk. Bank exerts constant efforts on keeping the existing credits up to the mark through regular follow-up and visiting to the customer that can help the Bank to identify any possibility of default much earlier. Early treatment by taking preventive/ remedial measures might save the accounts from being classified.

The banking industry is extremely competitive and constantly changing. Rival banks are introducing new products and services and taking new measures to manage credit risk. Therefore it becomes mandatory for each market player to know what others are doing. This requires R\&D activities and proactive action to meet challenges.

There is no alternative of providing adequate training to the employees. More credit analysts may be recruited to reduce pressure on existing employees. Workshops may be arranged for employees working in credit department to keep them up-to-date. This will also increase their efficiency.

Credit risk management is an ever evolving subject. Banks must be flexible enough to incorporate any new practice in its credit risk management policy. 


\section{References:}

1. Chowdhury, L.R., A Textbook on Bankers Advances, 2nd Edition, Fair Corporation, Dhaka.

2. Rose, P.S.,Commercial Bank Management, 5th Edition, McGraw -Hill, New York, USA,2002.

3. Bangladesh Bank, Managing Core Risk in Banking: Credit Risk Management, Dhaka, 2013.

4. Bangladesh Bank, Credit Risk Grading Manual, Dhaka, 2012.

5.

6. Jamuna Bank Limited, Credit Operational Manual, Dhaka, 2012.

7. Jamuna Bank Limited, Synopsis of Workshop on Documentation and Legal Aspects in Loan Sanction \& Disbursements held at Bank's Training Institute, 2012.

8. Karim, Md. Enayetul, the Weekly Industry, Vol-146, Issue-44, July 2, Dhaka, 2013.

9. Website: http:// www.jamunabankbd.com), accessed on December 9, 2014.

10. Website: (http:// www.bangladeshbank.org), accessed on December 13, 2014.

11. Basel II Accord, (from http://en.wikipedia.org/wiki/Basel_II), accessed November 23, 2014.

12. Published Document \& Banking manual

- Credit Division Manual of JBL

- Several Booklets from Jamuna Bank Limited

- Other internship reports of JBL

ABC Research Alert, Vol 4, No 1 (2016)

ISSN 2413-5224 